
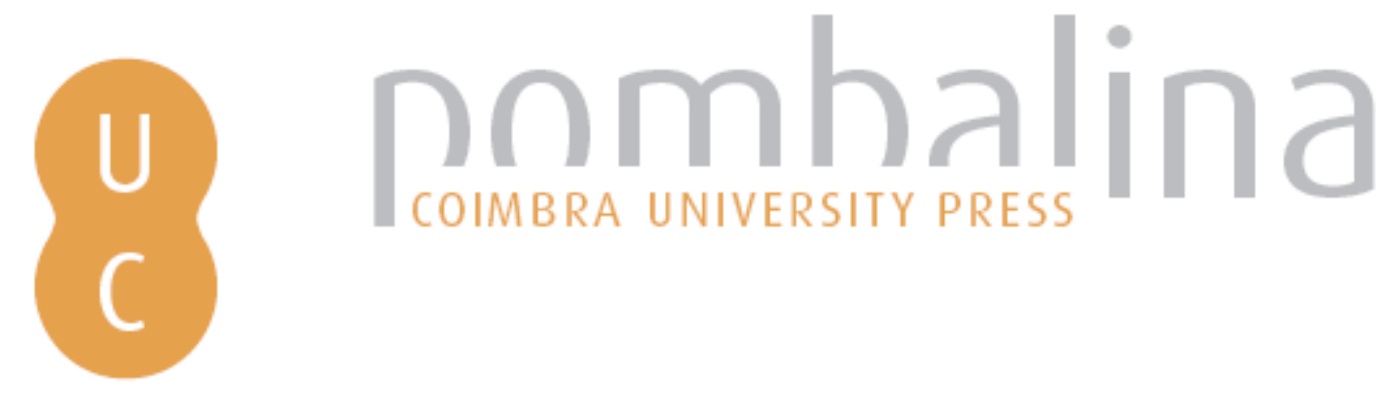

\title{
10 jardim-escola João de Deus: o primeiro dos centenários 1911-2011
}

Autor(es): $\quad$ Rodrigues, Ália; Martins, Ana C.

Publicado por: Centro de Estudos Clássicos e Humanísticos

URL

persistente: URI:http://hdl.handle.net/10316.2/2341

DOI: $\quad$ DOI:http://dx.doi.org/10.14195/978-989-8281-80-7

Accessed : $\quad$ 26-Apr-2023 16:14:34

A navegação consulta e descarregamento dos títulos inseridos nas Bibliotecas Digitais UC Digitalis, UC Pombalina e UC Impactum, pressupõem a aceitação plena e sem reservas dos Termos e Condições de Uso destas Bibliotecas Digitais, disponíveis em https://digitalis.uc.pt/pt-pt/termos.

Conforme exposto nos referidos Termos e Condições de Uso, o descarregamento de títulos de acesso restrito requer uma licença válida de autorização devendo o utilizador aceder ao(s) documento(s) a partir de um endereço de IP da instituição detentora da supramencionada licença.

Ao utilizador é apenas permitido o descarregamento para uso pessoal, pelo que o emprego do(s) título(s) descarregado(s) para outro fim, designadamente comercial, carece de autorização do respetivo autor ou editor da obra.

Na medida em que todas as obras da UC Digitalis se encontram protegidas pelo Código do Direito de Autor e Direitos Conexos e demais legislação aplicável, toda a cópia, parcial ou total, deste documento, nos casos em que é legalmente admitida, deverá conter ou fazer-se acompanhar por este aviso.

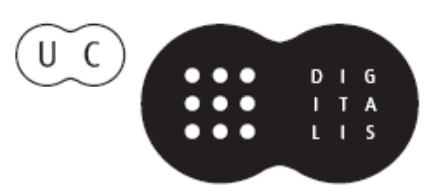


808

$\{$, no

0501

20.55

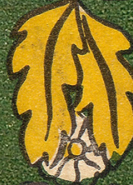

sisura

onjus

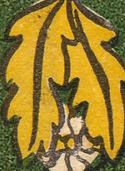

(1)

Dit

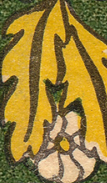

mo nos

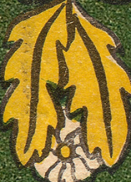

Gotal

onsa

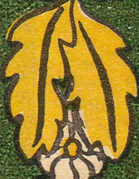

SI

Tar

$3 \int_{104}$

avas
PRTMEIRO J ARDIM ESCOLA JOAO DE DEUS DE COMMBA

5350

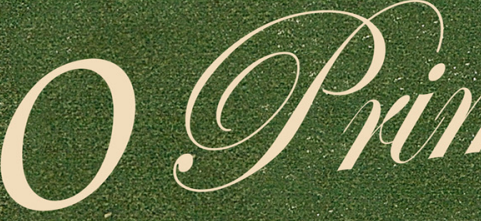

neire dos

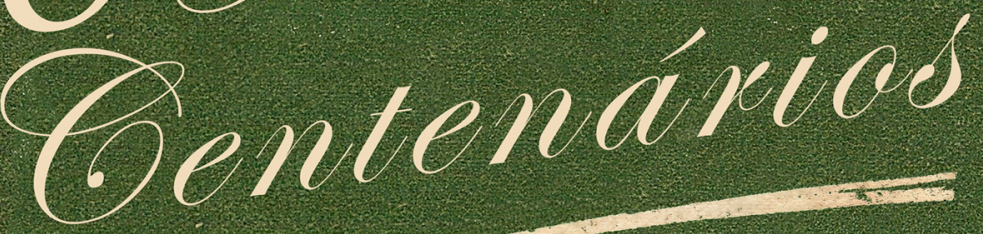

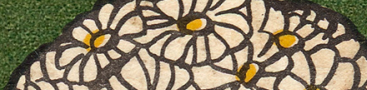

1012 201352

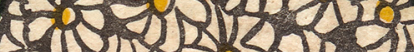

Nectos?

201200200

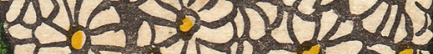

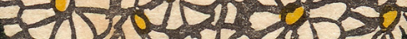

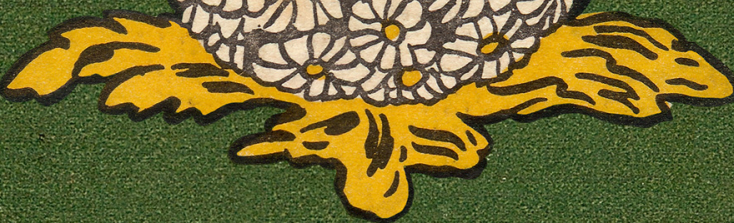

Para gente moça 
(Página deixada propositadamente em branco) 
$1^{\circ}$ JARDIM-ESCOLA JOÃO DE DEUS O PRIMEIRO DOS CENTENÁRIOS 1911-2011

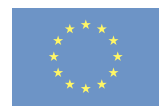




\section{ExPOSIÇÃo}

\section{Comissariado:}

Maria do Céu Fialho, Maria Amélia Saraiva e António M. Vilhena

\section{CONCEPÇÃo do PROJECTO:}

ARCO - ARQUITECTOS

Centro de Estudos Clássicos e Humanísticos

Argumento:

Ália Rodrigues e Ana C. Martins

EDIÇÃo TÉCNICA:

Fernando Madeira, Teresa F. Madeira e

Nelson H. S. Ferreira

\section{DocumentaÇão arguivística:}

Museu João de Deus Bibliográfico, Pedagógico e Artístico

$1^{\circ}$ Jardim-Escola João de Deus - Coimbra

Biblioteca Geral da Universidade de Coimbra

\section{Apoio À estrutura:}

$1^{\circ}$ Jardim-Escola João de Deus - Coimbra

Casa Municipal da Cultura de Coimbra

Centro de Estudos Clássicos e Humanísticos

\section{Sonoplastia:}

Sansão Coelho

\section{Fotografia:}

Fernando Madeira, Vitor Madeira e Jorge

Eliseu

\section{MONTAGEM E IMPRESSÃO:}

3D LAB - COMUNICAÇÃO E GESTÃO DE IMAGEM

\section{Seguradora:}

Empremédia - Global Seguros

\section{Catálogo}

Autores: Ália Rodrigues e Ana C. Martins

Título: $1^{\circ}$ Jardim-Escola João de Deus. O Primeiro dos Centenários 1911-2011

EDrToR: Centro de Estudos Clássicos e

Humanísticos

EDIÇÃO: $1^{a} / 2011$

Coordenação Científica: Maria do Céu Fialho e Maria Amélia Saraiva

CONCEPÇÃo GRÁfICA E PAGINAÇão DO E-BOOK:

Nelson H. S. Ferreira

Design Gráfico e projecto do modelo:

Fernando Madeira e Nelson H. S. Ferreira

Fotografia: Fernando Madeira, Vitor Madeira e Jorge Eliseu

Obra realizada no âmbito das actividades da UI\&D Centro de Estudos Clássicos e Humanísticos

ISBN: 978-989-8281-79-1

ISBN DigITAL: 978-989-8281-80-7

Depóstto Legal:

Obra Publicada COM o APOIO de:

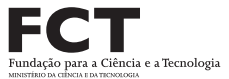

$\mathrm{POCI} / 2010$
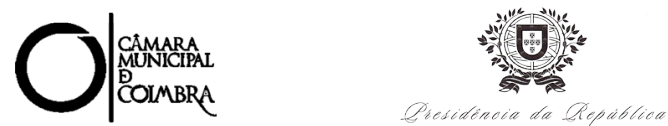

(C) Centro de Estudos Clássicos e Humanísticos da Universidade de Coimbra

Reservados todos os direitos. Nos termos legais fica expressamente proibida a reprodução total ou parcial por qualquer meio, em papel ou em edição electrónica, sem autorização expressa dos titulares dos direitos. 


\section{ÍNDICE}

O primeiro Jardim-Escola João de Deus de CoImbra - uma EsCola nova de 100 anos 7 António Ponces de Carvalho

Palavras para LeR

Maria José Azevedo Santos

EducAR PARA A CIDAdANIA. UM PROJECTO MILENAR COM OS OLHOS NO FUTURO

Maria do Céu Fialho

PARTE I

ENQUADRAMENTO POLÍTICO E PEDAGÓGICO

PARTE II

O Método João de Deus: o Processo de Ensino APREndizagem na ARTE DA LEITURA

PARTE III

$1^{\circ}$ Jardim-Escola João de Deus: Projecto inacabado

Bibliografia

A OrganizaÇÃo 
Eu posso ser homem sem saber retórica; o que não posso é ser verdadeiramente homem sem saber ler.

Sou a imagem de Deus, mas não sou a sua semelhança; não estou em toda a parte, cercam-me o espaço e o tempo; não converso com os mortos, nem falo com os vindouros; não conheço os negócios da minha Pátria.

João de Deus (1830-1896) 


\section{O primeiro Jardim-Escola JoÃo De Deus de CoImbra \\ - UMA ESCOLA NOVA DE 100 ANOS}

A menina Eugénia, um ano, caiu de cama no princípio da primavera. A Cartilha Maternal foi a pedra angular que o poeta João de Deus ofereceu à Nação, para que os portugueses tivessem a possibilidade de aprender facilmente a ler e compreender o que mais belo e nobre os nossos escritores e poetas puderem transmitir adquirindo uma "ferramenta" fundamental para uma adequada inserção social e o sucesso na vida.

O filho, João de Deus Ramos, ciente que "uma boa educação tem de ser eminentemente nacional", criou, como ele tantas vezes afirmou, os seus "poemas de pedra e cal" - os Jardins-Escolas João de Deus.

O primeiro nasceu na cidade berço da Educação em Portugal - Coimbra. Esta escola criada e construída da raiz é a mais antiga escola infantil de Portugal e foi a primeira concretização de um projecto educativo inovador, que visa ajudar as crianças a adquirirem as capacidades, destrezas, habilidades, conhecimentos, valores e atitudes necessários.

O sonho de João de Deus Ramos de ajudar, através da educação, à promoção e desenvolvimento de cada criança, permitindo-lhe atingir patamares mais elevados, e desta forma contribuir para a melhoria do País continua vivo e é actualizado e adaptado às novas realidades, nos 50 centros educativos da Associação, pelos seus 1209 competentes e dedicados colaboradores.

O Presidente da Associação de Jardins-Escolas João de Deus

António de Deus Ramos Ponces de Carvalho 



\section{Palavras PaRa LeR}

Quem como nós, há muito tempo, elegeu para preferencial área de investigação académica e científica, a histórica da ars legendi e da ars scribendi, o mesmo é dizer, o estudo das técnicas e do saber ler e escrever, na Idade Média, tem um muito especial gosto em responder ao amável convite que nos foi endereçado pela Exm. ${ }^{\text {a }}$ Senhora Directora do $1^{\circ}$ Jardim-Escola João de Deus de Coimbra fundado, no dia 2 de Abril, de 1911.

Entre as múltiplas iniciativas que enformam o excelente programa de comemoração de "O Primeiro dos Centenários", numa expressão de belo recorte literário, salientamos a Exposição, de que este Catálogo guardará a lembrança para além da efémera mostra de objectos e documentos, criteriosamente organizada e oferecida ao público, na Galeria Pinho Dinis, na Casa Municipal da Cultura de Coimbra.

É como percorrer um elogio à leitura e à escrita através da vida e da doutrina criado no século XIX por um dos mais ilustres poeta e pedagogo português, João de Deus, e continuada por seu filho João de Deus Ramos. Com uma visão extraordinária reconheceu que o método pedagógico que lhe cabia em herança só teria valor através da aprendizagem na escola, ou melhor, no jardim-escola. Numa sociedade cuja informação e a comunicação eram, fundamentalmente, feitas pela voz, pela oralidade, a acção de João de Deus Ramos pode e deve considerar-se revolucionária. Ao fundar, em Coimbra, o $1^{\circ}$ Jardim-Escola, cujo modelo foi até hoje reproduzido por várias dezenas, cumpria o preceito democrático difundido por seu pai: "É preciso que o povo saiba ler e escrever, é preciso motivar os políticos para a execução desses princípios.” Ao longo dos séculos, não faltaram filósofos, antropólogos, sociólogos dedicados ao estudo da alfabetização. A ordem imperativa mantém-se: é preciso ler, ler livros, jornais, cartas. Diz-se mesmo que uma sociedade pode existir sem a escrita mas nenhuma pode existir sem a leitura. A nosso ver, a posse destas capacidades, sendo certo que a leitura precede e pode viver sem a escrita, é complementar e decisiva para a formação e transmissão da memória. A leitura tem uma sedução singular que cada um guarda para si. Lê-se em silêncio, em voz alta, sentado ou deitado no chão, com os pés enganchados como as crianças, em viagem, na praia, na biblioteca ou no quarto de dormir. O leitor enquanto tal, é o ser mais livre que conhecemos. Com um livro na mão só depende de si próprio. Que amargura sentimos ao saber que no Século XXI essa capacidade, essa liberdade, esse poder, é negada ainda a milhões de 
crianças, homens e mulheres. Seres que nunca poderão compreender o mundo todo, porque o domínio das letras é necessário. Seres que jamais vão conhecer o sabor da paixão pela leitura que alimenta a imaginação, o sonho, a inteligência. Seres impossibilitados de viver, nas palavras do insigne Professor Aníbal Pinto de Castro, " a incomparável beleza do livro impresso cuja vista e cujo prazer táctil nenhum CD-Rom jamais poderá substituir aos olhos e aos dedos humanos".

A Vice-presidente da Câmara Municipal de Coimbra Maria José Azevedo Santos 


\section{EDUCAR PARA A CIDADANIA. \\ UM PROJECTO MILENAR COM OS OLHOS NO FUTURO.}

Quando trilhamos os caminhos da lusofonia, quando trilhamos os caminhos de uma Europa de línguas românicas ou da Ibero-américa percebemos que as línguas nos aproximam, ainda que na diversidade de caminhos culturais que, do velho mundo, ao novo mundo apontam. Num segundo momento ganhamos consciência de que este prodígio radica em tempos antigos e na admirável visão que os Romanos tiveram de como manter coeso o espaço por onde se expandiram. Construída uma bem planificada rede viária, cujo traçado as nossas vias internacionais ainda seguem, e que é condição necessária de comunicação, um outro tipo de comunicação se impunha - aquela que uma língua comum, aprendida com as primeiras letras, propicia. Já do séc. I a. C. há testemunhos dessa preocupação em assegurar uma rede escolar que cobrisse as províncias e que permitisse aos povos autóctones, em processo de romanização, o acesso de seus filhos à escola. Do tempo do general Sertório, e da sua acção na Península Ibérica, nos relata Plutarco (Vida de Sertório, 14.3-4, trad. de M. H. Rocha Pereira): "contratou mestres de letras gregas e romanas...e mandava-os ensinar (aos filhos dos Turdetanos, povo da Ibéria), a fim de que, quando fossem homens, participassem na administração e no poder. Os pais sentiam um prazer espantoso, ao verem os filhos irem à escola tão bem vestidos, com as suas togas bordadas, e Sertório a pagar as respectivas custas, a mandá-los muitas vezes fazer exames, a conceder prémios aos que os mereciam...".

Este relato sublinha já, no ancestral ensino, a adequação da matéria ensinada ao meio e à realidade da comunidade, a utilização de vestuário não-discriminatório (precursor do actual bibe), o reconhecimento e estímulo do mérito pela avaliação e pelo prémio. O pressuposto da aposta no ensino é óbvio: jovens alfabetizados e letrados prometem cidadãos mais competentes e conscientes no exercício da cidadania. Esta visão esclarecida é, também, responsável pela criação de uma comunidade de línguas românicas, determinante da face do mundo actual.

João de Deus, o poeta visionário, embebido de ideais de liberdade igualitária e de fraternidade, que decorrem de princípios e ideais irreversíveis que a Revolução Francesa veio impor (Revolução que, em aspectos vários, actualizou a Res publica romana animada de uma coloração democrática grega), entendeu lucidamente essa fórmula: a literacia, partida da atenção ao mundo que rodeia a criança em aprendizagem, forma futuros cidadãos, capazes de exercer a cidadania e afirmar o dever de tolerância e o direito a uma fraterna igualdade num mundo mais justo. 
Esta foi a revolução que preconizou, com a concepção do seu método, num país fortemente marcado pelas trevas do analfabetismo. Os alvores da República conheceram, com seu filho, João de Deus Ramos, o primeiro Jardim-Escola de uma vasta rede que iria repetir, como num ritual de presentificação, o gesto cunhado no subconsciente da memória das raízes. Novos tempos, métodos originais. A espantosa prova de eficácia e reconhecimento do método fez com que a rede escolar se tornasse realidade e que a cartilha transbordasse, em milhares de edições, pelo espaço lusófono. Eis um admirável factor de sedimentação identitária entre os que partilham a mesma língua, ainda que na sua diversidade!

Estão expostas as boas razões para que o $1^{\circ}$ Jardim-Escola João de Deus, de Coimbra, e o Centro de Estudos Clássicos e Humanísticos da Universidade de Coimbra lançassem mãos, em organização conjunta, à celebração do "Primeiro dos Centenários" através da exposição e respectivo catálogo: educar para a cidadania, desde o século I a. C. até ao "Primeiro dos Centenários" deste Jardim-Escola, desde o passado cultural em que nascemos, até ao futuro que se nos abre e rumo ao qual vivemos, ensinando, com a mesma esperança de Sertório: que as crianças de hoje sejam os melhores dos cidadãos da sociedade justa, igualitária e tolerante de amanhã.

Cumpre-nos deixar aqui registado, antes de mais, o nosso agradecimento ao Sr. Dr. António Ponces de Carvalho, às Sr.as D. Ernestina Brito Santos, D. Elsa Gonçalves Rodrigues, D. Ana Maria Virtuoso, bem como ao Sr. Filipe Neves Branco. Manifestamos a nossa gratidão à Câmara Municipal de Coimbra, nas pessoas do seu Presidente, Dr. João Paulo Barbosa de Melo, da Vice Presidente Prof. Doutora Maria José Azevedo Santos, à Casa da Cultura, à Universidade de Coimbra, à Associação de Jardins-Escolas João de Deus, ao Jardim-Escola João de Deus da Estrela, à Revista Artes e Letras, ao Diário de Coimbra, a Eliseus Fotografia. Bem haja o Prof. Doutor Victor Madeira, pela sua disponibilidade, o Sr. Dr. Sansão Coelho, pelas excelentes gravações feitas. Uma palavra final de profundo reconhecimento vai para a equipa cujo entusiasmo, espírito de abnegação, criatividade tornaram possível a vinda à luz do catálogo e a concepção e montagem da exposição: os Arquitectos Fernando Manuel Madeira e Teresa Margarida Fonseca Madeira, os Drs. Ália Rodrigues, Ana Isabel Martins, Nelson Henrique Ferreira. Sacrificando o seu trabalho profissional ou a investigação conducente à escrita das suas teses de Doutoramento ou Mestrado souberam, com generosidade e estoicismo exemplar, sacrificar o particular ao interesse da celebração do ensino e da cultura, num gesto de cidadania afirmada.

Em nome do Comissariado

Maria do Céu Fialho Coordenadora Científica do Centro de Estudos Clássicos e Humanísticos 


\section{Parte I}

ENQUADRAMENTO POLÍTICO E PEDAGóGico 



\section{BREVE REFERÊNCIA À SITUAÇÃo DO ENSINO PRIMÁRIO no Portugal finissecular}

Na transição do século XIX para o XX, do sentimento pessimista finissecular emergiam propostas intelectuais com promessas regeneradoras da sociedade, assentes na edificação de um homem novo. Uma educação generalizada surgia como o instrumento decisivo para alcançar a almejada transformação social, aparecendo como prioridade nos discursos dos vários quadrantes, desde o laico, maçónico e anticlerical, ao monárquico e católico.

Desde o Decreto de Marquês de Pombal (6 de Novembro de 1772), “uma das primeiras tentativas em todo o mundo de organizar a educação primária por conta do Estado" (Oliveira Marques, 1981, p.126), que as reformas educativas $(1820,1826,1835,1844,1870)$ se sucediam, apresentando poucos resultados devido à falta de permanência e consolidação das políticas, fosse pela instabilidade governativa, pela falta de investimento humano e financeiro, pela ineficácia do Conselho Superior de Instrução Pública (1835), de Ministérios de Instrução Pública $(1870,1890)$ ou ainda pela ausência de um método eficaz (Simões Raposo, 1877 apud J. de Deus, 1881). Em 1907, o Director-Geral da Instrução Primária declara: "é-nos impossível ter uma obra de instrução primária, pela razão óbvia de que não temos dinheiro para pagar, sobretudo se confrontarmos as despesas que países como a Suíça, a Bélgica, a Holanda e a Suécia fazem anualmente com o ensino primário”. Apesar disso, este debate teve o efeito de criar uma consciência educativa e colocar a educação na linha da frente dos programas políticos, conforme reforça J. Franco (2009, p. 15): “A educação prepondera e torna-se moda como tema de discurso. As diferentes correntes ideológicas fazem da educação tema dos discursos utópicos".

Perante a insuficiente aposta do Estado numa política de alfabetização, diversos intelectuais e pedagogos empenharam-se na concretização de projectos pedagógicos, como António Feliciano de Castilho, António da Costa, Adolfo Coelho, Oliveira Martins, João de Deus ou João de Barros. O poeta João de Deus deu, com efeito, o contributo mais significativo para a renovação dos métodos tradicionais do ensino das primeiras letras em Portugal, tendo sido largamente aceite no Brasil e Angola. O seu método despertou ainda o interesse de filólogos espanhóis e franceses, tendo sido adaptado para o espanhol e para o francês por Joaquim Sama (1879, Madrid) e, no segundo 
caso, pelo filho do poeta (1920) e pelo maior lusófilo francês, Philéas Lebesgue (vide C. Varela Chá-Chá, 2009, pp. 78-79). 


\section{João de Deus, poeta educador \\ (1830-1896)}

Quando eu ontem passei pelas estradas Surgiu-me em frente aos pulos um pequeno

Olhos grandes e negros bem moreno Curta jaqueta e calças remendadas.

"Donde é que vens, rapaz?"- disse eu - Boiadas Passam ao longe no horizonte ameno $E$ a aragem leve já beijando o feno, Bebia o Sol às águas abrasadas.

- Deus o salve, senhor! Agora eu venho Do colégio e já que o vejo tenho A pedir-lhe um favor, se the aprouver...

E, fitando-me, erecto e com vaidade: - Como à festa não vou lá na cidade.

Diga a João de Deus que já sei ler!” Guilherme de Santa-Rita em homenagem a João de Deus (1895) apud M. Azevedo (1997, p.30 )

Oriundo de S. Bartolomeu de Messines, entrou para o seminário mas cedo o abandonou. Começou a frequentar o curso de Direito em Coimbra no ano de 1849 , terminando a sua formatura dez anos mais tarde. Dizia Antero de Quental a Camilo Castelo Branco: "se visses João de Deus amava-lo, se o ouvisses, adoravalo” (M. da Luz de Deus Ramos, 1997, p. 37). Eugénio de Castro (1869-1944) também com ele conviveu - sobretudo entre 1891 e 1894 - relação de amizade comprovada pelo elogio que o poeta simbolista lhe dedicou: "tem uma alma das mais belas que Deus tem criado, e que Deus amava tanto, que até o seu nome lhe deu.". Durante o curso cultivou amizades com colegas que viriam a ser seus amigos ao longo da vida, entre os quais, o já mencionado Antero de Quental, Teófilo Braga, António de Azevedo Castelo Branco, Alberto Sampaio, Santos Valente, Severino de Azevedo, Francisco Machado de Faria e Maia, Rodrigo Veloso, Alberto Teles e João de Sousa Vilhena. 


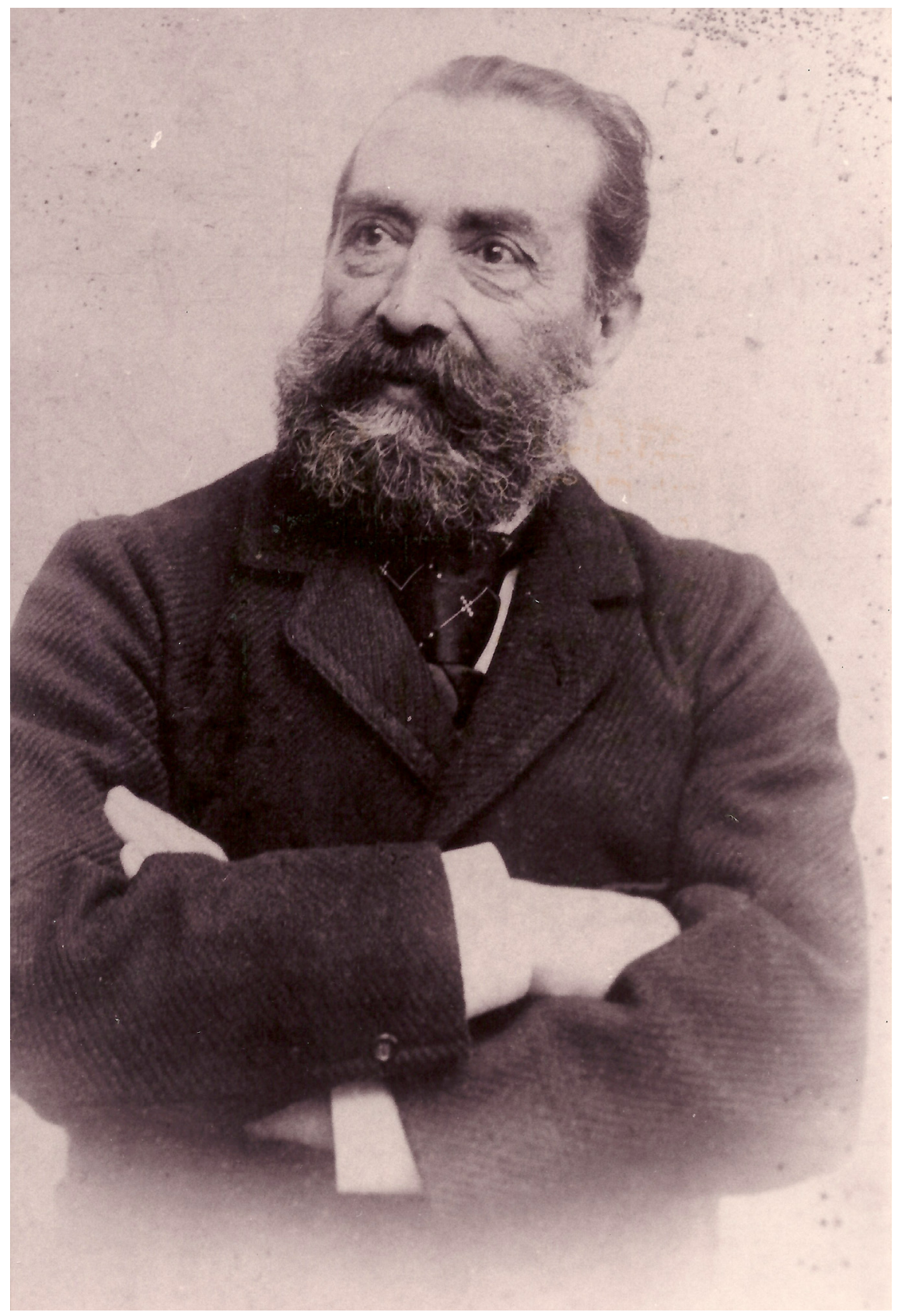


A 13 de Julho de 1859 terminou o curso e decidiu permanecer em Coimbra, colaborando com os jornais: Estreia Litteraria, Atheneu, Preludios Litterarios, Academico, Instituto, Phosphoro e Tira-Teimas e traduziu obras do francês para o português. Publicou o seu primeiro texto na revista académica em 1855 , as suas poesias ganharam fama no meio académico de tal modo que "a publicação das suas poesias gerou entre os estudantes uma espécie de culto” (João de Deus, 1982, p.9). Em 1862, parte para o Alentejo onde colaborou na redacção dos jornais O Bejense (Beja) e A Folha do Sul (Évora), e aí permanece dois anos. Não queria que lhe pagassem um salário fixo, bastava que lhe pagassem as despesas e o tabaco. Desde estudante, tinha o hábito de fazer as viagens a pé, pernoitando em casa de quem lhe desse guaridae, como sinal de reconhecimento oferecia poesias e desenhos feitos por ele a quem o acolhia. Em favor da liberdade de espírito, recusava qualquer espécie de alienação, renunciando inclusive ao dinheiro, evitando qualquer acumulação desnecessária.

Data provavelmente do ano 1869 a sua primeira colectânea de poesia lírica e satírica, Flores do Campo, coligida por J. A. Garcia Blanco. Nesse mesmo ano é ainda publicada uma recolha de catorze poema intitulada Ramo de flores. Em 1869, é também eleito deputado por Silves, fixando-se, por isso, em Lisboa. Contudo, a ribalta política não o atraía. Na mesma cidade, casou com Guilhermina Battaglia e tiveram quatro filhos, entre eles João de Deus Ramos, que haveria de concretizar o sonho paterno: educar para a cidadania e para a liberdade. No dia 8 de Março de 1895 , no dia do seu $65^{\circ}$ aniversário, foi agraciado pelo rei D. Carlos com a condecoração Grã Cruz de Santiago. O rei tomou a iniciativa de ir pessoalmente a sua casa entregá-la, dado que João de Deus se encontrava debilitado devido à sua doença. Nesse mesmo dia, juntaram-se no Rossio vários jovens, foi-lhe feita uma homenagem de gratidão e apreço organizada pelos estudantes de Lisboa e outras associações estudantis que se quiseram associar, vindas do Porto, Coimbra e Santarém. Emocionado, João de Deus abriu a janela e declamou:

Que vindes cá fazer, oh mocidade?

Despedir-vos de mim? Quanto vos devo!

Também levo de vós muita saudade

E em lá chegando à outra vida...escrevo.

Estas honras, este culto

Bem se podiam prestar a homens

De maior vulto

Mas a mim, poeta inculto 
Espontâneo e popular

É deveras singular

(João de Deus, Campo de Flores, 1982, pp. 279-280)

Em 1896, a "nação fez-lhe funerais nacionais com a França a Vítor Hugo." (M. da Luz de Deus Ramos, 1962, p. 4) e de novo a sociedade se reúne, desde "associações, imprensa nacional, clubes, bombeiros voluntários, cooperativas, estudantes de todas as partes e, em sinal de luto, fecharam-se escolas e algum comércio, embaixadas e delegações e colocaram a bandeira a meia aste." (C. Varela Chá-Chá, 2009, p. 53).

O centenário do seu nascimento foi assinalado com várias solenidades: em Faro, foi inaugurado um busto em sua memória e, em Lisboa, a Câmara Municipal na sua antiga casa afixou o texto elaborado por Afonso Lopes Vieira: "Nesta casa morreu João de Deus/aos 11 de Janeiro de 1896/começando a viver para a imortalidade dos grande poetas/ e das almas belas" (J. de Deus, 1990, p. 8).

A 1 de Dezembro de 1966, o seu corpo foi trasladado para o Panteão Nacional. Depois do centenário do nascimento, também o centenário da sua morte foi assinalado em 1996 pelos vários Jardins-Escolas em todo o país. 


\section{NOTA SOBRE A OBRA LITERÁRIA}

Apesar da sua fidelidade à tradição romântica, João de Deus sempre foi considerado um dos rapazes da Questão Coimbrã, tendo partilhado das inquietações espirituais e sociais que marcaram aquela geração. Do ponto de vista literário, João de Deus é herdeiro da tradição romântica, já que tanto temas como certas atitudes de espírito aproximam-no mais dos românticos do que dos seus coetâneos, tendência que garantiu a admiração de M. António Canini (apud J. de Deus Ramos, 1902, p. VII) que o considerou: "o primeiro poeta do amor não só de Portugal mas em toda a Europa no século XIX.” Alguns dos temas predominantes na sua produção poética são o amor da Mulher, a ênfase do aspecto religioso que se traduz numa adesão aos valores mais genuínos do Cristianismo: a pobreza em espírito, a humildade, a devoção à Virgem Mãe. O poeta intitulava-se como "bardo", “cantor popular”, dimensão que não passou despercebida a Eça de Queirós quando afirmou: "João de Deus da Alma Poética do povo português"(João de Deus, 2002, p.5).

Além dos referidos temas, são recorrentes outros relativos à esfera infantil e sociológica como o abandono infantil, a mãe zelosa, o analfabetismo, a pobreza, a indiferença e repressão sociais, a escravidão, entre outros (vide C. Varela CháChá, 2009, p. 55). Com efeito, a dimensão social das gentes e a atenção dedicada à criança e respectivo contex to são o reflexo poético da profunda convicção que só os valores como a igualdade, a fraternidade e o amor ao semelhante podem gerar o progresso humano.

A obra lírica deste poeta foi inicialmente publicada em três volumes muito incompletos: Flores do Campo [1869], Ramo de Flores (1869) e Folhas Soltas (1876), tendo sido reunida em 1893 por Teófilo Braga num volume intitulado Campo de Flores, que lhe dedica ainda um texto introdutório: "o poeta repelia todo o título, toda a palavra ou frase quando não tinham a simplicidade popular. Nisto residia a sua estética plena.” (apud João de Deus, 2002, p.9) A obra deste poeta conheceu várias traduções em língua italiana e, em 1930, Guido Batteli compila estas traduções sob o nome Le Liriche di João de Deus publicada numa separata da revista Biblos (H. Coelho, 2010, pp. 21, 116). É de destacar a sua actividade enquanto fabulista pois, tendo recuperado antigas histórias clássicas, enriqueceuas com recursos estilísticos (aliterações, onomatopeias, etc.), conferindo-lhe grande densidade dramática, eis alguns exemplos: A cigarra e a formiga, A águia e corvo, $O$ leão moribundo que são actualmente dramatizadas nas sessões de expressão dramática nos Jardins-Escolas. 


\section{Campo de Flores}

Ilustrado con desentos originais do Poeld

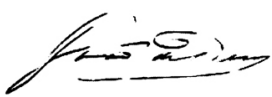

Associação de Jardins-Escola João de Deus

\section{JOÃO DE DEUS}

L' Homme. le Poète et le Penseur 


\section{Cartilha Maternal (1877), uma arquitectura nova}

As sementes do bem e do mal, quem as lança ao mundo quase todas são as mães e os mestres. Ambroise Rendu (epígrafe da Cartilha Maternal, 1877)

Na segunda metade do séc. XIX são divulgados dois métodos para o ensino primário: o Método Português de António Feliciano de Castilho e a Cartilha Maternal de João de Deus, ambos poetas. Até então o método usado era "alfabético, em que se estudavam simultaneamente, e pela respectiva ordem, todas as letras do alfabeto seguidas de sílabas sem sentido que se memorizavam penosamente" (Rómulo de Carvalho, 1981, p. 607). $\mathrm{Na}$ década de 50 foi aplicado o método de Castilho para ensinar a ler e a escrever em pouco tempo (vinte lições) e combater o analfabetismo. Em 1853, Castilho era nomeado “Comissário Geral do Ensino Repentino” (C. Varela Chá-Chá, 2009, p. 36).

Em 1877, João de Deus publica a Cartilha Maternal ou Arte de Leitura, numa altura em que o número de analfabetos em Portugal era superior a 70\%. Note-se que a publicação da Cartilha foi antecedida por uma fase de experimentação: em primeiro lugar pelo próprio João de Deus, depois pelo seu irmão, António do Espírito Santo Ramos, e pelo Padre Madureira em 1875.

Para garantir um entendimento preciso do método apresentado na Cartilha, o poeta educador oferecia explicações a professores que vinham de todo o país, enviados pelas Câmaras Municipais, além de apresentar, em sua casa, três conferências por semana para este efeito (C. Varela Chá-Chá, 2009, p. 71). O método é assim divulgado e praticado de norte a sul do país, além de ser aplicado em quartéis, fábricas e colégios com o apoio das respectivas Câmaras. A inovação do método proposto por João de Deus consistia no próprio ponto de partida: o estudo da fala. Esta metodologia fundase na língua viva, pois é falando e ouvindo que as crianças conseguem segmentar as palavras que lhes interessam, antes de serem capazes de as empregar em frases.

Seis anos após fundação da Associação das Escolas Móveis pelo Método de João de Deus (1982), o Parlamento declara "nacional o método de Leitura Cartilha Maternal João de Deus", através de uma Carta de Lei datada de 2 de Agosto de 1888, sendo também, o próprio, eleito Comissário Geral do seu método. Em 1892, porém, este cargo de comissário é extinto e já em 1895 é retirado o método João de Deus das escolas de Lisboa e do Porto (Associação de Escolas Móveis pelo Método João de Deus, 1898, p. 11).

No Brasil, porém, é entretanto introduzido o método de João de Deus na Escola Normal de São Paulo em 1883 e, em 1897, o governo de S. Paulo importa vários exemplares da Cartilha Maternal de João de Deus para distribuir nas escolas do estado. Em 1920, João de Deus Ramos traduz a Cartilha Maternal para o francês, conforme nos testemunha Afonso Costa, o fundador do Partido Democrático Português: "É uma honra para Portugal ver traduzido e adaptado para francês o admirável método de leitura $(. .$.$) E é justo que essa tradução e adaptação seja feita pelo filho (...)” (apud M.$ 


\title{
METODO CASTLLHO
}

\author{
PARAO \\ ENSINO RAPIDO E APRASIVEL \\ DO LER IHPRESSO, HANUSCRITO, E NUMERACT̃O
}

obit tos o mos E Do ESCREVER

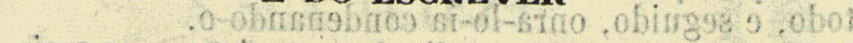

- 8 OBRA TÄ́o PROPRIA PARA AS ESCÓlaS of 20

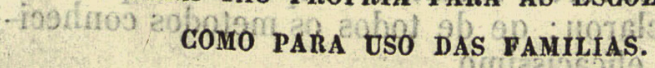

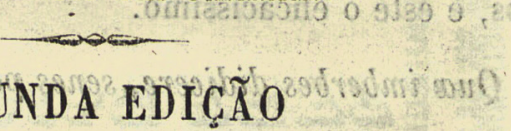

Inteiramente refundida, aumentada, e ornada de um grande numero de vinhetas.

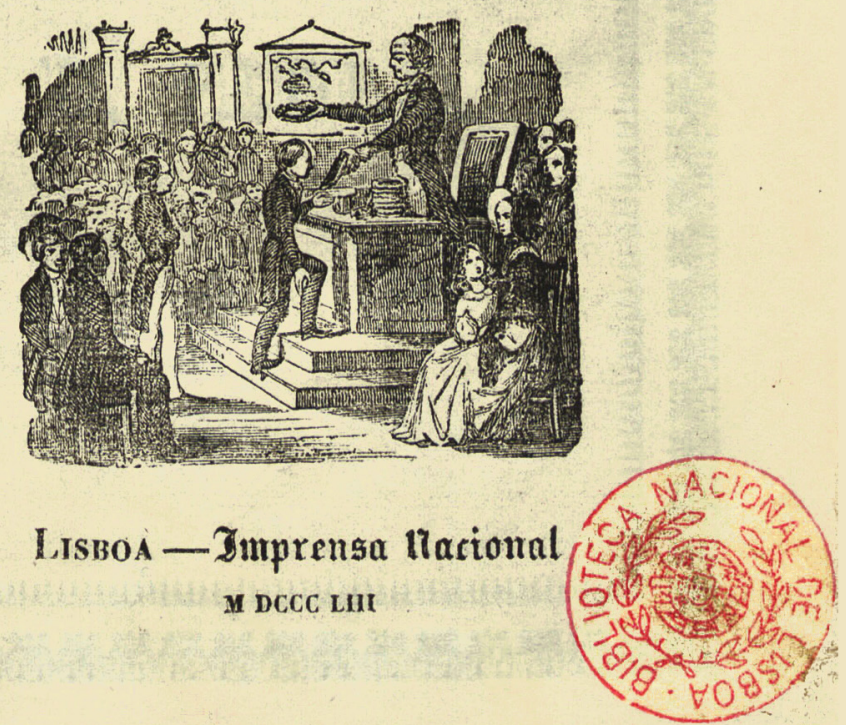




\section{GARTILHA MATERNAL}

\section{$\infty$ \\ ARTE DE LEITURA \\ ${ }^{\circ}$ \\ JOÃO DE DEUS}

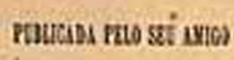

CANDIDO J. A. DE MADUREIRA

ABBADE DE ARCOZELLO

cost

O RETRATO DO AUTOR

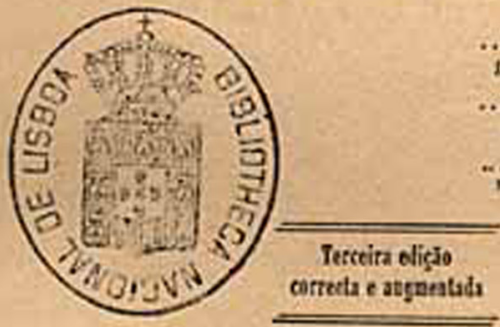

... selestis bova ...

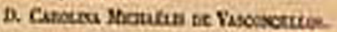

... atilinita posticaglo.

A. Hacius?

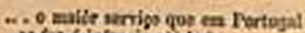

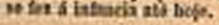
Atcern Conns.

LISBOA

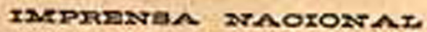

1878 
de Azevedo, 1997, p. 61).

Casimiro Freire, o apóstolo da instrução

Pedem-me que fale sobre o senhor Casimiro Freire. Esse homem não quer nada para si.

Quer tudo para os outros.

Esse homem não só repele como detesta

para ele tudo o que seja publicidade.

França Borges in Jornal Comércio e Indústria nº 175 (1904)

Republicano desde 1862, foi seguramente o primeiro propagandista em Portugal do método João de Deus, tendo suportado financeiramente diversas iniciativas de alfabetização.

Sendo oriundo de uma família humilde, ainda jovem, emigra para Lisboa, onde começa por trabalhar como caixeiro e, fixando-se na capital, enriquece como comerciante e industrial. Nesta cidade, casa com Maria Madalena Battaglia, sogra de João de Deus. O seu combate público contra o analfabetismo data, pelo menos, de 1881, quando publica, no jornal $O$ Século, o artigo "A instrução do povo e a monarquia”, e criticando a negligência dos governos monárquicos, propõe o envio de missões de alfabetização de professores habilitados que ensinassem a ler e a escrever para os lugares mais empobrecidos de Portugal. Desta necessidade brotou a Associação de Escolas Móveis pelo Método de João de Deus, fundada conjuntamente com João de Deus a 18 de Maio de 1882.

Este filantropo garantiu todo o suporte financeiro ao projecto. Cedeu um primeiro andar dos armazéns onde trabalhava (Largo Terreiro do Trigo) para ser a sede desta Associação. Em 1897, um ano após a morte de João de Deus, publica em folheto uma representação à Câmara de Deputados, sob a epígrafe "A Instrução do povo e o método João de Deus". Em 1911 foi o mais votado da Junta Consultiva do Partido Republicano, tendo-se desligado do partido em 1916. Por decreto de 5 de Junho de 1915, o Ministro da Instrução Pública Magalhães Lima incumbiu-o da catalogação e organização do Museu Bibliográfico, Pedagógico e Artístico João de Deus, serviço que concluiu a 30 de Junho de 1916, tendo sido inaugurado no ano seguinte por João de Deus Ramos. Por decreto de 23 de Dezembro de 1916, publicado em 9 de Janeiro de 1917, foi encarregue da guarda e conservação do museu até à sua instalação definitiva junto ao Jardim-Escola João de Deus na Estrela, recebendo por esse serviço a gratificação mensal de $50 \$$. Faleceu a 20 de Outubro de 1918, o seu corpo partiu da estação de comboios do Rossio num fourgon do comboio-correio da noite a caminho Pedrógão Pequeno. A acompanhar o corpo estavam, entre outros amigos íntimos, professores, corpos directivos e pessoal da secretaria da Associação de Escolas Móveis. 


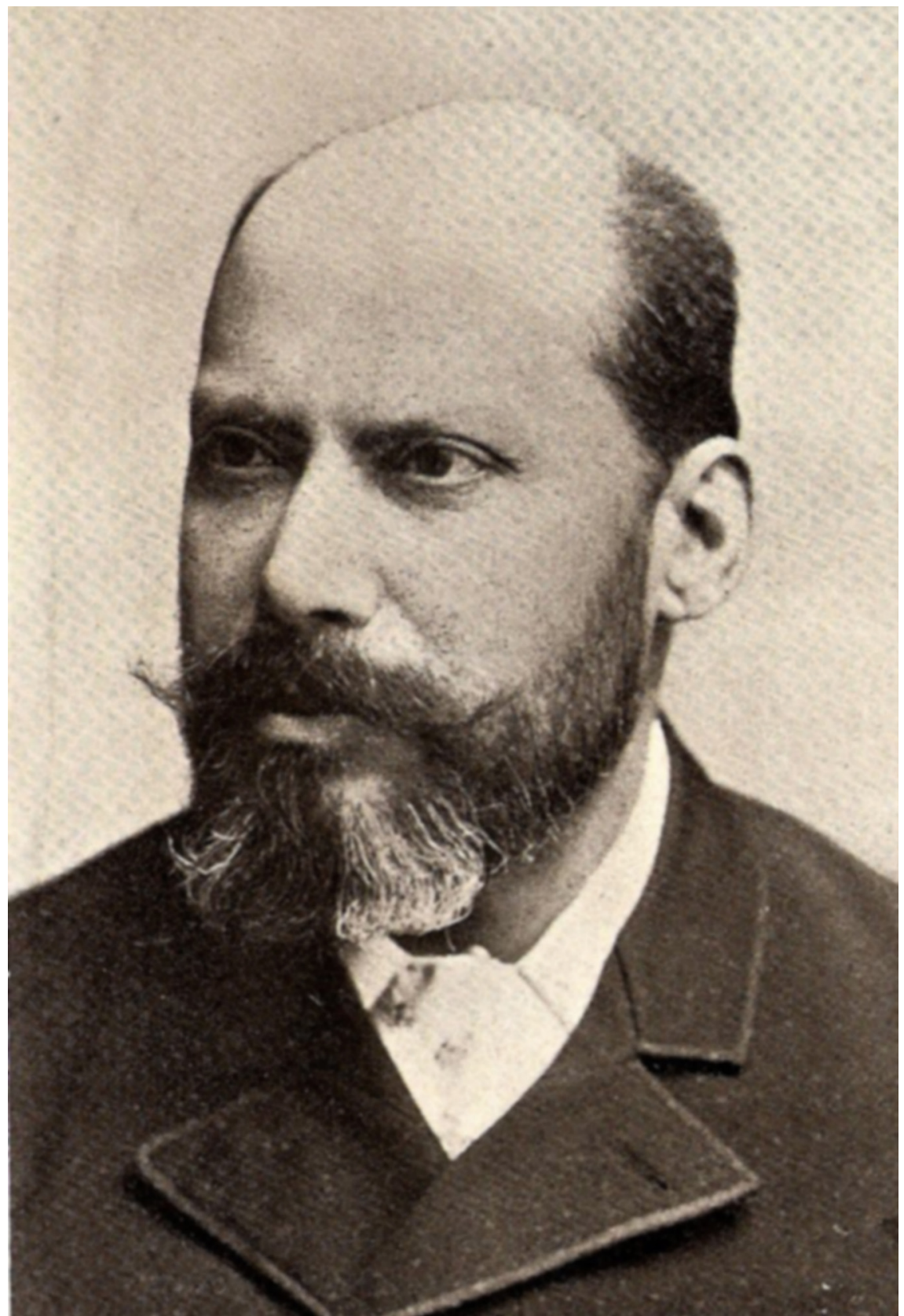

Fig. 6: Casimiro Freire (1843-1918) 


\section{Escolas Móveis, um PROJecto missionário}

A reputação da Cartilha irá crescendo com o tempo; o livro irá penetrando em todas as escolas da cidade, passará às vilas e aldeias, aos lugares e aos casais, enfim, até onde houver uma mãe e um filho (....).

Carolina Michaëlis de Vasconcelos (1976, p. 89)

Fundada no dia 18 de Maio de 1882, a Associação das Escolas Móveis pelo Método de João de Deus deve-se a Casimiro Freire (1843-1918). Este projecto acaba por difundir o método de leitura João de Deus de forma mais eficaz, tendo como objectivo "ensinar a ler, escrever e contar pelo método de admirável rapidez, (...) os indivíduos que o solicitarem, até onde permitam os seus meios económicos, enviando nesse intuito às diversas povoações da nação portuguesa professores devidamente habilitados - não se envolvendo em assuntos políticos, nem quaisquer outros alheios ao seu fim."

No primeiro ano, já se tinham realizado quatro missões - Castanheira de Pêra, Pedrógão Grande, Lisboa, Ramalhos (Sertã) - e uma centena de alunos fora alfabetizada. De 1886 a 1888 já se tinham realizado quarenta missões e foram considerados aptos cerca de 1215 alunos. A Associação realizaria missões em várias localidades do país, ficando quatro meses em cada uma (M. da Luz de Deus Ramos, 1997, pp. 38/40).

Em 1907, tem lugar a fusão entre a Associação de Escolas Móveis e a Associação de Escolas Maternais de que fazia parte Ilda Jorge Bulhão Pato, sobrinha do poeta da Paquita. Em 1908, quando o filho do poeta, João de Deus Ramos, assume a direcção Associação, altera o nome para Associação de Escolas Móveis pelo Método João de Deus e Bibliotecas Ambulantes e Jardins-Escolas. Para ilustrar o sucesso das missões de alfabetização levadas a cabo nesta altura, apresentamos a súmula dos resultados obtidos no ano lectivo de 1911-1912 ao fim de 18 missões escolares no artigo apresentado (figs. 10-11, 12). Uma década mais tarde, já 135.640 crianças tinham sido alfabetizadas pela Associação de Jardins-Escolas João de Deus. Quanto à formação dos professores para estas missões, havia, com efeito, uma grande preocupação, pois não era fácil arranjar professores capazes de compreender o método e que o soubessem expor com clareza e rapidez. Para uniformizar a formação dos educadores, além da Cartilha Maternal, baseavam-se também em Dever dos Filhos da autoria de João de Deus, bem como nos Quadros Parietais, cartões que reproduziam em tamanho grande as lições da Cartilha. Em 1920 iniciou-se o primeiro - e durante largas décadas o único - curso de formação de Educadores de Infância em Portugal, designado Curso de Didáctica Pré-Primária pelo Método João de Deus. 


\section{Durante o Estado Novo}

O Estado Novo, apesar de não apoiar a Associação, concedeu sempre a liberdade pedagógica necessária ao seu crescimento. Conforme testemunha Maria da Luz de Deus Ramos (1998, p. 3-4): "Enquanto o trabalho fosse reconhecidamente bom, nada [Inspecção-Geral] teriam a dizer (...) a Cartilha era um elemento básico. Continuou a ser usada e durante os longos anos do antigo regime, nunca nenhum Inspector o mínimo reparo. O prestígio e o respeito pelo Jardins-Escolas era inegável. Prova-o o número de Jardins-Escolas construído nessa época e a proposta feita a João de Deus Ramos pelo Dr. Carneiro Pacheco:

os Jardins-Escolas João de Deus filiavam-se no Estado Novo e o País, de norte a sul, seria coberto de Jardins-Escolas, bastava colocar nos que fossem sendo construídos, na sua entrada, um dístico - Obra do Estado Novo.

João de Deus recusou. Dizia que as formas de governo passam e a Escola fica, não devendo fazer sofrer às crianças as evoluções caprichosas das paixões políticas. (...) No entanto, mantendo essa independência política continuou a ser dado apoio a novas construções pelo Fundo do Desemprego." Prevaleceu o respeito pelos interesses das crianças. Além disso, acrescenta a neta do poeta João de Deus (1998, p. 5), "Em 1943, João de Deus Ramos cria uma Escola de Educadores de Infância com o nome de Curso de Didáctica Pré-primária pelo Método João de Deus, a primeira a ser fundada em Portugal e que deu um grande impulso à Educação Pré-Escolar.” 


\section{Depois do 25 de AbriL}

A censura foi sentida, pela primeira vez, depois do 25 de Abril, conforme confessou a mesma directora da Associação de Jardins-Escolas João de Deus (1998, p.5): “(...) pela primeira vez uma Inspectora fez um reparo ao uso da Cartilha Maternal, numa época em que se supunha haver liberdade de escolha de Métodos; vários Inspectores alegavam ter instruções para impor retalhar e dividir o salão central, base duma arquitectura própria nos Jardins-Escolas estudadas por João de Deus Ramos que advogava uma arquitectura funcional; (...) Foi-nos feita a imposição de ter uma vigilante por Educadora, erro pedagógico de graves consequências, como facilmente poderá ser aprovado, que encarece o trabalho pedagógico e não vimos nas escolas dos principais países da Europa (...); ouvimos críticas de Inspectores ao nosso imobiliário, a um modelo de carteiras que não há muito tempo encontrámos muito parecidas numa fábrica de mobiliário escolar na Suiça $(\ldots)$.

Assim, com desespero e tristeza depois de uma acção pedagógica de 87 anos restam aos Jardins-Escolas João de Deus três alternativas:

$1^{\circ}$ Fechar os Jardins-Escolas João de Deus, principalmente os de pequenas localidades, deixando de atender alguns milhares de crianças.

$2^{\circ}$ Deixar de dar assistência educativa e social, que incluiu duas refeições diárias, almoço e merenda, às crianças mais desfavorecidas economicamente o que equivaleria a fazer morrer o idealismo solidário dos Jardins-Escolas João de Deus.

Não seriam verdadeiros Jardins-Escolas passariam a ser escolas de elite para crianças privilegiadas!...Não foi para isso que João de Deus Ramos deu a sua vida e se devotou sem nenhum interesse material, aos seus ideais pedagógicos e democráticos. (...)

Resta uma terceira alternativa:

$3^{\circ}$ Que sendo bem examinada a acção benemérita e o sucesso escolar dos Jardins-Escolas João de Deus lhe seja concedida uma Autonomia responsável. (...)

Impor através de regras, um modelo de escola único como se está a verificar actualmente, regras, não baseadas em grande experiência pedagógica, não será democrático nem bom para o País, nem para a Criança portuguesa.”

Apesar de todas estas imposições políticas e dificuldades testemunhadas por Maria da Luz de Deus Ramos, o projecto pedagógico da Associação mais uma 
vez vingou e Maria da Luz de Deus Ramos inaugurou mais nove Jardins-Escolas até ao fim da sua direcção em 1999: Olivais Sul (Lisboa), Santo Tirso (1975); $2^{\circ}$ Jardim-Escola João de Deus em Coimbra; Braga (1984); Faro (1986); Penafiel (1991); Urgeiriça, com valência de creche (1991); Castelo Branco (1992); Ponte de Sôr (1996), entre outras obras de elevado valor para a Associação que serão referidas oportunamente.

Hoje, é reconhecida como Instituição Particular de Solidariedade Social (IPSS) dedicada à Educação e à Cultura, tem 8845 utentes nos 49 Centros Educativos distribuídos pelo país.

Os Jardins-Escolas João de Deus recebem apoio financeiro do Ministério da Educação e do Ministério do Trabalho e da Solidariedade Social. A actividade educativa da Associação reparte-se por: 40 Jardins-Escolas, 6 Centros Infantis e Creche Familiar, 2 Ludotecas Itinerantes (2002, 2003), o Museu João de Deus Bibliográfico, Pedagógico e Artístico, a Casa Museu de Lisboa e a Casa-Museu João de Deus em S. Bartolomeu de Messines, a Escola Superior de Educação João de Deus, o Projecto Anos Ki Ta Manda, o Projecto GIP (Gabinete de Inserção Profissional), o Centro de Acolhimento Temporário de Crianças e Jovens em Risco de Odivelas Casa Rainha Santa Isabel. 


\section{MENÇÕES HONORÍFICAS ATRIBUÍDAS \\ À Associação de Jardins Escolas João de Deus:}

1991 | O Ministro da Educação, Roberto Carneiro, atribuiu à Associação de Jardins-Escola João de Deus uma menção honrosa no grau de Mérito Pedagógico (art. $4^{\circ}, 6^{\circ}$ e $7^{\circ}$. do Decreto-Lei no 288/88, de 23 de Agosto).

1997 | A Organização das Nações Unidas para a Educação, Ciência e Cultura, reunida na sua sede na UNESCO, em Paris, agraciou a Associação de JardinsEscola João de Deus com a Menção de Honra do prémio de alfabetização Noma, destinado a homenagear as Instituições, Organizações ou Pessoas que se tenham distinguido na luta contra o analfabetismo de forma particularmente meritória.

2004 | Prémio «Manus Cais» - 1. ${ }^{\circ}$ prémio na categoria Organizações e Instituições Sociais, com o projecto "Programa ATL Itinerante - Ludotecas João de Deus", correspondente à "Instituição mais Solidária”.

2007 | Alcuin Award - Prémio atribuído às Ludotecas João de Deus pelo seu contributo para a Educação em Portugal pela European Parents AssociationEPA. (Fig. 7)

2007 Prémio Iberoamericano a la excelencia educativa. (Fig. 8)

2008 | Prémio Gulbenkian - O Prémio Gulbenkian Educação. Distinguiu os 126 anos de serviços prestados à Educação e ao Ensino pela Associação de Jardins-Escolas João de Deus. (Fig. 9) 


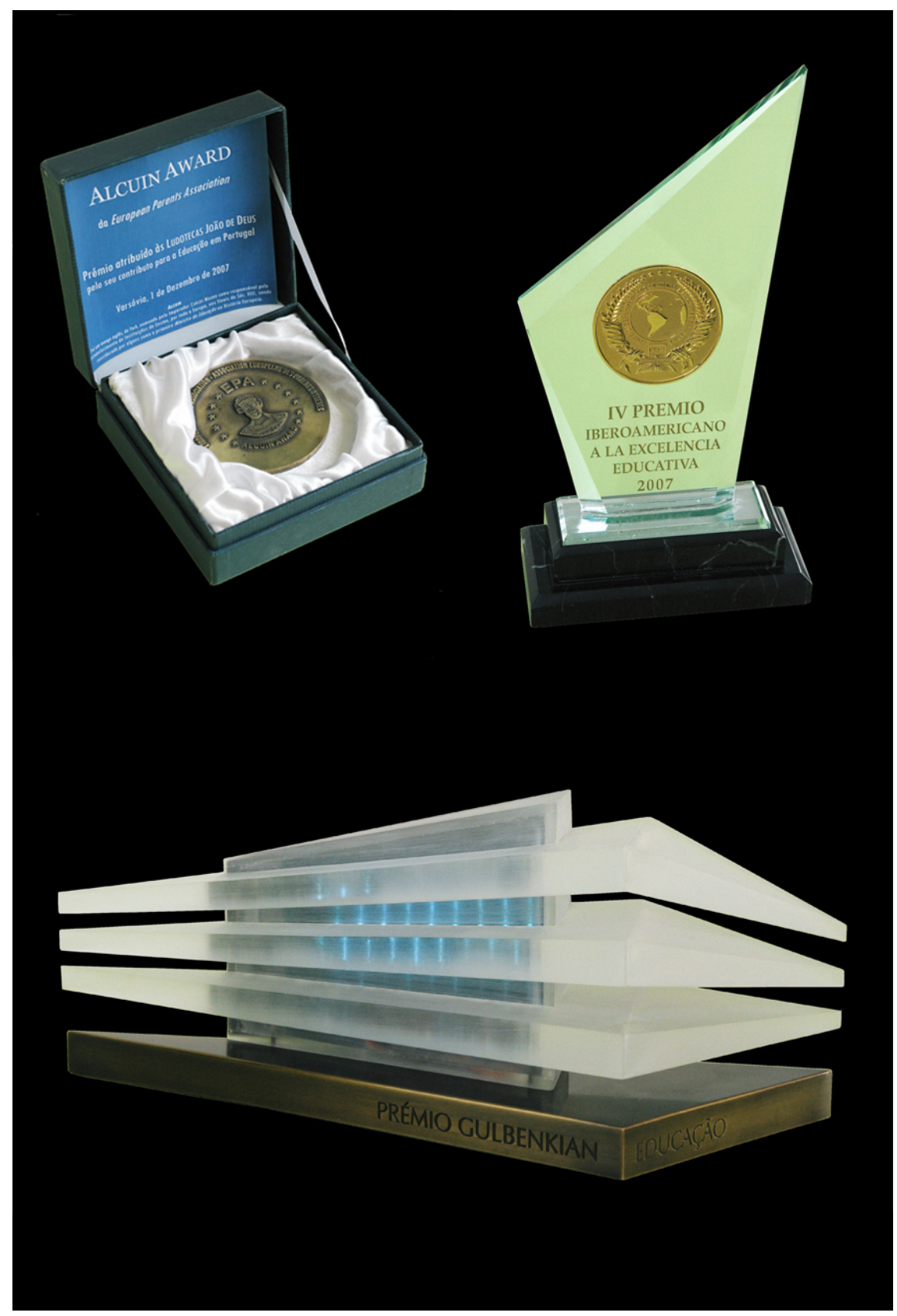




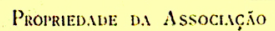
de Escolas Móvis pelo MÉTOno Joío DE Dres.
Composto e impresso por conta do Jistado nia MIPREENSA NACIONAL de LISBOA.

Sede em Lisboa-Rea da Hokta SÉca, 9, 1." (a Praça de Camöes)

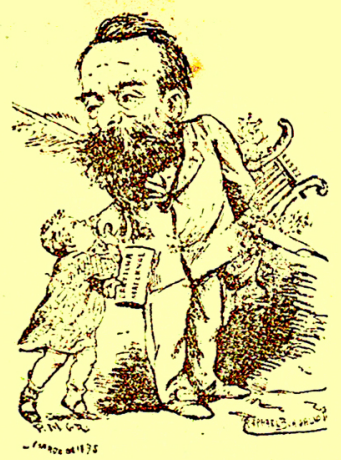

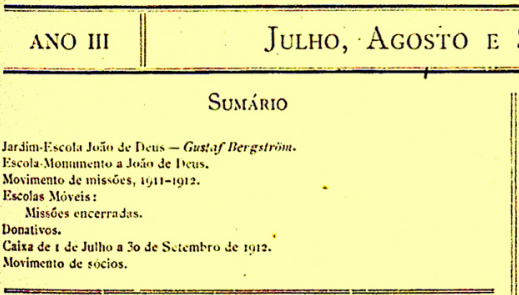

\section{JARDIM-ESCOLA JOÃO DE DEUS}

Neste pequeno pais, onde a etiqueta estrangeira tam frequentemente decora os objectos de uso diario mais banais, onde a arte de copiar ideals estrangeiras ć quísi um sinal ativico carateristico da raça, aparecem, de vez $\mathrm{em}$ quando, arrojadas iniciativas de flagrante originalidade, esboçam-sc obras nacionais de grande vulto $\mathrm{e}$ indiscutivel merito.

IIas a organizada indigència mental permitida, e mais do que permitida, fomentada nos últimos tempos do constitucionalismo, divorciou a alma portuguesa, tam nitidamente entusiasta, de todos os problemas de reabilitaciáo social, e os ollos mais observadores como os espiritos mais penetrantes, nio tinham para qualquer obra, bem nussa, mais do que o sorriso sééptico da mais fria descrenca.

Tratando-se de educação, dava-se o caso estranho de toda a gente a preconizar, como o unico remédio para a depressáo moral de que enfermava o pais e de nunca $o$ aplicar.

Lugar comum conhecido $\mathrm{cm}$ todos os lares, toda a gente feria desapiedadamente o bordão da salvação da Patria pela educação, e aproveitado hábilmente ém belos efeitos de retórica, constituiu por vezes o esqueleto das melhores rajadas tribunicias.

A educaçíio cra o Eldorado com que se faziam aguar os olhos ingénuos do povo, a terra da Promissão com que se alentavam os simples prestes a desanimar, a miragem com que se enervavam para a marcha os sedentos de melhores condiçóes sociais.

Era uma cousa longinqua, dificil de distinguir, indecisa, vaga, mas deliciosa pelo encanto do mistério.

No emtanto, a educaçĩo sera de facto a salvação desta Pitria amada, ou cla nioo teri nenhuma.

O pensamento de João de Deus, chamando Cartilha Maternal a sua arte de leitura, e a amarga ironia do seu soneto:

- Andam a dizer mal aa monarquian...

provam bem que o grande lirico, viu que havia maior necessidade de profilaxia do que de cura, de racina que de remédio.

Imaginando cada máe uma educadora, o pocta dedicou-the a melhor obra da sua vida, essa que rivaliza com os seus mais sentidos versos em beleza de sentimento, mas que os excede muito em alcance social.

Surpreendendo, por uma intuiç̣īo clara, delicadissima, todas as dificuldades que a criança, a pobre mairtir das excolas, encontiave nos seus primeirus passos vacilantes, compôs ésse assombro de lógica e intulçiio,

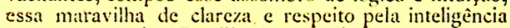
nascente, que é a Cartilha Maternal.

Quebrados os grilhōes da escravidăo da memória, - 'talva iniciada, estara esboçada toda uma arquitectura pedaśógica nova.

A Escola precisava de passar por uma transforma. căo radical, onde a espontaneidade e a simplicidade fossem pedras angulares, e onde o carinho maternal suprisse o castigo corpóreo com todas as vantagens possiveis.

Muitos anos levou a compreender tam simples rerdade; c ainda hoje, que a soluçīo se tornou uma reali. dade, e não existe fí incógnita alguma no problema, pouca gente se interessa com sinceridade pela questäo, ou sequer a compreende claramente.

E por isso que, falar do Jardim-Escola Ioño de Deus, chamar para êle a atençióo dos verdadeiros beneméritos, aponti-lo como modêlo aos próprios Governos, é um dever a que não sabe fugir o signatário, e é tambèm o direito que não aliena um modesto professor.

Eu suponho que o leitor feito turista aceita a camaradagem dèste mau cicerone, e atingido o extremo do Jardim Botânico, onde recheou a carteira de impressivas notas, me pregunta que edificio é èsse que temos em frente, cujo jardin, limitado por um sóbrio gradeamento tem como pontos,cardiais o Colégio Ursulino, onde ensinavam freiras, a direita; o Seminário, onde padres educavam e catequizavam, em frente; um abeesso universitario distante do organismo mác, à esquerda. 
a criança sente dignificarem-se as suas mäozinhas, èsses correctissimos instrumentos produtores de pequenas cousas estéticas que as enlevam e tornam orguhosas das suas capacidades.

Querer ś poder.

Fis um aforismo com cuja filosotia se familiarizam as crianças de tal modo, que vendu executar pela primeira ve\% un novo traballow, sc itrerestam logo a jmiti-lo com ayuela nobre confiam en cm si, yue traz ine. vitavelmente a certezit das primciras vitorias sible as primeiras dificuldades.

Ei assim, convencendo-se cie que, - simbolos de ideals concretas -os nomes de cousas se aprendem conhecendo cousas. o corpo docente indu/ delieadamente at criançit a observar, a preserutar, a exceutar da ma. neira mais simples, as operaţốes psiquicas fundamen. tais : a análise e a sintese.

Numa palas ra, por meio da sugestīo pela persuastio, pelo aplauso sibrio e nobilitante do que ć bem leito ou denotat uma tendencia promessira, encaminham-se lenta mas seguramente, cem firios humanos a sua floracito completi, perfeita, integral.

do iniciar-se novo ino escular, encontra-se coordeniado, sob o titulo modesto de simples experiència! um valsto material pedagógico y̨ue at conisissĩo temtari man. ter equilibtado e perfeito conse o encontrou, e a que a boa vontade de todos os que amam os pequeninos, vendo neles os cidadáos de ankanhia, dara decerto o esclarecido auxilio do seu culto espirito.

to terminar o meu arrigo reparo yue apenas conse. gui esboçar por certos toplicos a obra modelar que \&́ o ardim-Liscoll.

A minha penitencia serai manter silencio até yue aprenda a desenhar com correccio um quadro como éste que pretendi por diante dos seus ollos, camarida leitor. Cumbra, 2.t de Outubro de liniz.

Ciustif Mnotip Barciströn.

\section{ESCOLA-MONUMENTO A JOÃO DE DEUS}

Publicatda a lei pela qual foi concedido a Associaciáo de Liscolas Móreis pelo Mćtodo Joảo de Deus, o terreno que o listado possuia na Avenida Pedro Alrares Cabral, e onde hii-de levintar-se a Escola-Monumento, foi determinido pela Direcẹio (ieral de Instruction Pri-

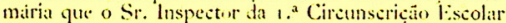
desse a posse do referido terreno at esta Associațio, do que se lavrou o seguinte auto:

Aos seis dias do més de Jullo do ano de mil novecentos e doze, segundo da Republica, compareceram na sede da Inspeceño da P'rimeira Circunscricăo liseolar, os cidadáos António Tavares de Ameida, Elizio Mateus de Campos e José Augtiste de .llelo Vieira, para, na quarlidade de viee-presilente, secretirje e vegal, servindo de

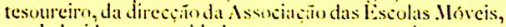
estabelecidia nestit cidade, tomarem posse do terreno que o listado possui na freguesia da lapil, desta cidade, e que ¿ limitado ato norte pela . Vrenda Pedro Alvares (abral, e as sul e naseente por propriedades particulares e a poente por terrenos do Muntcipia de Lisboa, iirea de cinco mil e cem metros quadrados, o qual terreno foi cedido a referida associateito pela lei de quinze de llaio do corrente ano para o fim e nas condiçóes estipuladas na mesma lei. listiundo presente o Sr. Antonio Francisio dos Simtos, inspector dit dita circunscriçio, este funcionario reconhece iomo os próprios os cidadãos acima indicados e nos termos da autorizaç̣óo dada pela Direcçāo Geral da Instruçāo Primiria em sua nota numero novecentos e setentil e um, livro quinto da segunda reparticís de treze de Junho tiltimo, thes deu posse do citado terreno $\mathrm{cm}$ nome do Estado, na presença das testemunhas José P’into Giuedes de Paiva e José Lizaro dos Arcos. Depois do que eu Caetano. José Pinto, secretirio da Inspeç̧̌̆o mandei lavrar o presente auto que, depois de lide, con todos os presentes assino.

Lishoa e Inspecián da 1." Circunscriciáo Escolar da Republica, em 6 de Julho de ro1 $2=$ - António Francisco

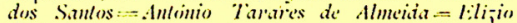

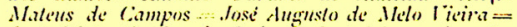
Josi linto (inedes de raira lose Lajaro dos . lr. ios $-=$ Cial ano Jusi P'into.

,

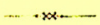

\section{ANO LECTIVO DE 1911-1912}

\section{BALANCOO DO MOVIMENTO DF MISSOES}

Foram em numero de 18 as missóes escolares efectuadas no ano lectivo tindo, mas quais se matricula. ram $1: 138$ alunos, crianças e adultos, - 831 do sexo masculino e 307 do sexo feminino. (O numero de alunos apurados foi de 528 i.fi,t por cento dos matriculados), sendo 355 do sero masculino e $1-3$ do sexo feminino.

No mapa seguinte damos a sumula des resultados obtidos nas míssóes no ano lectivo de $1911-1(1):$, no que di\% respeito atos alunos que eram analfabetos quando se matricularam :

\section{Alumes matriculaclon}

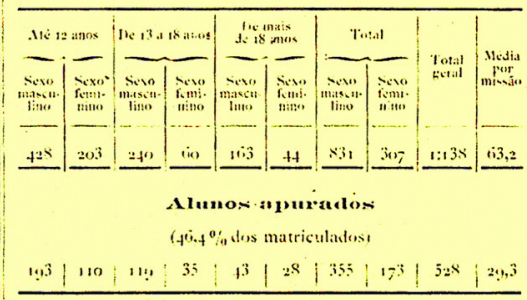

No numero dos alunes apurados figuram somente aqueles que prestaram as respectivas provals finais de aproveitamento, 26 i. dos quais tiveram um periodo complementar de aperfecicoamento que variou de dois a cinco meses, nas dez missies que paral èse fim foram prolongadas.

Fin algumas missóes, alem dos alunos analfabetos a data da matricula, foram leccionados individuos que se inscreveram para se aperfeiçoarem em leitura, escrita e contas, e que tambem no fim dos traballos escolares prestaram as provils do seu apericicoamento.

Na missío n." $2 g^{6}$, por exemple, que funcioneu $\mathrm{cm}$ Víana do Castelo, na Escola Domingos José de Morais, foram inscritos to alunos nestats condicóes: 29 deles deran as prosias de aperfeicoamento; 0 tizeram exame do $1 . "$ grau e 7 do $2 . "$ gralu de instruciúo primiria, sendo aproviados.

Na missio n." 3ı, em Barcelos, tambem a respectiva professora habilitcu un aluno para o exame do t." grau e dois para o do z.", yue foram igualmente aprovados. 


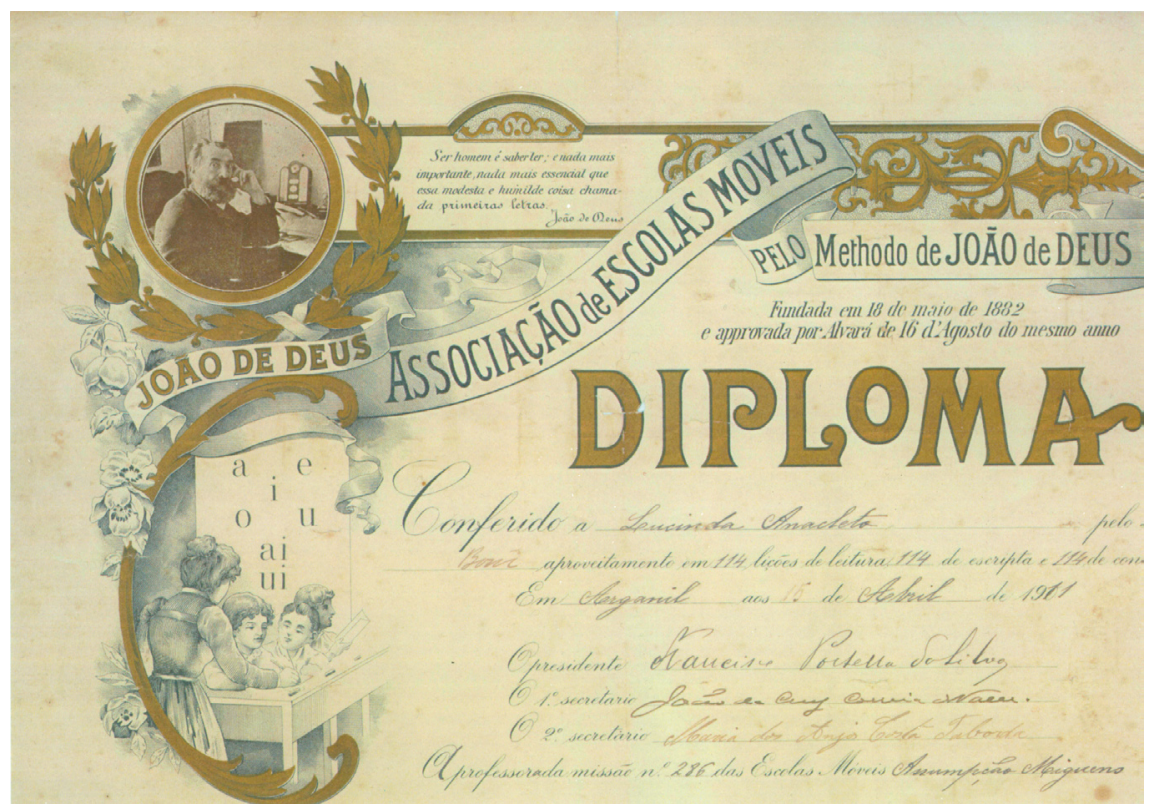




\title{
Jỗo de Deus Ramos, A ACÇÃo e A ESCOLA
}

\author{
Republicano desde os tempos da propaganda ... \\ fazendo ouvir a sua voz em defesa dos direitos da criança \\ e proclamando a necessidade de combater o analfabetismo. \\ Diário Popular nº 3994 (15. 11.1953)
}

João de Deus foi o pensamento, o filho foi a acção; enquanto o primeiro criou o método, o outro, João de Deus Ramos, estruturou a escola que permanecia firme, duradoura e utilíssima (Júlio Dantas apud Jardins-Escolas João de Deus, 1956, p. 24). Depois de perder o pai aos dezassete anos, João de Deus Ramos (1878-1953), o terceiro filho, procura assumir a chefia da família. À semelhança do pai, cursou Direito na Universidade de Coimbra (1897), onde estreitou laços com João de Barros de uma vez para sempre. A sua epistolografia revela outras amizades com individualidades de vários quadrantes: Afonso Costa, Afonso Lopes Vieira, Bernardino Machado, Carolina Michaëlis, Jaime Cortesão, Leonardo Coimbra, Manuel de Laranjeira, Teófilo Braga, entre muitos outros.

Concluído o curso em 1902, é nomeado professor do Liceu Camões. Nesse mesmo ano publica o estudo Os altos princípios do método João de Deus, iniciando no ano seguinte uma série de conferências pedagógicas sobre o método de seu pai, bem como outras relacionadas com o analfabetismo, a legislação escolar e a criança. Entre 1905 e 1910, dirigiu a revista A Instrução do Povo e, em 1907, passa a dirigir o Boletim das Escolas Móveis pelo Método João de Deus. Assume, no ano seguinte, a Direcção da Associação Escolas Móveis pelo Método João de Deus alterando, nesta altura, o nome para Associação de Escolas Móveis pelo Método João de Deus e Bibliotecas Ambulantes e Jardins-Escolas. Em 1911, fundaria o primeiro Jardim-Escola em Coimbra, acontecimento que será descrito oportunamente. Em 1915, casa com Carmen Syder de Deus Ramos, de quem teve quatro filhos e, desta vez, seria a segunda filha, Maria da Luz de Deus Ramos, que haveria de continuar a obra do pai.

A par desta eminente obra pedagógica, João de Deus Ramos destacou-se ainda do ponto de vista político. Republicano e democrata, vai situar-se na ala liderada por Afonso Costa. Foi iniciado na Maçonaria, entrando para a Loja Solidariedade em 1909 (Lisboa, Grande Oriente Lusitano Unido), com o nome simbólico de Antero. Em 1913 passa para a Loja Redenção, regressando em 1922 à Loja onde fora iniciado. Em 1924 atinge o $7^{\circ}$ grau do Rito Francês. Após a implantação da República, João de Deus Ramos foi nomeado chefe da Repartição Pedagógica, mas acabou por se demitir a 17 de Março de 1911 (Rómulo de Carvalho, 1981, p. 664). A partir de 1912 a actividade política torna-se mais visível, altura em que é eleito Governador Civil da Guarda; no ano seguinte, é eleito Deputado por 
Lamego e Governador Civil de Coimbra, e no ano subsequente, eleito Deputado por Alcobaça. É de destacar a sua intervenção na Câmara dos Deputados na sessão de 29 de Agosto de 1915 sobre a Lei Orçamental do Ministério da Instrução Pública de então, criticando o facto de esta proposta não permitir o estabelecimento de escolas móveis onde já existissem escolas fixas, apresentando, para tal, as diferenças dos objectivos de uma e outra escola "as Escolas Móveis têm como finalidade desenvolver a economia, a sociedade e a política, através da alfabetização de adultos e crianças" (C. Varela Chá-Chá, 2009, p. 125).

Depois de ter recusado desenpenhar funções no governo de Sidónio Pais (1917-1918), é nomeado, no dia 21 de Janeiro de 1920, Ministro da Instrução Pública, altura em que cria o Curso de Didáctica Pré-Primária. Na qualidade de ministro desta pasta, procura levar a cabo uma reforma educativa, mas tal não se concretiza conforme veio a esclarecer, mais tarde, no livro O Estado Mestre-Escola (1924): "Era preciso alargar a jurisdição do Ministério. Além dos estabelecimentos de ensino que lhe estão subordinados, deviam pertencer-lhe também os institutos de assistência pública (...) e bem assim os serviços de higiene, os hospitais, as misericórdias, os campos de jogos, escolas de educação física; e também os teatros e os cinemas, etc. (...)". A verdade é que, conforme confessa, desiludido, o filho do poeta: "Nenhuma [reforma educativa], porém, até hoje, obedeceu a um plano de conjunto que tivesse por base essencial o estudo das qualidades próprias, bem definidas, e as condições históricas, bem demarcadas do povo português." (apud C. Varela Chá-Chá, 2009, p. 125). João de Deus Ramos, perspectivando a política numa dimensão missionária, promotora do progresso humano - mais do que um projecto individual -, manifestou o seu sentido social e o zelo pelo superior interesse da criança em várias medidas políticas: “em relação ao povo, para além da preocupação alfabetizadora, regulamentou a emigração, fez obras no manicómio e nos hospitais e uma campanha à indústria vidreira então em crise, para ajudar os operários (...)", procurando ainda afastar a criança de meios pouco adequados ao seu desenvolvimento, como é o caso do campo de refugiados, espaço em que as crianças se encontravam misturadas com os adultos.

Em 1925, é eleito Ministro do Trabalho no governo de José Domingues dos Santos. Abandonará a vida política depois do golpe de 28 de Maio de 1926. 

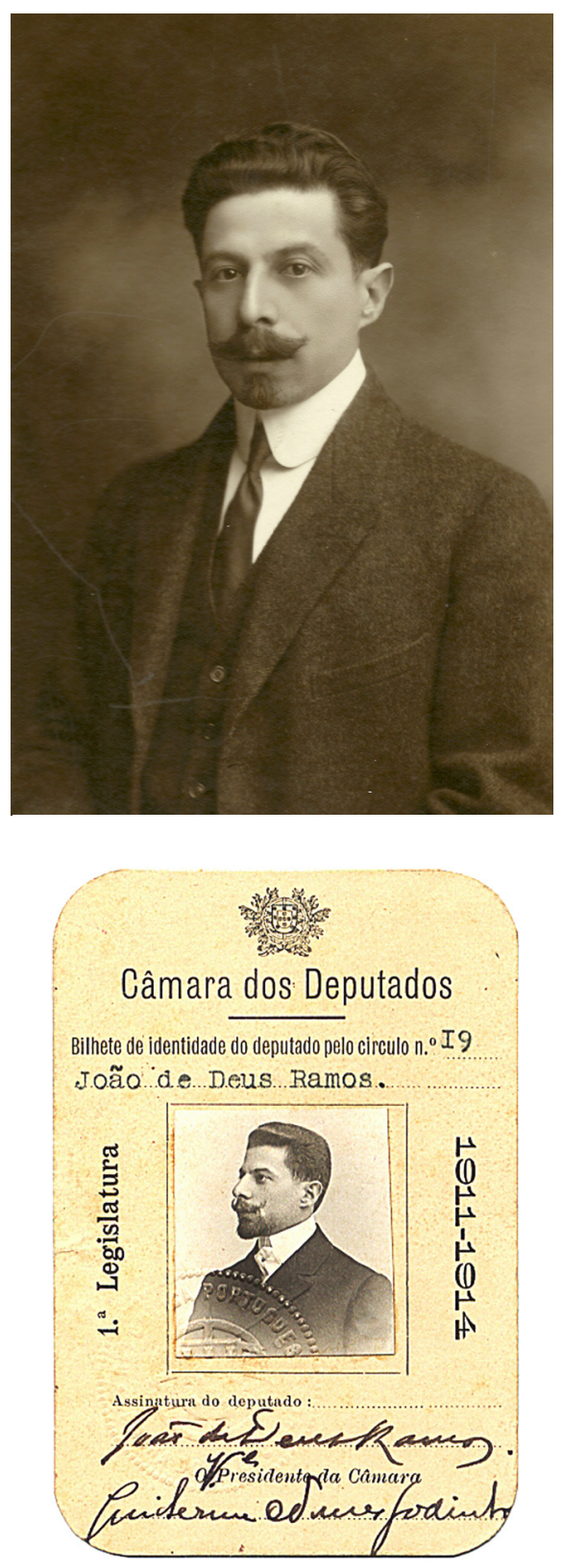

Fig.13: João de Deus Ramos (1878-1953).

Fig.14: Cartão de identificação do deputado de João de Deus Ramos (1911-1914). 
Legou-nos uma produção bibliográfica muito significativa (mais de vinte títulos). Em 1901, publica na Imprensa da Universidade de Coimbra, o Guia da Cartilha Maternal: Prático e Teórico ou Arte de Leitura, o primeiro impulso para dar continuidade à obra de seu pai e já no ano seguinte publica, no mesmo sítio, o já referido estudo Os altos princípios do método João de Deus, no qual João de Deus reafirma e abraça aquele que será o seu projecto de vida e o fundamento de uma duradoura obra pedagógica. Um mês antes da morte de seu pai, João de Deus Ramos crtica a exclusão da Cartilha Maternal do ensino oficial, investindo-se agora da responsabilidade de fazer valer o sonho paterno: "As suas grandes obras é que não morreram; não podem morrer...porque são a verdade e como Ele dizia, ainda que se possa abafar, não se extingue!” (J. de Deus Ramos, 1902, pp. VIIIXIII).

Dedicada ao ensino primário, encontramos uma vasta produção no domínio legislativo. Em 1905, na qualidade de director da revista Instrução do Povo publica "O Grande Marquês de Pombal - a favor do monumento" e "Proposta de Lei” (1905) e no ano seguinte, "Um projecto de Lei - As Escolas Móveis subsidiadas pelo Estado”, pouco depois de assumir a direcção da Associação de Escolas Móveis. Em 1911, em conjunto com João de Barros, publica A Reforma da Instrução Primária, o primeiro enquanto chefe da Repartição Pedagógica convidado por António José de Almeida (ministro do Interior) - e o segundo, o poeta João de Barros, na qualidade de Director Geral da Instrução Primária. Este projecto foi, com efeito, elaborado por uma equipa de reconhecida qualidade, pois além dos dois pedagogos já referidos, era composta por mais três ex-directores das escolas normais de Lisboa, Porto e Coimbra. Contudo, depois de ter sido entregue ao Ministro do Interior, António José de Almeida, o texto original da reforma da instrução primária foi adulterado, originando o decreto de 29 de Março de 1911. Este facto conduziu ao abandono de João de Barros e de João de Deus Ramos dos respectivos cargos, que vêm depois explicar publicamente o sucedido no referido texto. Quatro anos mais tarde, redigiu A Reforma do Ensino Normal - O projecto de lei. Discursos e pareceres na Câmara dos Deputados. A produção bibliográfica sobre o problema legislativo do ensino primário é vasta, pois para João de Deus Ramos, “o progresso do país depende dos programas escolares, da organização escolar, da preparação dos professores, dos métodos e sistemas de ensino. (...) Tudo depende directamente do Estado." (vide C. Varela Chá-Chá, p. 129).

Produziu ainda obra de reflexão política, o já referido $O$ Estado Mestre-Escola e a Necessidade das Escolas Primárias e Superiores (1924); de teor sociológico, como $A$ Criança em Portugal antes da Escola Primária (1940), texto apresentado no Porto a convite da Liga Portuguesa da Profilaxia Social e, no mesmo ano, O Analfabetismo nas Beiras, comunicação apresentada no ano anterior no VII Congresso Beirão. 
É ainda de destacar textos para uso escolar, Fábulas para Gente Moça [1955], O Livro da Capa Verde para gente moça (1948) juntamente com Jaime Lopes Dias.

O obreiro do sonho do poeta João de Deus verá erguerem-se, até ao fim da sua vida, onze Jardins-Escolas: Coimbra (1911), Figueira da Foz e Alcobaça (1914), Lisboa (1917), Alhadas (1927), Leiria e Castelo Branco (1936), Viseu (1943), Mortágua e Chaves (1948), Porto (1951). Em 1917, inaugura o Museu João de Deus - Bibliográfico, Pedagógico e Artístico. Em 1928, João de Deus Ramos juntamente com João Soares, Virginio Vicente da Silva e Mário Pamplona Ramos, funda o Bairro Escolar do Estoril, uma nova organização colegial para a educação da juventude (C. Varela, 2009, p.134). Em 1943, João de Deus Ramos funda a primeira Escola de Educadoras de Infância com o nome de Curso de Didáctica Pré-Primária pelo Método João de Deus.

Deste legado, destacamos a criação do Museu João de Deus - Bibliográfico, Pedagógico e Artístico (1917) que tinha dois objectivos fundamentais: ser um monumento ao poeta-educador e uma biblioteca de apoio à cultura portuguesa. Mais uma vez, contou com a ajuda de Afonso Lopes Vieira, que levou à imprensa este projecto, com o plano arquitectónico de Raul Lino, com pinturas decorativas de Leal da Câmara. Conforme nos dá conta o Diário de Notícias (12 de Janeiro de 1917): "É bem um momento para se prestar culto à memória daquele que, como ninguém, soube cantar as crianças, as flores e os desgraçados. Tem simplicidade, graça e espiritualidade.” Nesta Praça da Concórdia, conversaram figuras como Afonso Lopes Vieira, João de Barros, Joaquim Manso, Aquilino Ribeiro, Carlos Olavo, Hernâni Cidade, Vieira de Almeida, David Mourão-Ferreira. Actualmente recebe importantes sessões literárias, conferências e concertos musicais.

Falecerá no dia 15 de Novembro de 1953, na sala do Museu João de Deus com 75 anos, depois de ter dedicado mais de meio século à educação infantil e juvenil, convicto de que este era o único caminho para o progresso da sociedade, da política, da cultura e da economia. 
Ghamou-ce for-o ders Parnos

exactamente o vomepatern.

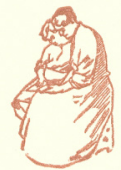

LISBOA - 1972
ÊLÉMENTS POUR L'HISTOIRE

D’UNE ÉCOLE DE FORMATION DES

INSTITUTEURS DE MATERNELLE

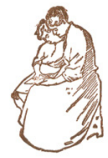

LISBOA

1991

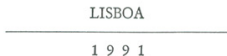

Manuela de Azevedo

João
de Deus

Ramos

Vida

e obra

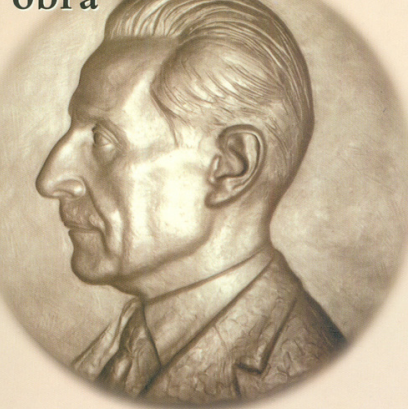

Associação de Jardins Escolas João de Deus

noticias

Fig. 15: Ferreira de Castro, Chamou-se João de Deus Ramos exactamente o nome paterno, Lisboa, 1972. Fig.16: A. Ponces de Carvalho, Éléments pour l'histoire d'une école de formation des Instituteurs de Maternelle, Lisboa, 1991.

Fig. 17: M. de Azevedo, João de Deus Ramos. Vida e obra, Lisboa, 1997. 


\section{Os caminhos de um Sonho: o $\mathbf{1}^{\circ}$ Jardim Escola João de Deus}

Em 1907, pouco antes de João de Deus Ramos assumir a direcção da Associação das Escolas Móveis, reconhecia já que o carácter temporário das missões pedagógicas não permitia uma aplicação eficaz do método João de Deus. Assim, nesta altura, foram também reformulados estatutos da Associação e a mesma necessidade objectivada: "Instituir Jardins-Escolas para crianças de três a sete anos, onde seja aplicado, em toda a sua plenitude, o espírito e doutrina da obra educativa de João de Deus, modelando assim um tipo português de escola infantil." (Associação de Escolas Móveis pelo Método de João de Deus, Bibliotecas ambulantes e Jardins-Escolas, 1908.

Em 1908, empreende uma viagem pela Europa, sobretudo à França e à Suíça, tendo como objectivo conhecer o funcionamento dos Jardins de Infância desses países. Dessas visitas resultaram contactos fundamentais com diferentes métodos de ensino e pedagogos, entre os quais Friedrich Wilhelm August Froëbel (1782-1852), Ovide Decroly (1871-1932) e Maria Montessori (1870-1951). Recolhidos estes contributos estrangeiros, a ideia do Jardim-Escola nacional começou a ganhar forma, mas teria de ser adaptada à realidade portuguesa:

Os Jardins-escola prestar-se-ão esplendidamente para habilitar melhor os nossos professores e facilitarão, como centros de propaganda, o desenvolvimento das bibliotecas populares, bem como a realização das palestras e leituras públicas com o auxílio de projecções luminosas. (...) Desta sorte a Associação, além de contribuir esforçadamente para a extinção do analfabetismo, terá lançado as bases fundamentais de uma urgente reforma no processo de todo o ensino, começando como deve ser, pelo ensino de infância, o que se tornará motivo de legítimo orgulho para a nossa Associação e para o País.

(Relatório de Actividades da Associação das Escolas Móveis, 1908)

Não o desanimou a falta de apoio do Estado. João de Deus Ramos conseguiu reunir fundos para construir o primeiro Jardim-Escola com a colaboração de várias entidades, conforme recorda J. Martins Manso (jornal Defeza, 3 de Fevereiro de 1911): "O plano sorri a toda a gente e toda a gente se mostra pronta a secundá-lo. A Câmara de Coimbra cede o terreno, no Largo do Seminário. Raul Lino encarrega-se da planta. Este promete madeiras e aquele tijolos. (...) De 
novo, a providência se mostra propícia e benigna. Os deuses protegiam amoráveis tão bela iniciativa. As dificuldades amaciavam-se no mais fino veludo."

Com efeito, contou, desde logo, com a cedência do terreno (4800 metros e 70 decímetros quadrados) em 1909 por parte do Presidente da Câmara, o Professor Marnoco e Sousa, e com o apoio de arquitecto Raul Lino, que lhe desenhou uma fisionomia arquitectónica própria de dimensão nacional e cariz funcional, pois afirmava o filho do poeta: "As paredes mestras também são mestras". Destaca-se o facto de serem edifícios semelhantes à arquitectura da casa portuguesa, de modo a que a criança se sentisse o mais confortável possível, além de se ter baseado no modelo Casa dei Bambini de Maria Monterassi (H. Coelho, 2010, p. 17).

Conforme descreve Maria da Luz de Deus Ramos (1962, p.7): “onde as crianças quando entrassem encontrariam um desdobramento do próprio lar. Luz sabiamente doseada (...), decoração sóbria e bom gosto, prevendo que numa escola se tem como elemento importante, desde logo, a possibilidade de subjectivação interior." A título de exemplo, é reservado um espaço largo às crianças de 4 anos, onde decorreriam as suas actividades apoiadas em jogos e movimento, "pois nesta faixa etária não se deve falar em aulas. (...) As crianças dos 4 anos gostam de viver em grupos grandes e em espaços largos e abertos e isto já foi reconhecido por Wallon.” (ibidem). O célebre arquitecto haveria de se tornar seu colaborador ao longo da vida, assim como o artista Leal da Câmara, militante republicano, que pintou os frisos das diversas salas dos Jardins-Escolas. 

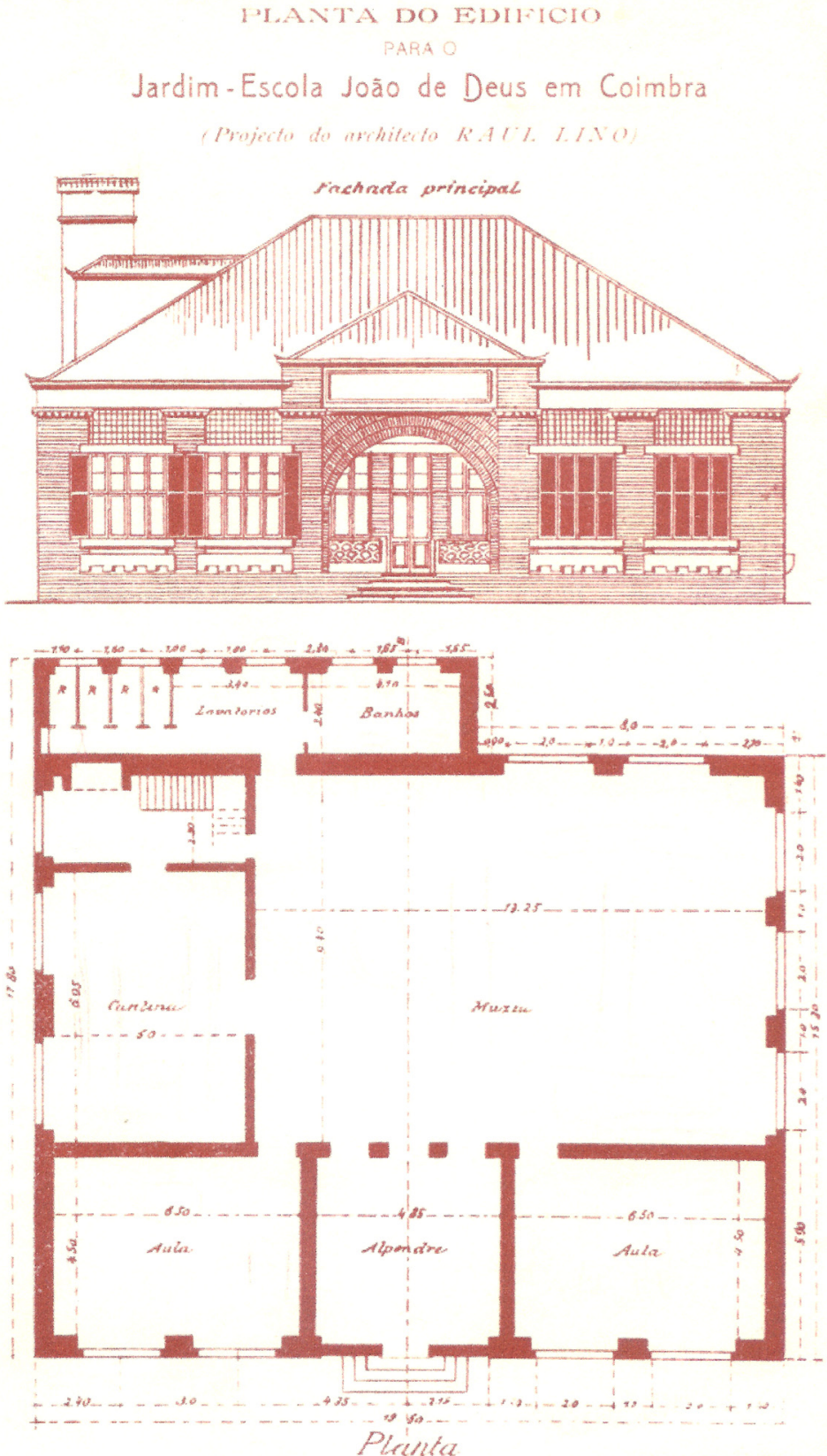

Fig. 18: Projecto para o $1^{\circ}$ Jardim-Escola João de Deus, da autoria do arquitecto Raul Lino. 

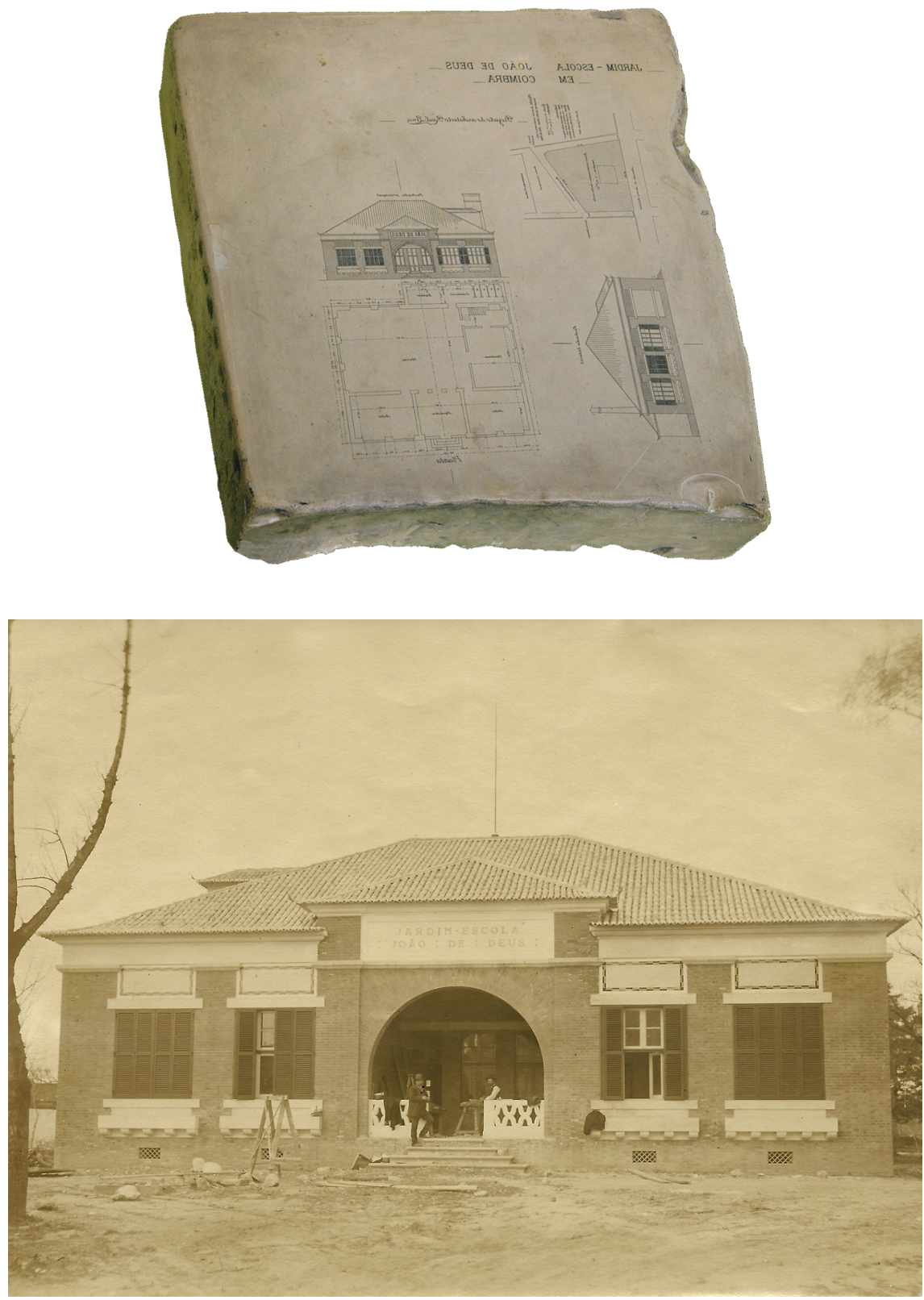


\section{ORFEÃo ACADÉMICO}

Várias entidades colaborariam na angariação de fundos para a construção do primeiro Jardim-Escola. O Orfeão Académico de Coimbra, por exemplo, realizou vários saraus pelo país, sob a iniciativa de António Joyce.

Entre 1 de Abril de 1909 e 27 de Março de 1912, o Orfeão Académico organizou aproximadamente cerca de seis saraus: o primeiro conhecido data de 1 de Abril de 1909 e teve lugar no Coliseu dos Recreios. Neste evento discursou o deputado Egas Moniz que enaltece o projecto do Jardim-Escola e evoca João de Deus, colocando-o ao lado de pedagogos de renome europeu: Rousseau, Comenius, Pestalozzi e Froëbel.

O segundo sarau teve lugar no final do mesmo mês, a 24, no Teatro Príncipe Real, e outros se seguiram até 1912, tendo apresentado em vários espaços, como o Teatro Nacional de S. Carlos, que decorreu no dia 27 de Julho de 1910 ou o Teatro Lethes (Faro), no dia 26 de Março de 1912, e no dia seguinte no Teatro Circo em Braga. Do conjunto dos saraus realizados, destacamos o que decorreu no dia 23 de Março de 1912 no Coliseu dos Recreios tendo sido honrado com um discurso de Bernardino Machado. Além de saraus, organizaram também concertos e, a título de exemplo, referimos o realizado no Teatro de S. Carlos no dia 25 de Março de 1911. A digressão do Orfeão Académico ultrapassou as fronteiras nacionais quando, em 1911, foi convidado pela Association Générale des Étudiants de Paris et Le Comité Franco-Portugais para um conjunto de festas na capital francesa que decorreria pouco depois da inauguração do primeiro Jardim-Escola em Coimbra, no período de 7 a 16 de Abril de 1911.

O Programme des Fêtes deste conjunto de eventos, ilustrado por Leal da Câmara, era também vendido para beneficiar o Jardim-Escola, conforme consta na nota inicial: "Ce Programme Souvenir est vendu au profit de l'entretien du Jardin-École João de Deus de Coimbre, fondé par les Étudiants des Universitaires Portugaises”. É de destacar os elementos da comitiva que acompanhou o grupo coimbrão a Paris: Afonso Lopes Vieira e João de Barros, amigos íntimos de João de Deus Ramos e ligados ao primeiro JardimEscola português, além de Viana da Mota, célebre compositor wagneriano, ex-discípulo de Lizt. O repertório do Orfeão Académico apresentava peças de Mozart, Litz, Bach, Meyerbeer, Berlioz, João Arroio, Pinto Ribeiro, dando especial ênfase ao compositor R. Wagner, como sucedeu no sarau que teve lugar no Teatro Príncipe Real no dia 29 de Abril de 1909, que terminou com a Grande Sinfonia Astral e Wagneriana.

As receitas obtidas pelo Orfeão foram de tal ordem que financiaram quase metade da obra do Jardim-Escola, cerca de $1480 \$ 000$ réis de um total de $4500 \$ 000$ réis. 


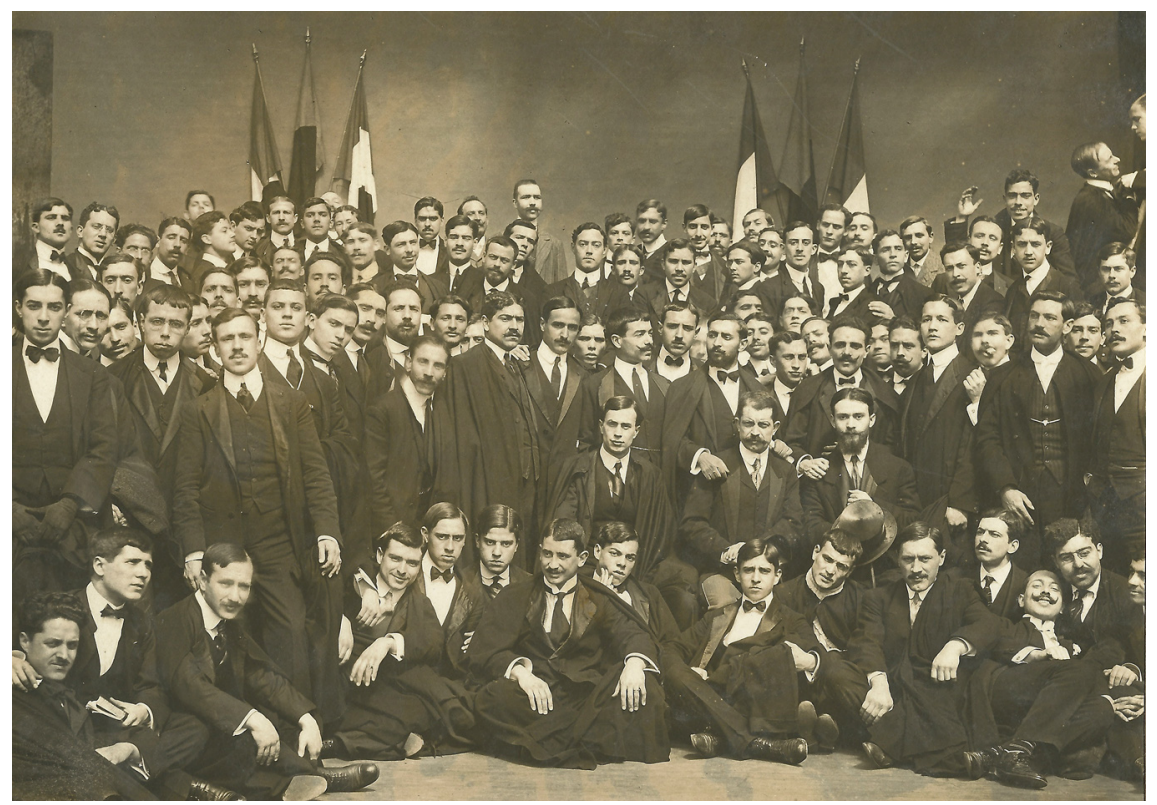




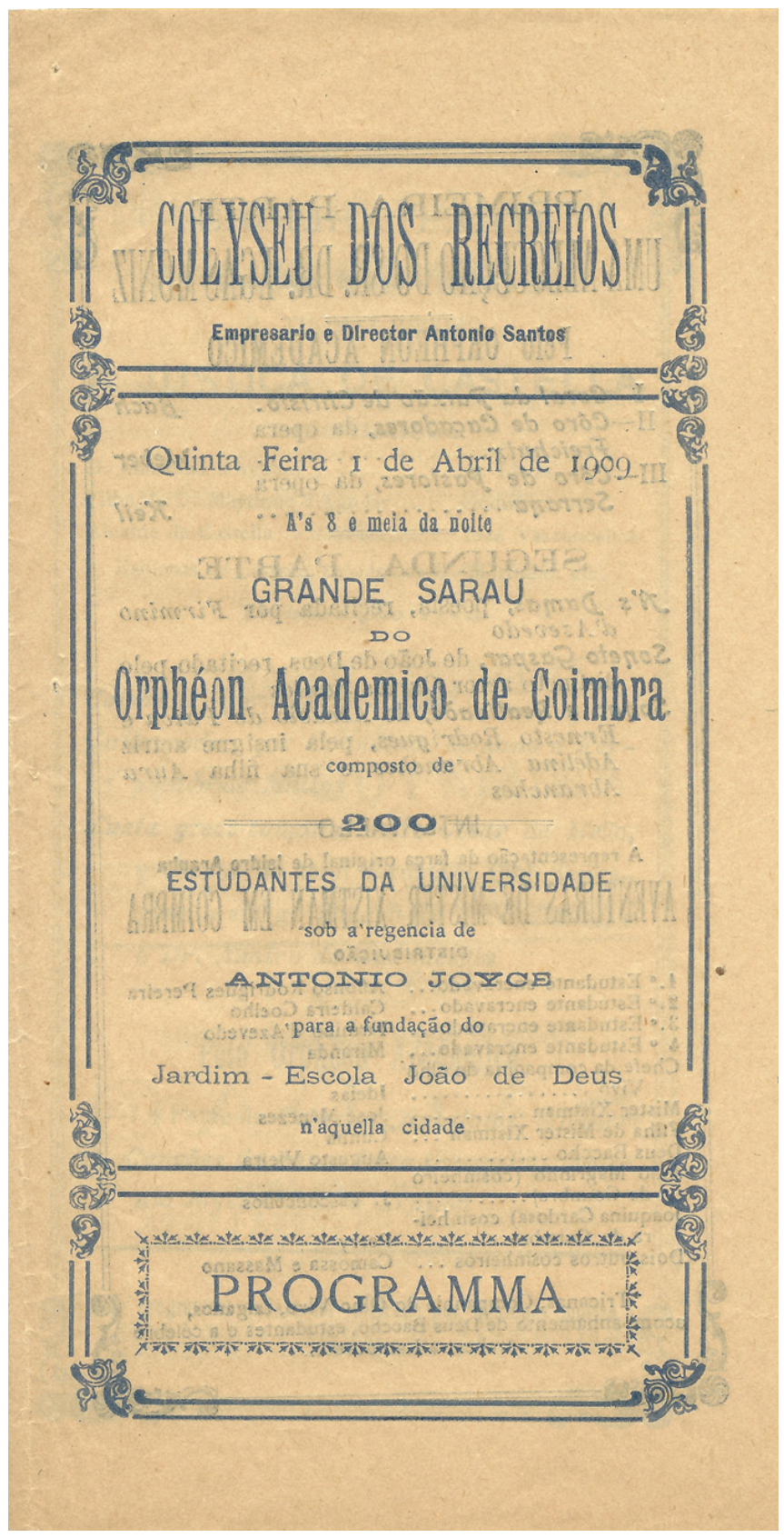

Fig.22: Programa do sarau organizado no Coliseu dos Recreios, no dia 1 de Abril de 1909. 


\section{Sarall do Orfeon Academico de Coimbra no ColiserI dos Recreios em I d'alril de 1909}

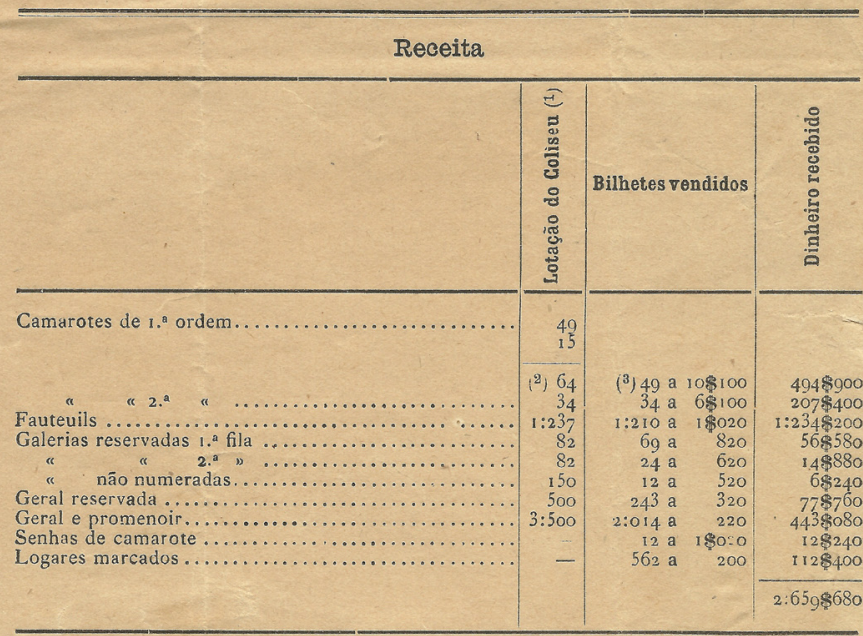

Despeza

Coliseu - Pago ao emprezario Commendador Santos:

Aluguer do teatro.................................. 5008000

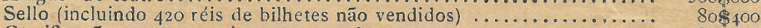
Gratificaçốes aos respectivos empregados....................... $30 \$ 000$

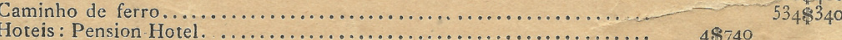

.

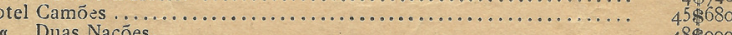

" Duas Naçóes.................................. $48 \$ 000$

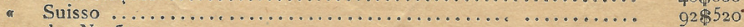

" das Naçôes ..................................................... $92 \$ 000$

Diversas: Nota de caminho de ferro e hotel apresentada pelo ex. ${ }^{\text {mo }}$ secre-

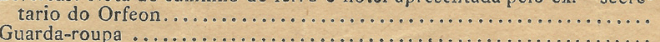

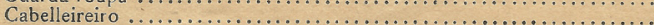

Registo de cartas para remessa de bi betes......................

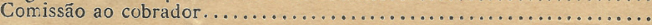

$42 \$ 630$

$2 \$ 400$

$5 \$ 000$

$3 \$ 600$

$10 \$ 000$

$63 \$ 630$

$1: 443 \$ 310$

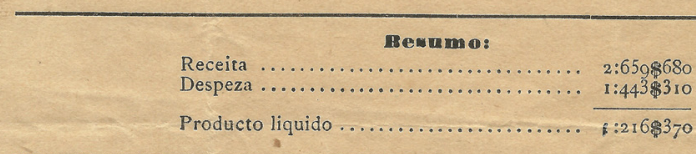

(1) Segundo nota fornecida pelo emprezario.

$\left({ }^{2}\right)$ Jos camarotes de 1 a $^{\mathrm{a}}$ ordem são 49 vendaveis e 15 captivos, que são os seguintes: $\mathrm{A}$, $\mathrm{B}_{1}, 2,3,4,6,10,28,29,30,32,34,38,60$ e 62 . Do camarote $n 0^{\circ} 2$ recebeu-se a importancia, offerecida nelo sr. Commendador Santos.

$\left.{ }^{3}\right)$ O bilhete do camarote $n .^{\circ} 13$, enviado ao sr. Marquez de Franco, foi devolvido depois do sarau. 


\section{A inauguração do primeiro Jardim-Escola João de Deus}

É no contexto da recém implantada República e no mesmo ano em que João de Deus Ramos publica, em conjunto com João de Barros, A Reforma de Instrução Primária, que é inaugurado, em Coimbra, o primeiro Jardim-Escola João de Deus, no dia 2 de Abril de 1911. Trata-se de um modelo de escola de índole nacional numa altura em que as nações "superiormente cultas" avançavam com propostas de institutos escolares de ensino infantil, conforme reconhece o próprio fundador: "Datam os Jardins-Escolas João de Deus da mesma época em que aparecem Decroly na Bélgica com uma escola em Ixelles e a 'Casa dei Bambini' de Maria Montessori na Itália” (Maria da Luz de Deus Ramos, 1997, p. 41).

Durante a Primeira República nasceriam em Portugal mais três Jardins-Escolas: Figueira da Foz, Alcobaça (1914) e Lisboa (1915).

Milhares de pessoas de todas as categorias sociais enchiam o largo em frente do Jardim-Escola e foi tocada "A Portuguesa" pela banda militar da Infantaria 23, acompanhada pelas crianças das Escolas Primárias de Coimbra, que cantaram o hino.

No fim, a assistência fez uma chamada ao arquitecto autor do projecto, Raul Lino que, aparecendo, também foi alvo de uma manifestação.

Foi uma festa lindíssima, carinhosa e comovedora, apesar da chuva incerta da Primavera, que tudo alagava, mas que não conseguia emudecer a voz fremente, a voz alegre, da seiva nova, como não afastou daquela cerimónia, onde o elemento oficial estava largamente representado, a curiosidade simpática da multidão. Houve discursos, recitaram-se versos, e as mais latas personalidades de Coimbra, e os melhores representantes das últimas gerações, vieram ali prestar, João de Deus Ramos e à sua obra, a homenagem da sua admiração e do seu respeito.

(...) O que sobretudo me impressionou n'esse dia, foi o acolhimento de entusiasmo que o Jardim-Escola teve por parte do povo, do povo para quem ele se construiu, do povo que sabe, ou sente, que a ideia fundamental que presidira à fundação daquela casa fora simplesmente esta: dar às classes populares, as únicas ainda sadias e fortes no país, educando-lhes os filhos, mais uma possibilidade de ressurgimento e de progresso.

João de Barros (1911, p.46) 


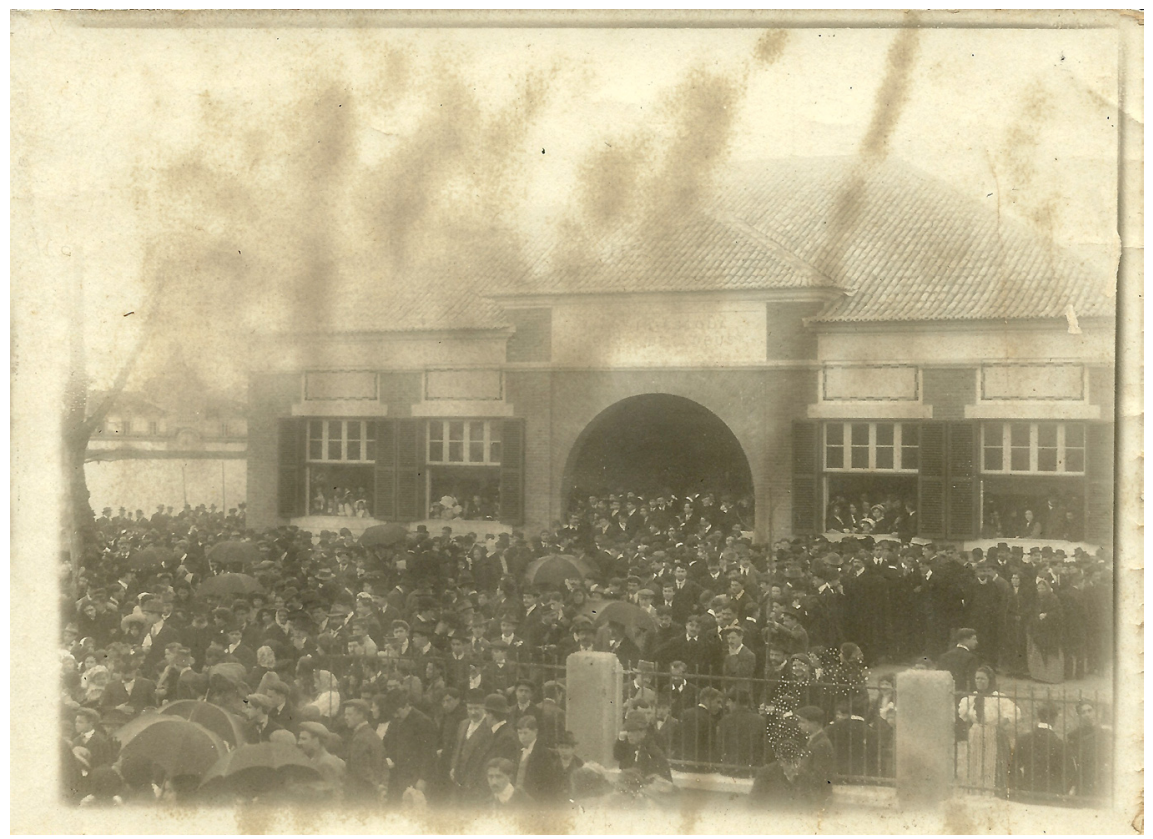




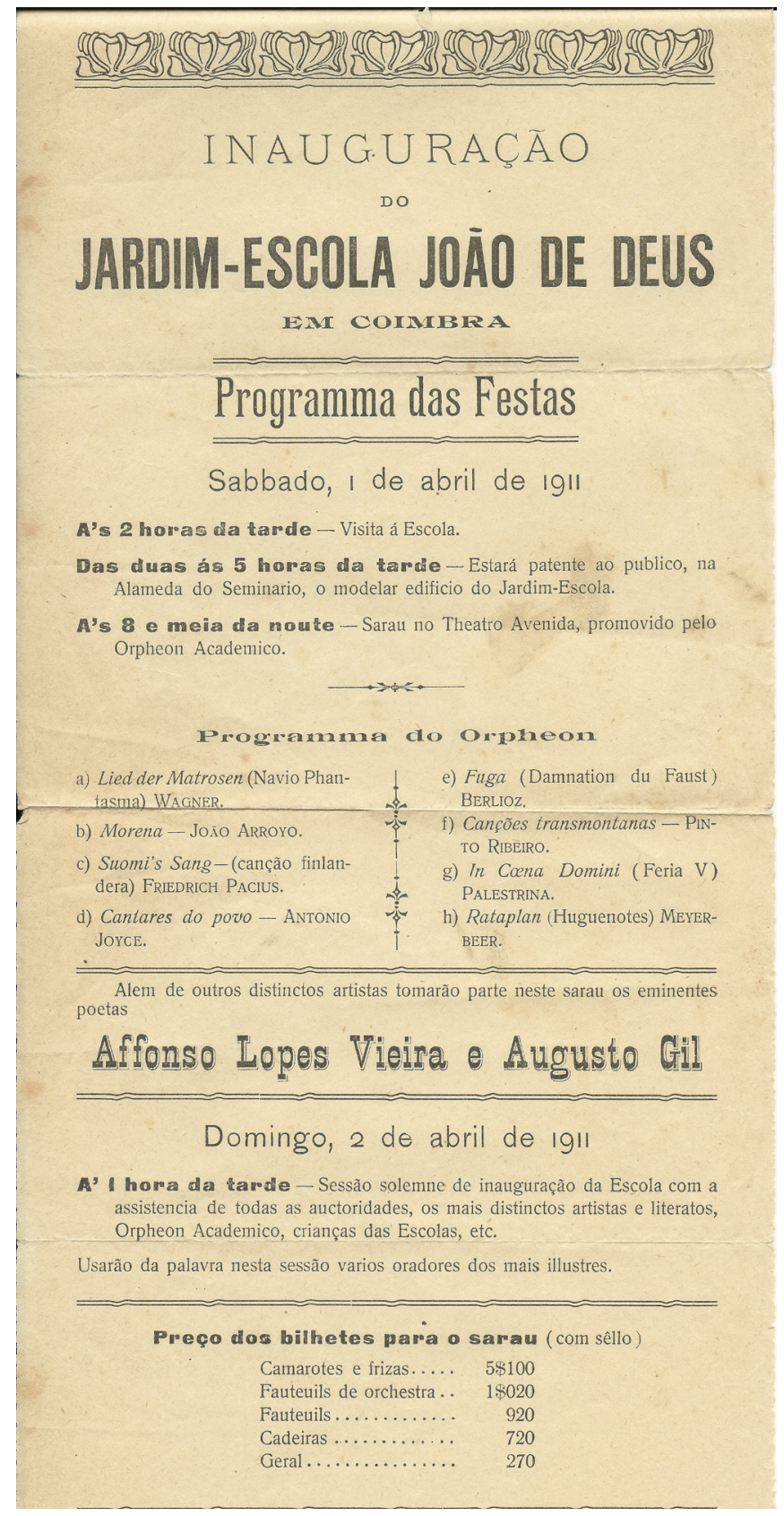

Fig.25: Panfleto relativo à inauguração do $1^{\circ}$ Jardim-Escola João de Deus de Coimbra. 


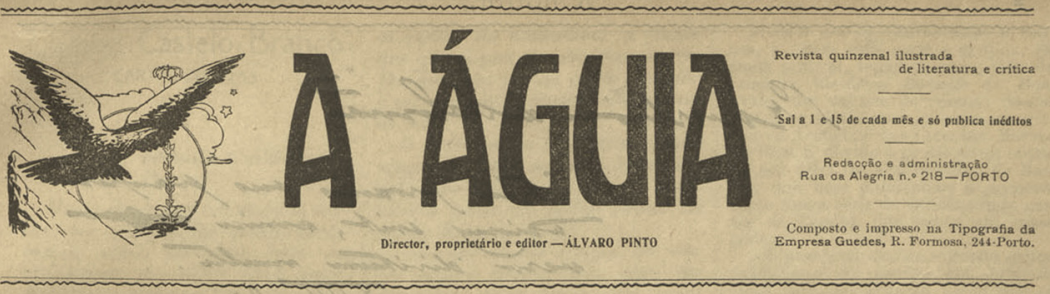

\section{Jardim-Escola JOAO DE DEUS}

(CRONICA DE COIMBRA)

A oito de março, inaugura-se, no Largo do Seminario, um desses graciosos e candidos institutos de ensino que 0 genio amoravel da pedagogia moderna criou num gesto de infinita ternura pelas creancinhas de trez a sete annos - auroras de amor rompendo para o mundo, vivos enigmas que $s o ́$ as profeticas intuiçð̃es das mães e dos mestres são capazes de decifrar. Será uma festa de arte e bondade creadora que reunirá certamente, no mesmo proposito de simpathia, homens cujo o espirito educado e fertil em iniciativas magnanimas traduzirá, na linguagem forte e arrebatadora dos convictos, toda a grande esperança que actualmente move os constructores da democracia.

Ninguem pronunciará palavras inuteis, verborrêa putrida de cabeças estoiradas para os effeitos do pensamento cheio de fogo e novidade: o que se disser, estou convencido disso, inspirar-se-ha na indefectivel sinceridade dos que se propõem resgatar o nosso povo pela educação $e$ instruçç̃o.

Para longe todo o estrepito incomodo de fanfarras retoricas, palavreado esteril de declamadores que estão para a intelligencia como a hipocrisia para a religiăo!

Eloquencia simples, mas persuasiva, è que se quer, Esta não faltará, com certeza. Annuncia-se já a vinda a Coimbra de um grupo de poetas, prosadores e artistas-claras chammas da profunda espiritualidade portuguêsa. E estes não se conservarão calados, porque alguns delles, pelo menos, erguer-se-hăo para celebrar o alvor de renascimento que se accusa nitidamente na linha do horisonte.

Teixeira Gomes, a maravilhoso mestre que, depois de Eça, tem renovado a syntaxe ritmica da nossa prosa, elle

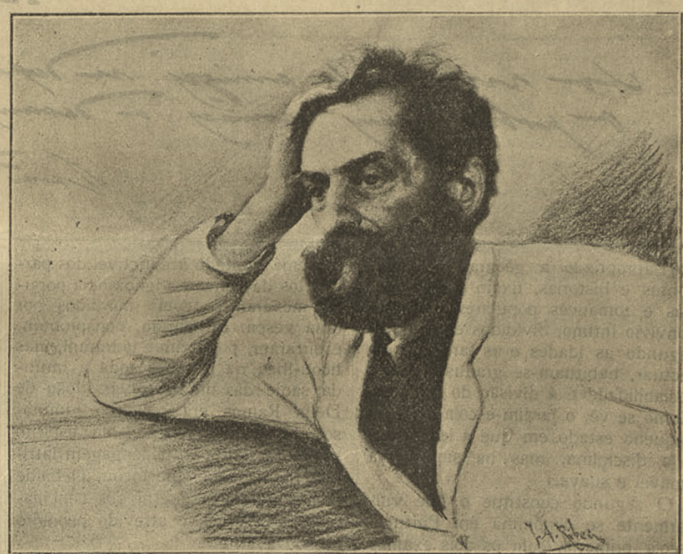

JOAO DE DEUS

(Devenho de Jožo Augueto Ribeiro.)

que, por ter perdido a moral... vulgar, se entregou ao labor hellenico de captar em imagens de oiro a sensação em todo o seu ondulante probeismo, dirá uma conferencia, consagrada á psicologia infantil. Escusado é insistir sobre o grande mimo litterario que deve ser um tal trabalho.

João de Barros, alto funccionario da republica, maior altura de poeta ainda que de funccionario - $a$ inspiraşão riquissima na livre apprehensão dos largos ritmos da vida e da natureza - na graça revolta da sua oratoria, proferirá algumas daquellas verdades que the saem da bocca, com o feitio semi-ironico que the é proprio.

E tambem Lopes. Vieira, o delicadissimo impressionista das Cancões do Vento e do Sol, que hoje fundiu no seu lirismo a aspiraça e a emoção, o terno paganismo dos sentidos e a piedade comovida, segundo a sua maneira discreta, quasi confidencial, comunicar-nos-ha qualquer das enternecidas visões nascidas do seu culto pelos pequeninos. E como estes, outros tomarăo a palavra, sem duvida.

O Jardim-Escola João de Deus é - unico estabelecimento no seu genero, entre nós. A instrucção primaria, em terras, onde a cultura do espirito se realisa efficazmente, abrange trez graus: infantil, média e superior.

O primeiro é consagrado ás creancas de trez a sete annos e visa principalmente educar-lhes os sentidos. No ultimo anno de frequencia, iniciam-se nos misterios da leitura, escripta e numeracão. Antes deste final aprendisado, cuidam só de brincar, fixando conjunctamente tenuissimas liçros de coisas. Entregam-se a exercicios simplicissimos de gymnastica, tomam o seu banho diario, trabalham, segundo a sua fantasia, em modelagem, cartão e cubos, ouvem musica, esbocam rudimentares compassos da dansa, praticam agricultura em jardinetes e hortejos, estudam em mate- 


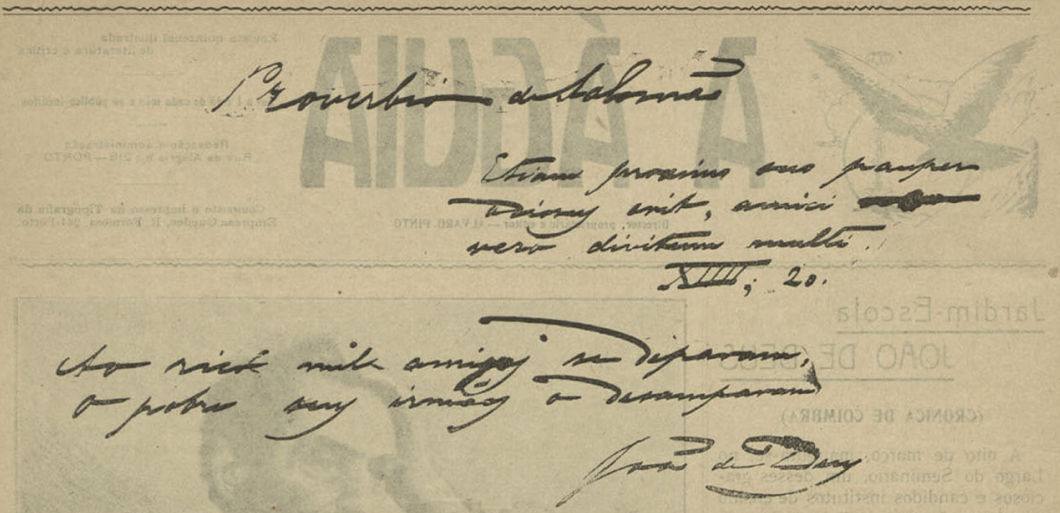

rial apropriado a geografia, ouvem contos e historias, fixam curtas poesias e romances populares, etc. No convivio intimo, divididos em classes, segundo as idad'es $e$ as tarefas a effectuar, habituam-se gradualmente á sociabilidade e á divisão do trabalho. Como se vê, o jardim-escola é já um pequeno estado em que a lei impera e a disciplina, mas na sua fórma amavel e suave.

O segundo constitue a que vulgarmente se denomina em Portugal escola primaria, com os dois exames de primeiro e segundo grau.

O terceiro, que se destina a rapazes de doze a quinze annos, suppõe já a razáo formada e em pleno desenvolvimento. Tem um valor quasi paraleilo á primeira secção do curso dos lyceus, manifestando, porém, um caracter menos theorico, porque tende funccionalmente a preparar homens que hão de tirar todo o proveito do ensino recebido na propría regiăo em que a escola estiver situada.

Ora destes tres graus de cultura, quer saber o leitor quantos a risive competencia da nossa desorada pedagogia official veio a crear? Unicamente o medio! E este, Deus sabe em que avaras e mesquinhas proporçres!...

Joāo de Deus Ramos, dentro do ambito do seu apostolado de propagandista, resolveu começar entre nós a fecundissima obra das escolas maternaes ou jardins-escolas, attenta a brutesca inintelligencia dos nossos mandantes. Appellou para a iniciativa privada, que acolheu a sua palavra iniciadora com carinhoso enthusiasmo. Ainda assim, que enorme serie de difficuldades!
A má vontade irreductivel dos partidarios da venenosa ignorancia popular mexeram-se como mordidos por uma vespa. Intrigaram, conspiraram. espirraram, polluiram e ladraram, mas ficou-lhes na dentuça toda a imunda sanie das almas torvas. João de Deus Ramos era o verbo luminoso, a logica invencivel do espirito novo, portanto, a podengagem latridora nem sequer the tocou. Debalde lhe moveram a guerra dos conciliabulos e alfurjas, 0 atrevido peoneiro passou ávante.

Queria completar o pensamento generoso de seu pae, ao escrever a Cartilha Maternal a qual, como do seu titulo se deduz, era offertada as mães portuguésas para que estas ensinassem, com a incomparavel affectividade do seu magisterio, os filhinhos, apenas o intellecto nellas começasse a sorrir com as suas promessas matinaes.

Mas achar-se-hiam todas em condiç̃es de corresponder aos desejos e ao convite do autor do Campo de Flores?

$\mathrm{N}$ ao, incontestavelmente.

As mulheres do povo, na sua enorme maioria, eram improprias para täo encantadora missão. Qual o melhor processo para supprir semelhante lacuna?

Estabelecer escolas para a infancia mais tenra e mais desprotegida dentro do nosso lastimavel regimen de ensino. Eis o intuito soberano que avigorava João de Deus Ramos nas suas predicas incansaveis, o que the dava energia para romper contra os malevolos que tentavam reduzi-lo á inação.

- ${ }_{N}$ ao sei para que elle anda com tanta massada!....-disse-me uma noite, junto á mesa de um café lisboêta, um poderoso ruminante, desabusado na sua lucrativa preguiça de burocrata, estipendiado copiosamente pela prodigalidade de governos ignaros, premiadores de mediocridades intriguistas. Não sabia nem podia saber, o espesso estupidarrão.

Como é que os arranjistas se revelariam capazes de comprehender, por exemplo, a dealbante dedicação de Antonio Joyce e do Orfeon academico que se votaram de alma e coraçāo a colher recursos para levantar do sonho até á realidade de agora 0 jardim-escola?

E todavia esse bando de rapazes apaixonados pela ideia tentadora divulgada por João de Deus Ramos, correram as principaes cidades de Portugal, dando espectaculos que ao mesmo tempo alvorocaram a dormente sensibilidade das turbas e attrahiam numerario para o edificio a construir!

Bellissima cruzada, a dos orfeonistas!

E como celebrar dignamente a collaboração de Raul Lino, 0 architecto do jardim-escola, de Antonio Carneiro e Christiano de Carvalho que se promptificaram a cuidar da decoraça âo artistica de duas salas? Que no dia da inauguração elles compareçam para acclamarmos e saudarmos o esplendido gesto de amor que tiveram por uma aspiração que hoje é um facto e que ámanhã se multiplicará como os pães de que falla a Escriptura...

Coimbra, 1911

$$
\text { Gagan: Hartai Mann }
$$




\section{ENSINO PRIMARIO ข: 380}

sapuenca

MINISTERIO

EDUCACAO NACIONAL.

INSPECCALO GERAL.

ENSINO PARTIOULAR

4

\section{ALVARA}

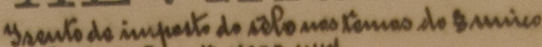
do antigo of do Oherets $N: 23.447$

Aicndendo ao que me representou a CXssociacião de Yardius Escolas yoão de Orus

pedindo autorizdyâo para abrir um estabelecimento de ensino primărio particular

Coimbra trogusia de Si Dlowa concello de Coimbra distrito de Coimbra

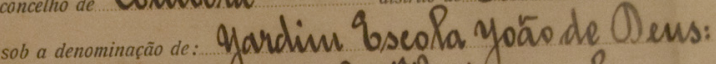

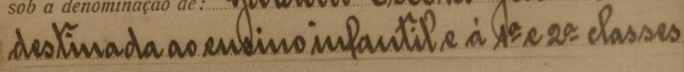
matéria :

Hei por bem conceder a respectiva autorizaçâo nos termos seguintes:

O estabelecimento, cujo funcionamento é autorizado, pode receber 90 alunos

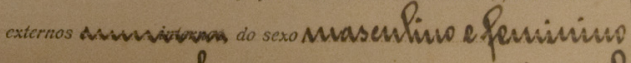
Em regime de plamos a prognamas propriose oficiais É seu actual director groão de Qfens Ramis Está situado na Chorida Yulio of enyiques Ministério da Educaçâo Nacional em 17 defenuiro de 1958 


\section{Jardim-Escola JoÃo de Deus, um tipo INTEIRAMENTE PORTUGUÊS}

Educar na mais ampla expressão da palavra. Educar os sentidos, portas de comunicação com o mundo exterior, educar a vontade, favorecendo o auto-dominio, educar a memória.

Maria da Luz de Deus Ramos (1997, p. 43)

João de Barros (1911, p.47) refere-se ao $1^{\circ}$ Jardim-Escola de Coimbra como um "tipo inteiramente à parte, e inteiramente português", que promete "desenvolver as qualidades da raça por meio de processos novos e nossos, e não transportar para Portugal quaisquer sistemas mais em voga lá fora”. Contudo, apesar de o método do poeta João de Deus constituir o fundamento pedagógico, a concepção deste Jardim-Escola absorveu traços de outros modelos europeus de ensino infantil, com os quais João de Deus Ramos contactou durante a viagem que empreendeu em 1908. Dessas visitas resultaram contactos fundamentais com diferentes métodos de ensino e pedagogos, entre os quais Friedrich Wilhelm August Froëbel (1782-1852), pedagogo alemão criador do conceito de jardimde-infância (Kindergarten), Ovide Decroly (1871-1932), pensador belga e precursor de métodos activos e do ensino não repressivo, Maria Montessori (1870-1951), médica e educadora italiana que concebeu o método baseado na observação cuidadosa das capacidades do aluno. Com efeito, o próprio João de Barros (1911, p.46) reconhece esta influência: "Já não são simplesmente as velhas salas de asilo, que nos faz esquecer a escola de Coimbra; mas os próprios Jardins de Infância, de Suíça, onde a educação, no entanto, é tão bem orientada, tão apropriada ao espírito infantil. Aqui, uma inovação se fez, e capital: o jardim que cerca o edifício é escola”.

No contexto português, este jardim-escola constitui uma conquista histórica indelével no âmbito pedagógico, na medida em que recolheu os melhores aspectos dos modelos europeus e recorre à Cartilha Maternal como método, que já tinha sido testado não só antes de ser publicado como experimentado pela superior obra das Escolas Móveis desde 1882. O próprio fundador do primeiro Jardim-Escola português reconhece os benefícios estrangeiros: "Eu repilo altivamente tudo o que seja cópia servil do que faz lá fora...sem excluir os melhores ensinamentos do estrangeiro adaptáveis em Portugal...” (apud Maria da Luz de Deus Ramos, 1997, p. 41).

Este modelo apresentava, com efeito, várias inovações, conforme reconhece João de Barros (1911, pp. 46-47):

Pelo que vi, em Inglaterra e em França, e pelo que tenho lido, sei que nunca os Jardins das Escolas Maternais tiveram outro fim que não fosse o de lugar 
para recreio; a sua função pedagógica era apenas dependente da higiene. Nada mais. Na Escola de Coimbra o jardim acumula as duas funções: - a educativa e a higiénica. E não só tem canteiros para as crianças cultivarem, como mil outras coisas de intuito pedagógico: - assim, um lago que permite a explicação da vida dos peixes e dos maquinismos dos navios; assim uma planta da cidade de Coimbra, para o estudo da geografia local, etc. Isto, é claro, sem prejuízo de um campo de jogos, e da beleza das árvores e das flores, ensinamento também indispensável para os olhos das crianças.

A adesão das camadas populares foi muito significativa, ricos, remediados e pobres, todos têm o seu lugar, conforme notou Gustav A. Bergströn (1912, p.93): “Cem, sim, são cem, pelo menos, as crianças inscritas, e teve a comissão o desgosto de verificar que outras tantas teriam vindo se outra escola houvesse."

Além do projecto pedagógico que é inerente ao jardim-escola, está também subjacente uma dimensão humana, orientando-se por fins de carácter social, visando ainda uma formação apurada ao nível da sensibilidade e do carácter. Nesta medida, o jardim-escola procura corresponder pedagogicamente à sua função através da inclusão de todas as classes sociais, tornando-se ela mesma uma pequena sociedade com as suas leis. Quanto à formação da sensibilidade e do carácter, adopta-se uma disciplina activa que permita um bom ajustamento social com vista a uma futura preparação profissional e aos valores éticos inerentes à vida activa: o respeito pelo próximo e o amor ao trabalho. No que concerne aos aspectos da pedagogia geral, são considerados dois estratos: o mutável e o imutável. Na qualidade de imutável, consta a educação sensorial e sensóriamotora, na medida em que os sentidos devem ser devidamente educados e o seu desenvolvimento orientado. Quanto aos mutáveis, são de cariz social e cultural e dizem respeito à correcção e ao alargamento do vocabulário e expressão verbal. 


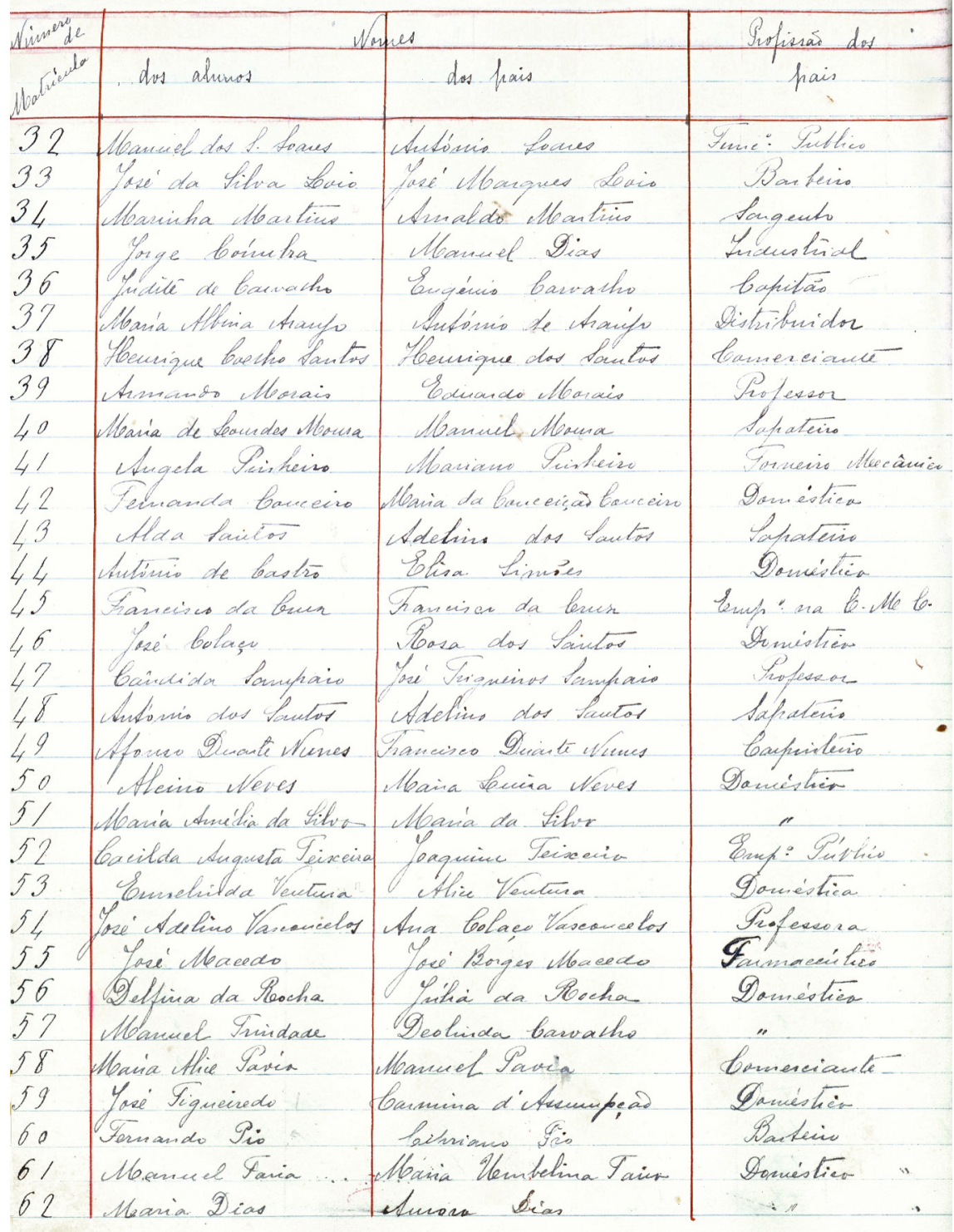

Fig.29: Livro matrícula do 1ºardim-Escola João de Deus, 1916-1917. 
Com o sucesso da fundação do primeiro Jardim-Escola João de Deus já ninguém contestava a superior necessidade e qualidade do ensino ali ministrado. Inicialmente, existiam salas separadas onde uma professora leccionava o método (Cartilha), outra a matemática e o raciocínio lógico, além de uma professora para trabalhos manuais que só ensinava esta disciplina (H. Coelho, 2010, p. 17).

Para facilitar a aplicação do ensino espontâneo, "simultaneamente racional e livre”, a graduação baseava-se na aprendizagem compatível com as idades das crianças, e organizava-se em três secções: a primeira constituída por 30 crianças, dos 3 aos 5 anos; a segunda por 26, dos 5 aos 6 anos, aproximadamente (conforme o respectivo desenvolvimento, maior ou menor, e mais ou menos normal); e a terceira, pelas restantes crianças até aos 8 anos.

A secção dos maiores e a dos médios tem cada uma a sua professora. E, inicialmente, a dos mais pequeninos, por insuficiência de recursos da Associação, seria entregue a uma vigilante, embora subordinada à direcção de uma das professoras.

Além da educação, eram ainda fornecidos bibes, utensílios escolares (sobretudo aos alunos pobres) e duas refeições diárias (almoço e merenda). Circulava ainda pela cidade um eléctrico com a indicação "Jardim-Escola João de Deus" que transportava os alunos de manhã e à tarde. Posteriormente, veio a ser substituído por um autocarro alugado aos serviços camarários.

(vide Boletim de Propaganda da Associação de Escolas Móveis pelo Método João de Deus, 1911) 


\section{Princípios elementares do Modelo João de Deus:}

- sentido social: preocupação pelo desenvolvimento das classes desfavorecidas;

- culto pelos valores nacionais;

- exaltação de um ambiente familiar pleno de amor, alegria, harmonia, serenidade e dedicação mútua;

- educação integral;

- educação sensorial, perceptiva e motora;

- respeito pelo a espontaneidade e a criatividade infantis;

- desenvolvimento gradual do raciocínio apoiado em noções concretas. 


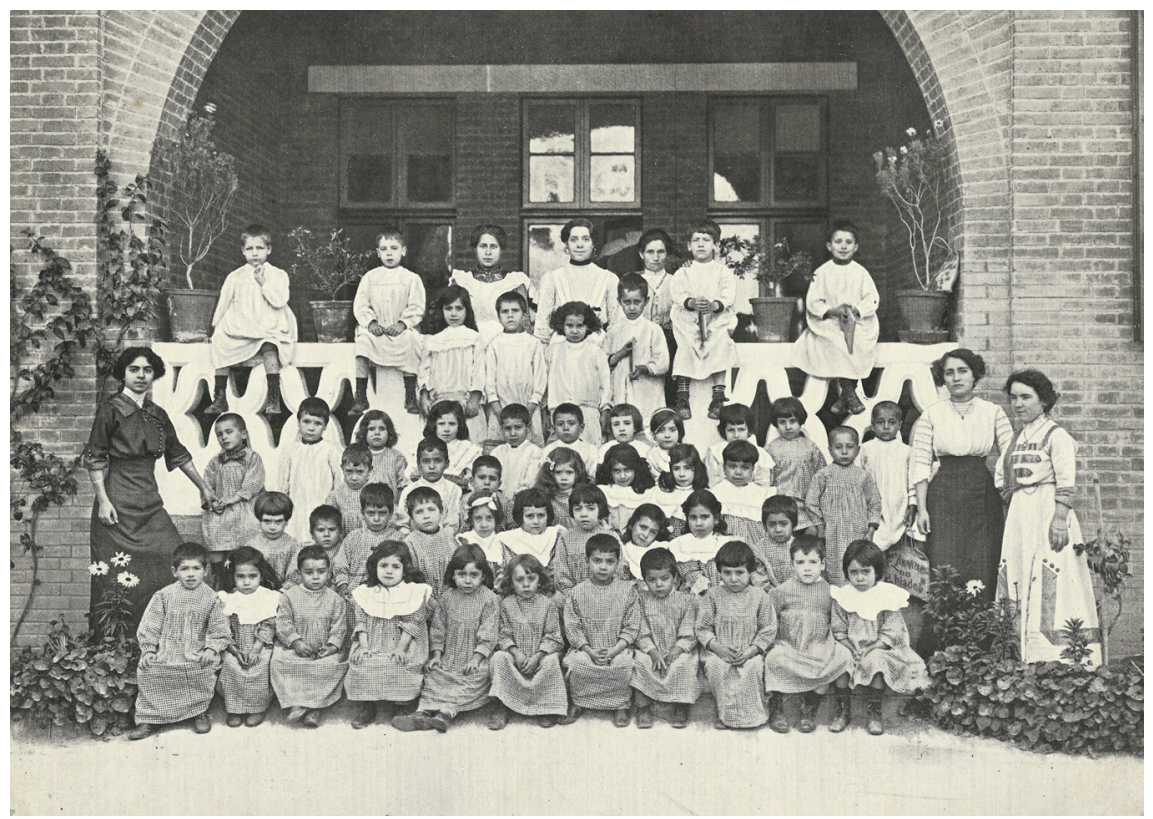




\section{Professoras Regentes do $1^{\circ}$ Jardim-Escola João de Deus}

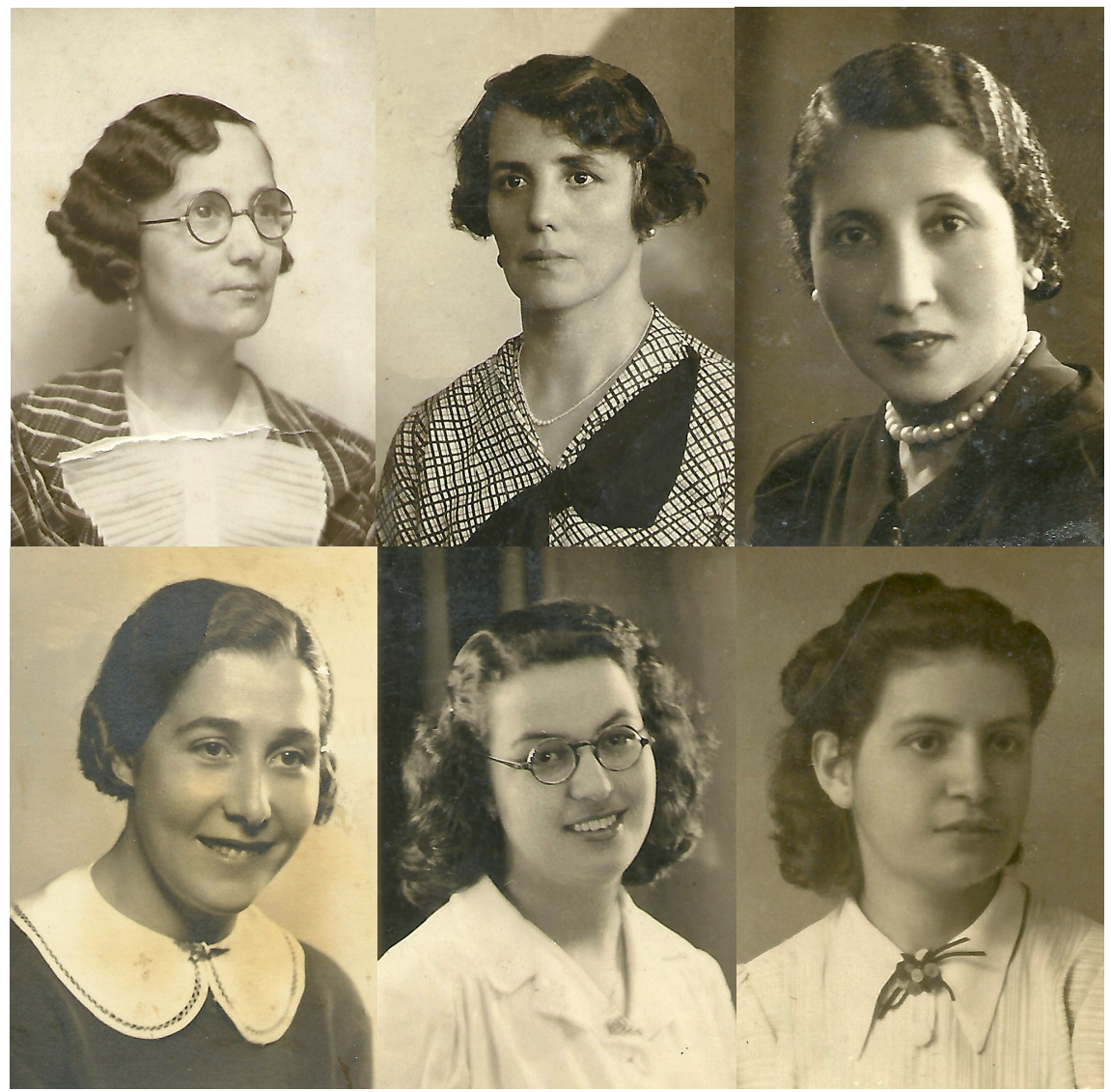

Fig.31-36: Virgínia Silveira da Mota, Mariana da Conceição Marques, Teresa de Sousa Castanheira, Cacilda Loureiro Coelho, Maria da Luz Oliveira, Maria Amélia Duarte Paiva. 


\section{Início de nomeação das Directoras Pedagógicas}

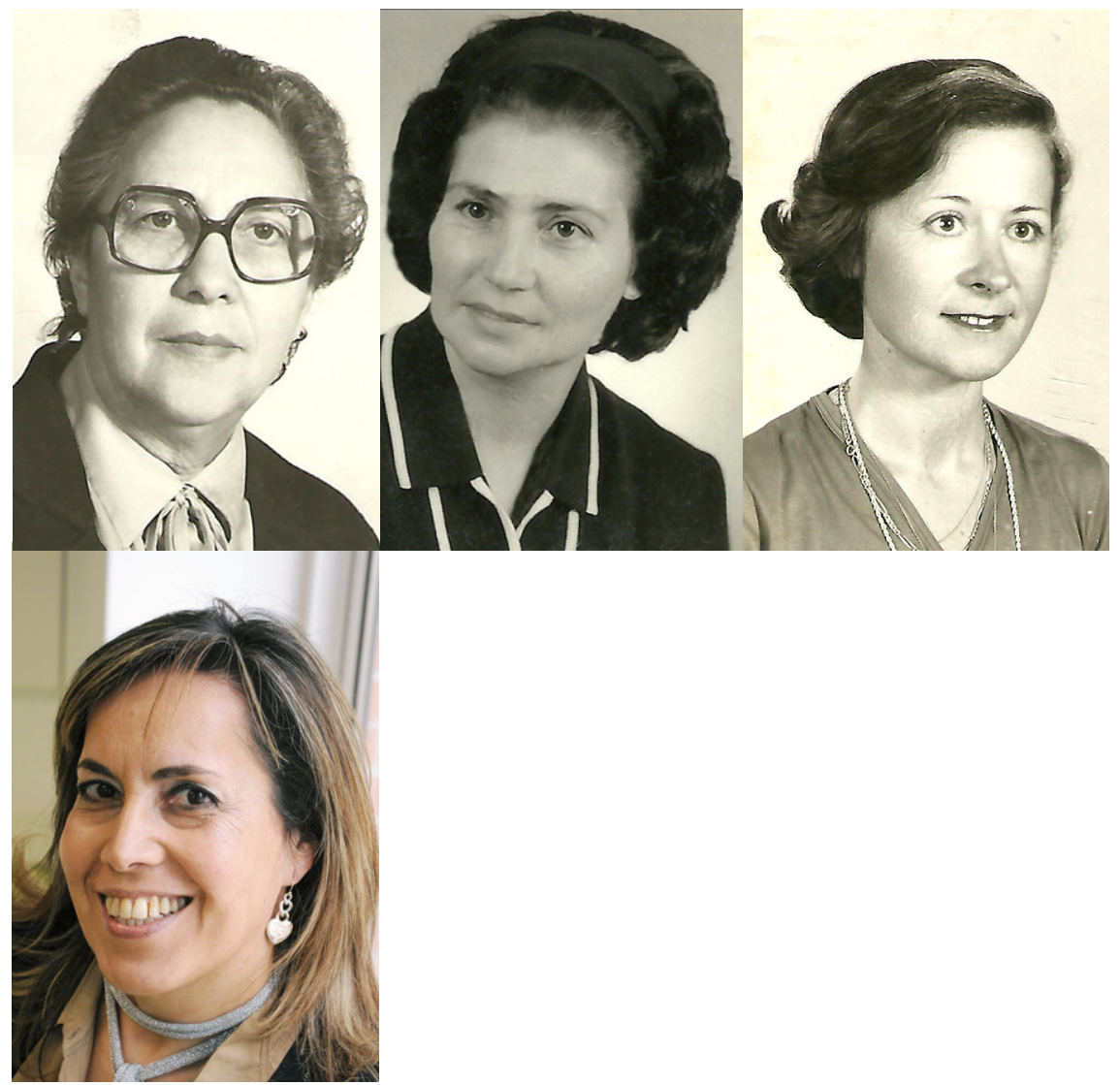

Fig.37-40: Amélia da Cunha Ramos (1954),Dirigiu o Jardim-Escola durante 26 anos. Em 1980, sai desta direcção para criar o $2^{\circ}$ Jardim-Escola em Coimbra onde continuou na qualidade de directora; Cristina Rodrigues Dinis Mónica D’Oliveira (1980); Gracinda Custódia Fernandes (1985); Maria Amélia Costa Saraiva (1987), actual directora do primeiro Jardim-Escola João de Deus. 


\section{ComemoraÇÃo do $\mathbf{5 0}^{\circ}$ ANIVERSÁrio}

\section{ASSOCIAÇÃO DE JARDINS-ESCOLAS}

\section{J O A O D E D E U S}

Completando-se no corrente mês de Abril o 50. Aniversario da fundação do 1. JARDIM - ESCOLA JOÃO DE DEUS - o de Coimbra - promoveráa a Associação de Jardins-Escolas Joäo de Deus nessa cidade no próximo dia 23 as seguintes comemoraçôes:

As 14,30 horas, uma récita infantil pelos alunos, na cêrca do Jardim-Escola.

Pelas 21,30 horas, realiza-se no Salão do Liceu D. João III, um sarau no qual usarào da palavra os Ex mos Senhores: Prof. Doutor Maximino Correia, Dr. Fernando Correia, Dr. António Joyce, Dr. Gil da Costa e José Ribeiro e que constará dum brilhante programa a executar pelo Orfeão Académico de Coimbra regido pelo ilustre Maestro Raposo Marques.

A Direcção tem a honra de convidar V. Exx. ${ }^{\mathrm{a}}$.

$A B R I L$

\begin{tabular}{llll}
1 & 9 & 6 & 1 \\
\hline
\end{tabular}

Fig.41: Convite para a celebração do $50^{\circ}$ aniversário do $1^{\circ} \mathrm{Jardim}-E s c o l a$. 
(Página deixada propositadamente em branco) 


\section{Parte II}

\section{O MÉTodo João de Deus:}

O PROCESSO DE ENSINO APRENDIZAGEM NA ARTE DA LEITURA 


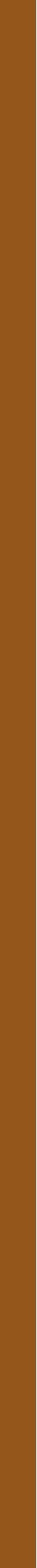




\section{O MÉTodo JoÃo de Deus:}

\section{O PROCESSO DE ENSINO APRENDIZAGEM DA ARTE DA LEITURA}

Este sistema funda-se na língua viva.

Não apresenta os seis ou oito abecedários do costume, senão um, do tipo mais frequente, e não todo, mas por partes, indo logo combinando esses elementos conhecidos em palavras que se digam, que se ouçam, que se entendam, que se expliquem; de modo que, em vez do principiante apurar a paciência numa repetição néscia, familiarizar-se com as letras e os seus valores, na leitura animada de palavras inteligiveis. Assim ficamos também livres de silabário, em cuja interminável série de combinações mecânicas não há de penetrar uma ideia!

João de Deus,

Cartilha Maternal ou Arte de Leitura, Lisboa, 1878, pp. VII-VIII 


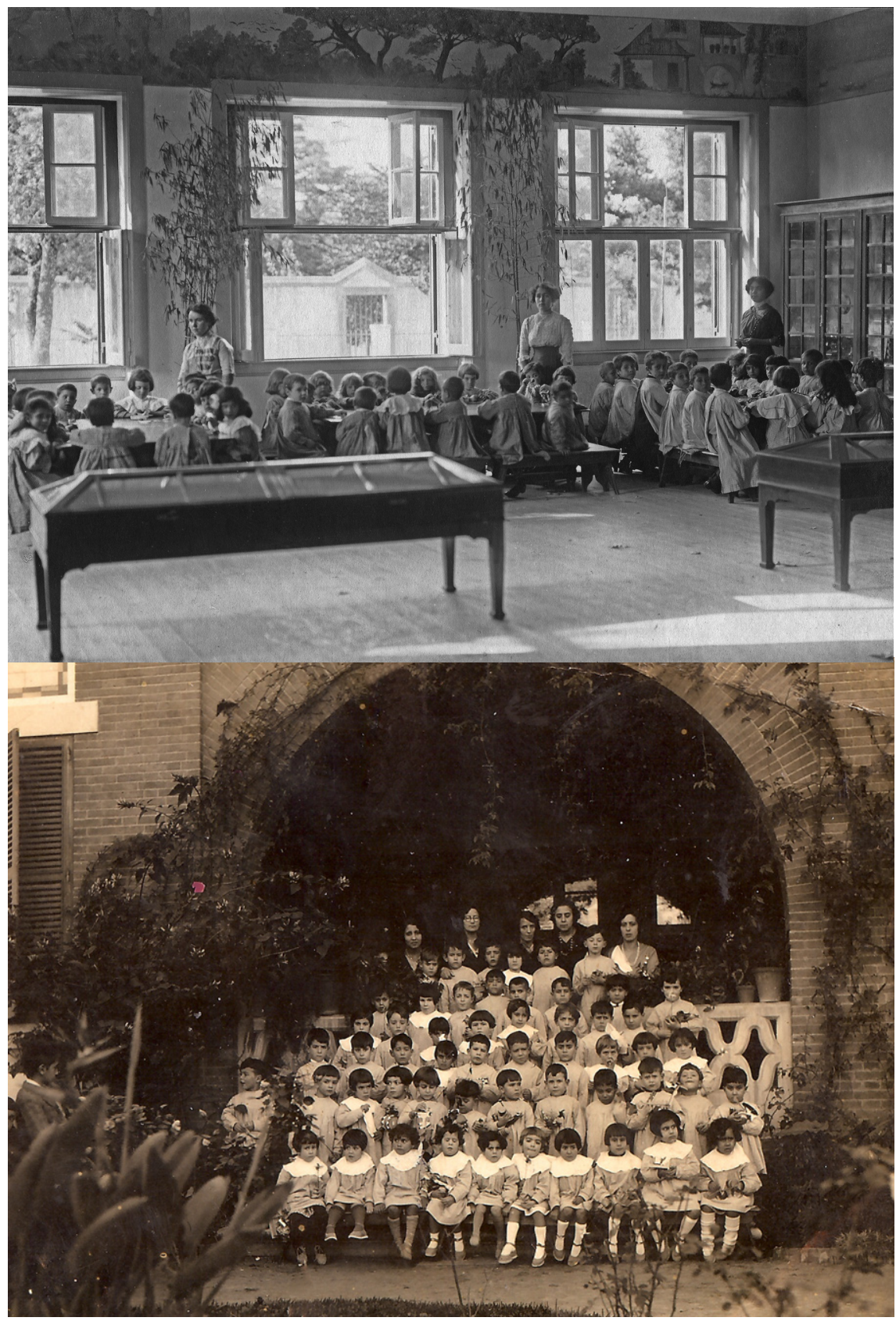




\section{O Método João de Deus}

Pelo seu carácter pioneiro, original, reformador e controverso, o método João de Deus foi alvo de vários estudos e despertou o interesse de muitos curiosos. Todos os que sobre ele se debruçaram sentiram-se seduzidos pela sua teorização psicopedagógica, pela consistência do processo ensino-aprendizagem, pela sua integralidade de conhecimentos, pela conjugação da tradição com a modernidade, pelo alcance social de um programa propedêutico, que preconizava um ideal (per) formativo do homem - humanístico, poético, sentimental. Nesse sentido, podemos cerzir os vários olhares e convergir as múltiplas perspectivas na caracterização do método, que neste primeiro dos centenários apresenta uma reconhecida vitalidade. 


\section{JOÃO DE DEUS

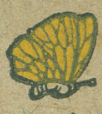 \\ ARTE DE ESCRITA}

\section{PRIMEIRO CADERNO}

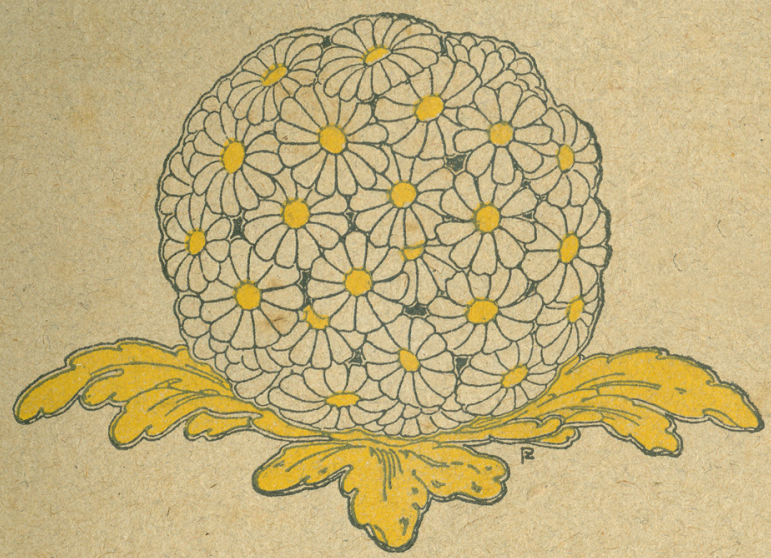


MÉTHODE J. DE DEUS

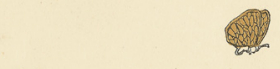

A B C MATERNEL

ART DE LECTURE

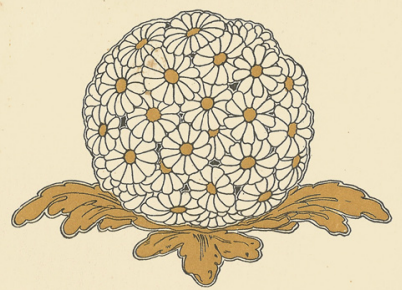

\section{DONS DE FROËBEL}

ÉDITION D'ESSAI

JOÃO DE DEUS

\section{Cartilha Maternal ou}

\section{Arte de Leitura}

SEGUNDA PARTE

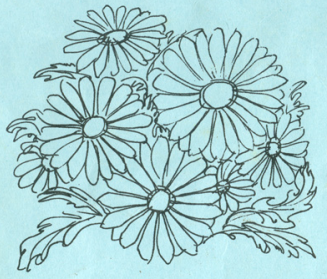

LIVRARIA BERTRAND

LIS B OA
JOÃO DE DEUS RAMOS

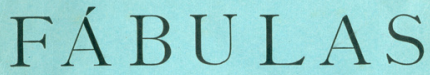

PARA GENTE MOÇA

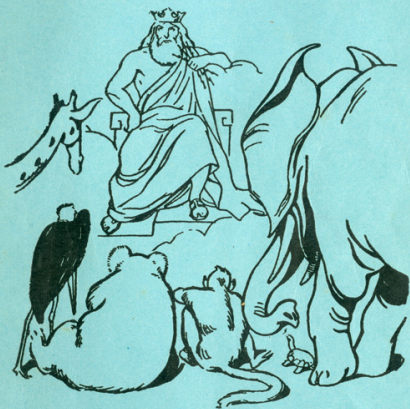

LIVRARIA BERTRAND LISBOA

Figs.5-8: João de Deus, Méthode ABC Maternel, Art de Lecture, Édition s'essai - Imprimerie Nationale, Lisbonne, 1920; Caderno "Jardim-Escola João de Deus", Dons de Froëbel, 1960-1961; João de Deus, Cartilha Maternal ou Arte de Leitura - segunda parte, Lisboa, 1971; João de Deus Ramos, Fábulas para gente moça, Bertrand, Lisboa, [1955]. 


\section{JOÃO DE DEUS \\ PEDAGOGO \\ MODERNO}

\section{JOÃO DE DEUS}

E O RECADO
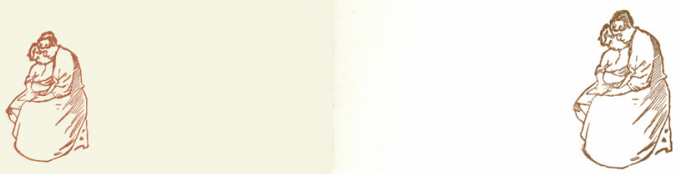

LISBOA

1979

LISBOA — MCMLXXXXII

DO

MÉTODO DE JOÃO DE DEUS

A

LA PÉDAGOGIE

FORMAÇÃO DE EDUCADORES

DE INFÂNCIA

DE JOÃO DE DEUS RAMOS

(1878/1953)
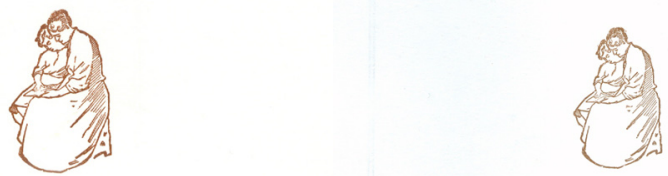

LISBOA - MCMLXXXVI

ANTONIO DE DEUS RAMOS PONCES DE CARVALHO

Figs. 9-12: Henri Campagnolo, João de Deus Pedagogo Moderno, Museu João de Deus, Lisboa, 1979; Matilde R. Araújo, João de Deus eo Recado, Palestra proferida no Jardim Escola João de Deus em Faro em 8 de Março de 1986; Arquimedes Santos, Do Método de João de Deus à Formação de Educadores de Infânncia, Lisboa, 1986; A. Ponces de Carvalho, La pédagogie de João de Deus Ramos (1878-1953), Lisboa, 1990. 
ÊLÉMENTS POUR L'HISTOIRE

D'UNE ÉCOLE DE FORMATION DES

INSTITUTEURS DE MATERNELLE
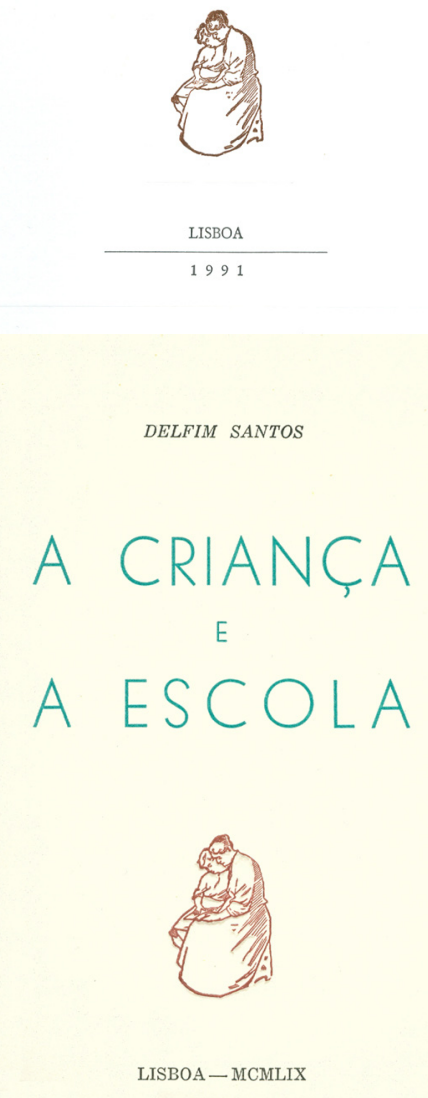

1991

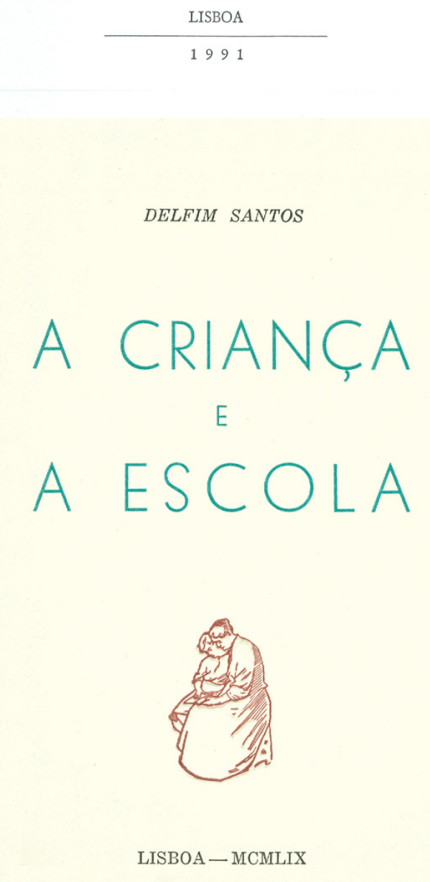

João de Deus

e a actualidade do seu método

ou Arte de Leitura*

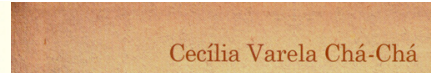

Cecília Varela Chá-Chá

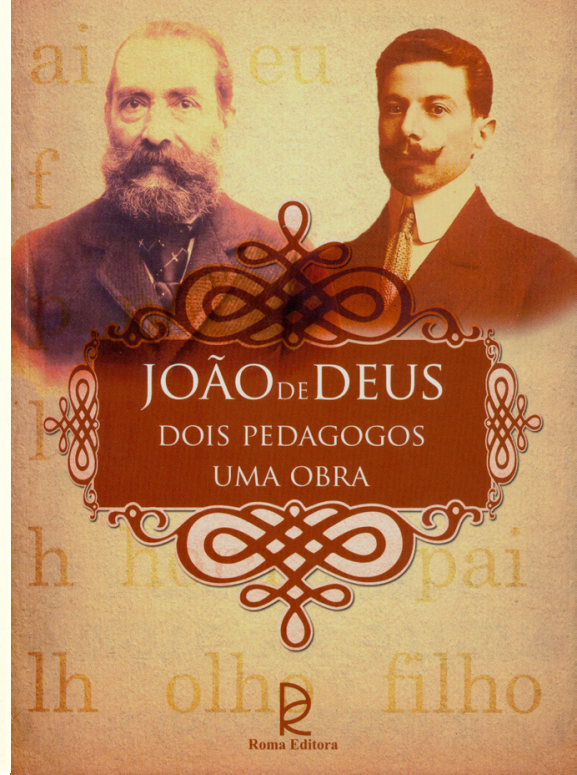

Figs.13-16: A. Ponces de Carvalho, Éléments pour l'histoire d'une école de formation des Instituteurs de Maternelle, Lisboa, 1991; A. Maria Mira, João de Deus e a actualidade do seu método ou Arte de Leitura, Lisboa, 1995.; Delfim Santos, A Criança e a Escola, Lisboa, MCMLIX; C. Varela Chá-Chá, João de Deus: Dois Pedagogos uma obra, Lisboa, 2009. 


\section{MotivaÇões E EXPECTATIVAS Do PROJECTO}

Apesar dos seus muitos inimigos, este novo sistema, analítico e intuitivo, mereceu os aplausos da maioria dos educadores progressistas e tornou-se uma espécie de bandeira para os propagandistas culturais republicanos.

Maria da Luz de Deus Ramos (1982, p.2)

"A tarefa em que se empenhou activamente o Dr. João de Deus Ramos enquadrava-se num cenário de analfabetismo que, nessa época, ultrapassava os $70 \%$, chegando mesmo a haver freguesias que não possuíam escola primária. As preocupações pedagógicas de João de Deus Ramos, prolongando o pensamento e o ideário de seu Pai, não se circunscreveram apenas à alfabetização e ao ensino da leitura e da escrita, ou, melhor dizendo, estes objectivos filiavam-se na intenção primordial de educar, ou seja, de formar, moral e espiritualmente, o ser humano, intenção que João de Deus Ramos actualizou ao longo da sua vida e na obra que legou ao País (...). A criação do $1^{\circ}$ Jardim-Escola João de Deus constituiu uma medida de extraordinário alcance social e pedagógico e representou uma tentativa, bem sucedida, de implementar um modelo de educação infantil em Portugal. Com efeito, o modelo proposto desde logo, pretendeu estabelecer uma instituição aberta a todas as camadas sociais e que tivesse em conta a inserção no meio português, sem prejuízo de uma projecção universalista” (N. de A. Vasconcelos Raposo, 1991, pp. 5-7).

"O Jardim-Escola João de Deus constitui um tipo inteiramente à parte e inteiramente português, pois nela se tentarão desenvolver as qualidades do homem por meio de processos novos e nossos, incentivando um desenvolvimento gradual do raciocínio, apoiado sempre em noções concretas. Há quarenta anos João de Deus formulou e defendeu estes princípios, há vinte que eles vão sendo explicados pelo pedagogismo estrangeiro" (João de Barros, 1991, p. 47).

“...devemos envidar esforços para erguer e criar institutos de feição própria, que se harmonizem com a índole e as tradições da nossa gente, sem exclusão formal das soluções pedagógicas universalmente adoptáveis ou adaptáveis. Embora ao longo da história da Educação Infantil tenha havido alguma flutuação dos objectivos, accionada pelas próprias instituições, - ora de natureza mais social, ora de natureza e pendor mais educativos, na base esteve sempre a ideia de que os fins da educação pré-escolar estão centrados numa perspectiva de desenvolvimento harmónico das potencialidades da criança, encarada esta como um ser educável e destinado a atingir uma personalidade responsável e livre na sociedade" (N. de A. Vasconcelos Raposo, 1991, p. 7). 
Num contexto em que se valorizava não só a cultura popular, como o combate ao analfabetismo, seguindo as teorias inovadoras da Psicopedagogia, os Jardins-Escolas João de Deus vêm prosseguindo os objectivos específicos da préescolaridade. O método praticado nos Jardins-Escolas João de Deus fornece às crianças a preparação para uma boa escolaridade, pela estimulação de competências no domínio verbal. Aliado à promoção das competências comunicativas e linguísticas, a iniciação à leitura, a partir dos cinco anos e meio, vai constituir uma importante actividade estimuladora do desenvolvimento cognitivo, segundo a ortodoxia do método da Cartilha Maternal. Numa apreciação insuspeita e objectiva da Doutora Carolina Michaëlis de Vasconcelos, reconhece-se nesta arte da leitura pontos inovadores, como o desenho tipográfico das letras e a abolição da soletração que refinaremos mais adiante. Assim, os objectivos dos JardinsEscolas não se confinam ao âmbito cognitivo-linguístico, estendem-se a outras actividades lúdicas, sensoriais, estéticas e de interacção social, constituindo um modelo funcional de educação infantil, ao encontro das actuais teorias da Psicologia Genética e da Psicopedagogia.

Integrado nos curricula estavam disciplinas como ginástica, francês e música - décadas de 40 e 50, bem como Inglês, Ballet e Informática - na década de 80 - ou ainda Expressão Dramática na década de 90. O desenvolvimento do perfil de competências, a aquisição proficiente dos conhecimentos nos vários domínios visava uma integralidade (per)formativa do indivíduo para que desempenhasse na sociedade um papel activo e interventivo. 

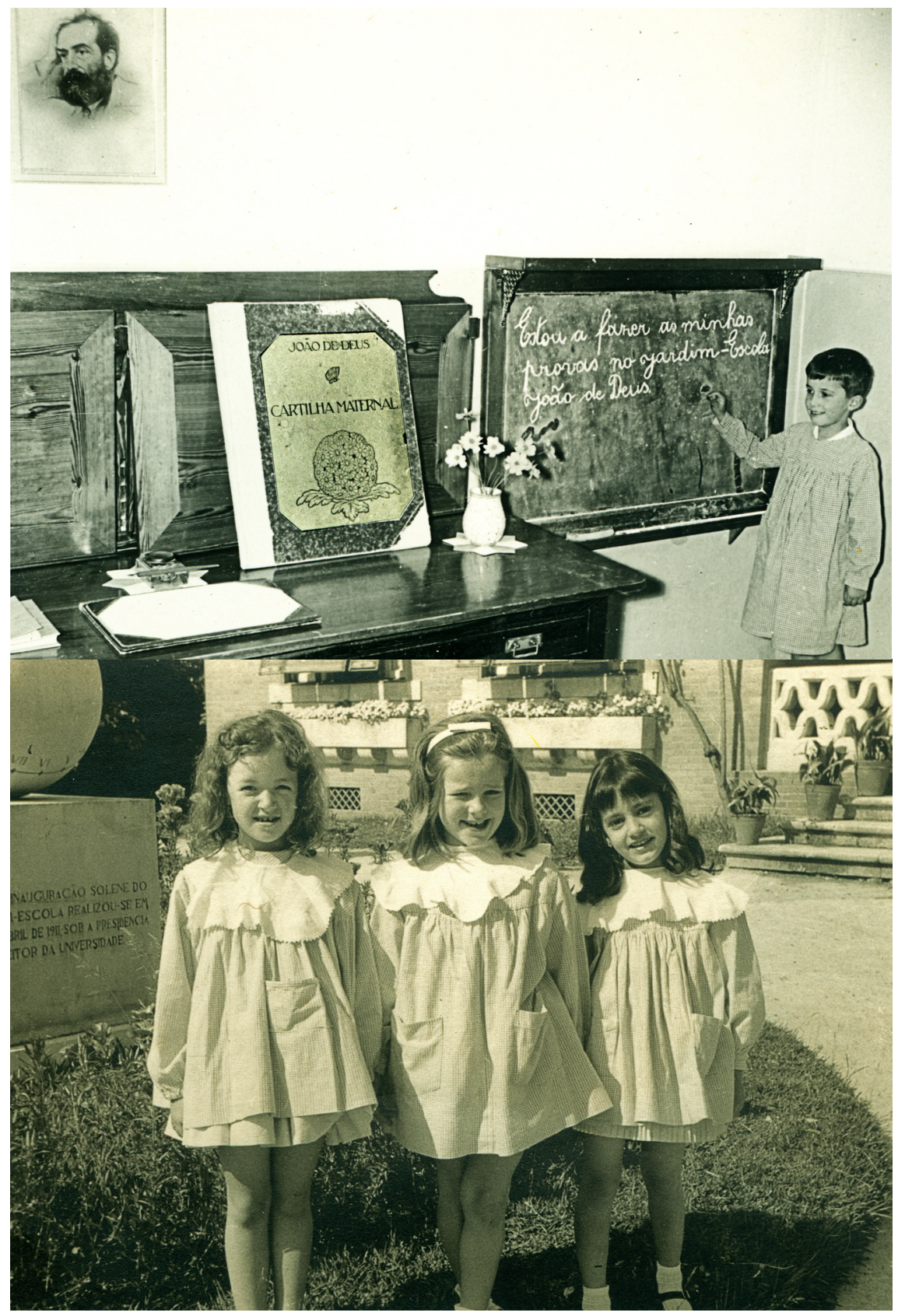

Fig. 17: António Meliço Silvestre a prestar provas no $1^{\circ}$ Jardim-Escola.

Fig. 18: Crianças no recreio no pátio da escola. A primeira menina (a contar da

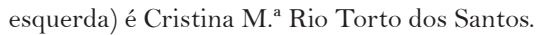




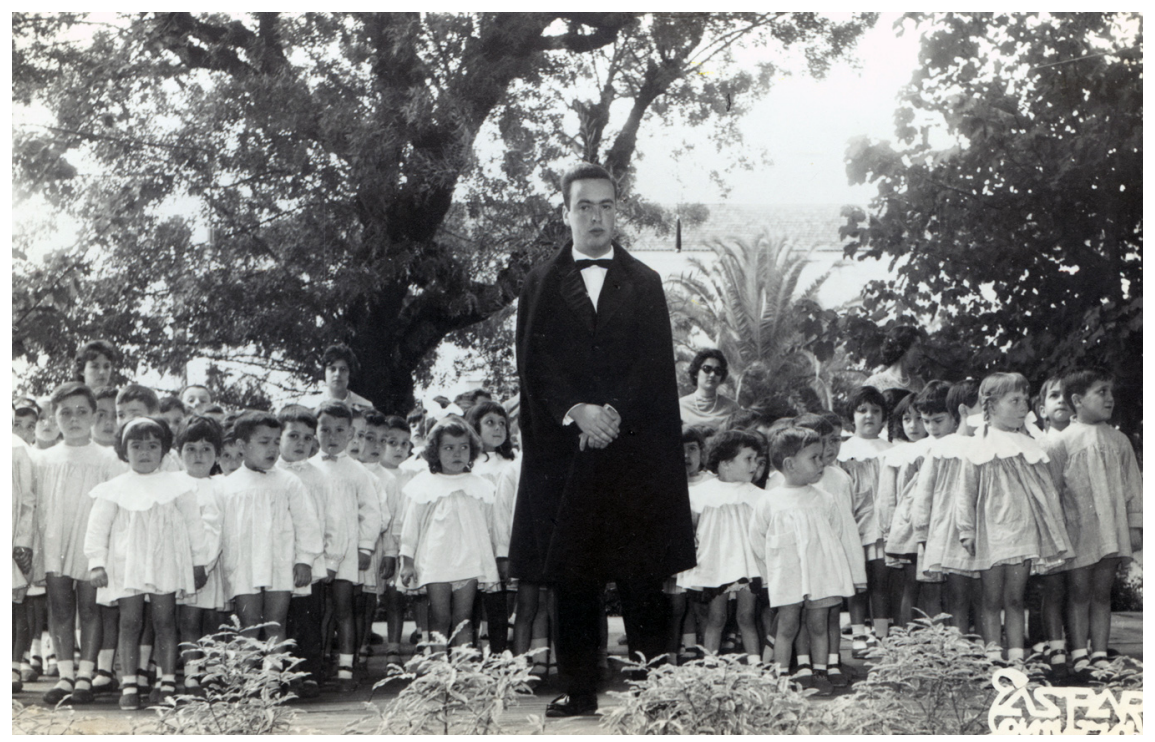

Fig. 19: Classe de crianças com um aluno universitário. 


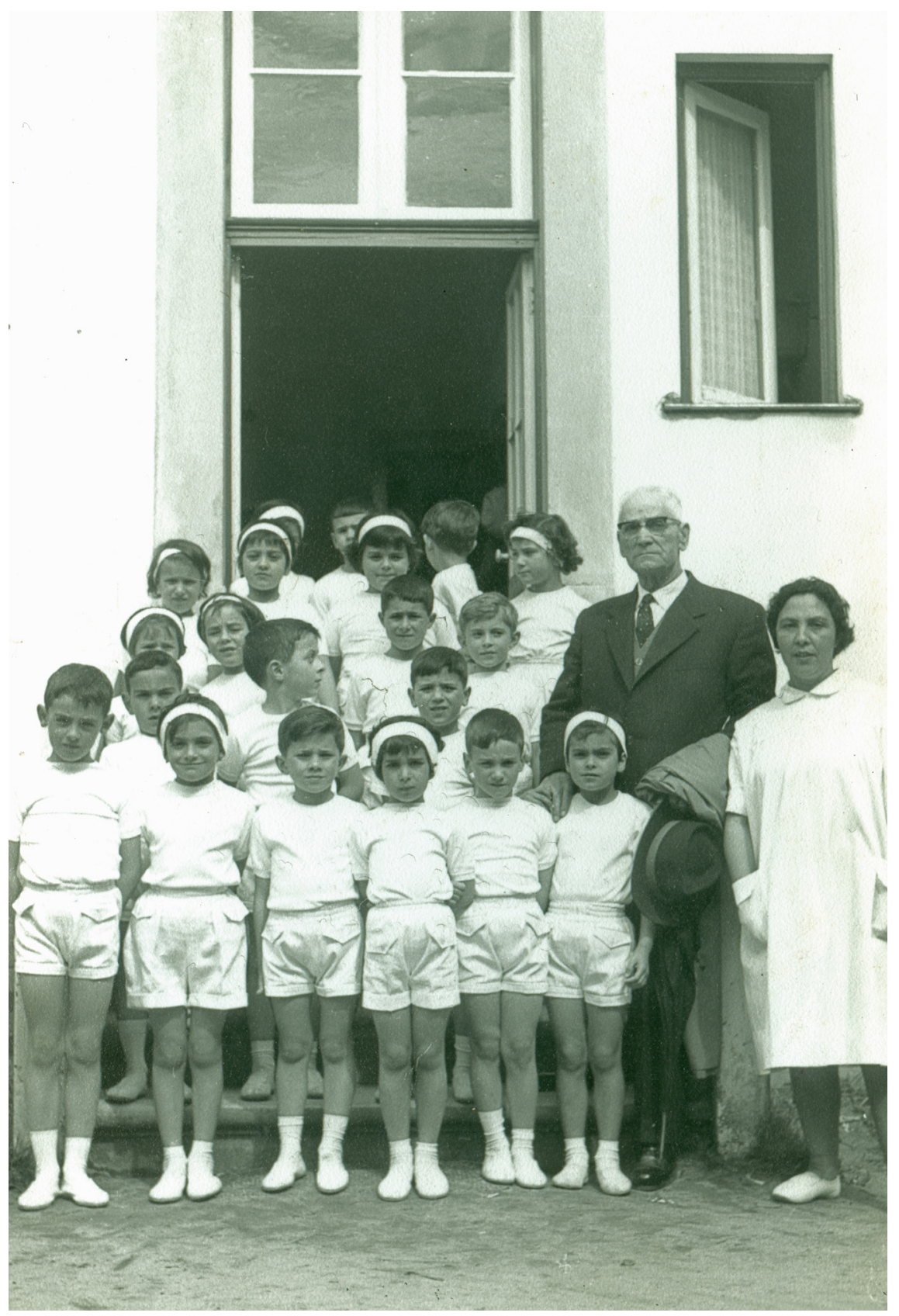




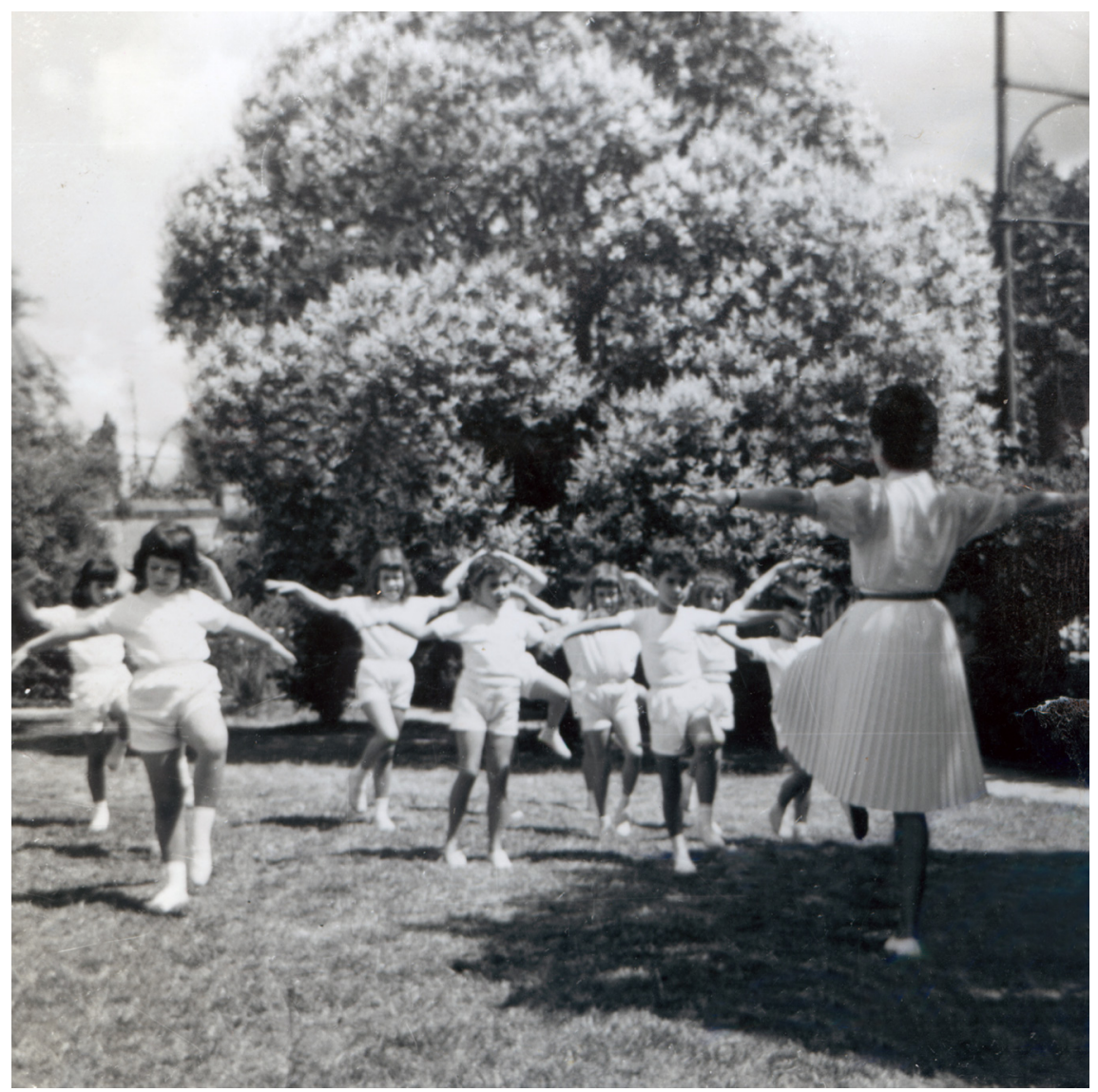

Fig. 21: Crianças na aula de ginástica. 


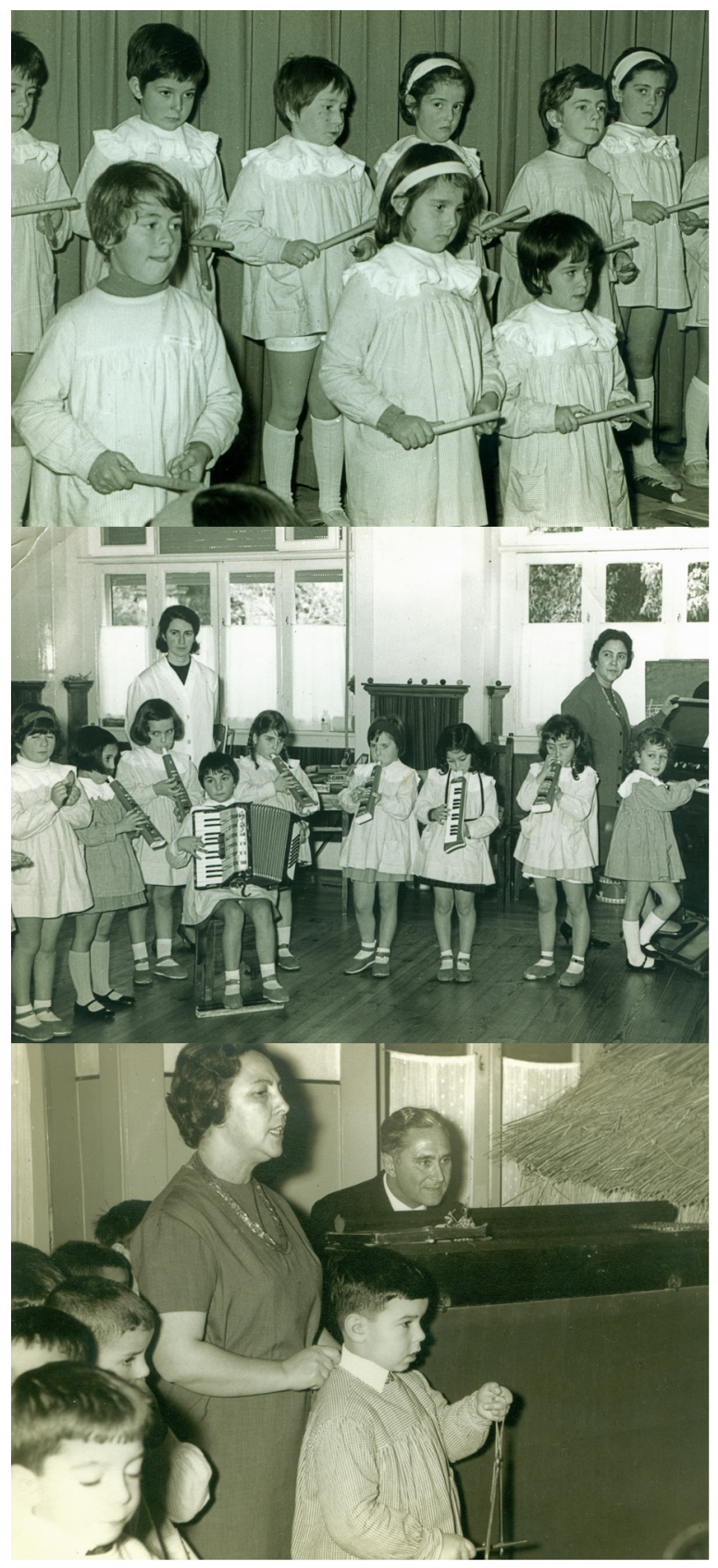

Fig.22: Crianças numa aula de música e canto.

Fig. 23: Crianças em aulas de formação musical. Fig.24: Crianças em exercício musical. 


\section{A Cartilha:}

\section{ACTUALIDADE E UNIVERSALIDADE Do MÉTODo}

"Encontramo-nos numa época política agitada que estiola e anula toda a acção construtiva, mormente em tais assuntos que carecem de plano, boa orientação, continuidade e persistência”... Desenvolvia-se nessa época uma forte campanha contra a Cartilha Maternal, escrita por meu pai. A Cartilha Maternal foi, por assim dizer, o cordão umbilical da minha vida de educador. Trata-se de um método de ginástica de raciocínio que desenvolve a reflexão contra o espírito da superficialidade....o que importa não é ensinar depressa, é ensinar bem" (J. de Deus Ramos apud G. Brosque, 1950, p. 17).

João de Deus dedicou-se oito anos à elaboração do método da Cartilha Maternal ou também conhecido como Arte de Leitura, um trabalho pedagógico que confessa dirigir às mães, assumindo-o no Jornal das Senhoras, em Fevereiro de 1877: "em princípio, as mães que nos ensinam a falar é que nos deviam ensinar a ler pois a fala é a língua da família...”. Este poeta-pedagogo dava aulas em Lisboa, pelo seu método desde 1875 , a crianças, a adultos e a professores gratuitamente como sempre foi seu apanágio, na senda desta certeza "para ser bom filho há que ser amanhã bom cidadão e acima de tudo viver em sociedade importa saber ler”. Precursor da pedagogia moderna, João de Deus surpreende pelo seu carácter destemido e lúcido, na antevisão de modernos princípios de psicologia como a impreteribilidade de considerar o indivíduo na sua globalidade e diferenciação. Outro vector basilar é igualmente o bem-estar afectivo da criança, na harmonia circundante.

"A Cartilha Maternal, como sabem, foi publicada em 1876 [1877]. Há, portanto, mais de um século! Talvez por isso, muitos espíritos apressados caiam, facilmente, na tentação de, sobranceiramente, a regalarem para o rol das velharias. Talvez esses espíritos não disponham de conhecimentos suficientes para compreenderem a modernidade dos seus postulados. O seu principal fim foi iniciar praticamente uma corrente nacional e nacionalizadora do ensino, ao mesmo tempo que se definia bem o lugar e o valor do método João de Deus na escola portuguesa. Era pouco? Era, sem dúvida. Mas era alguma coisa. Era uma obra a caminho” (A. Maria Mira, 1995, p 5).

Os textos narrativos da Cartilha apresentam uma simbologia adaptada à noção da educação integral do indivíduo designadamente, a sensibilização pelo exemplo e pelos factos da vida, uma educação que radica nos valores matriciais e alia a ética e a estética. 


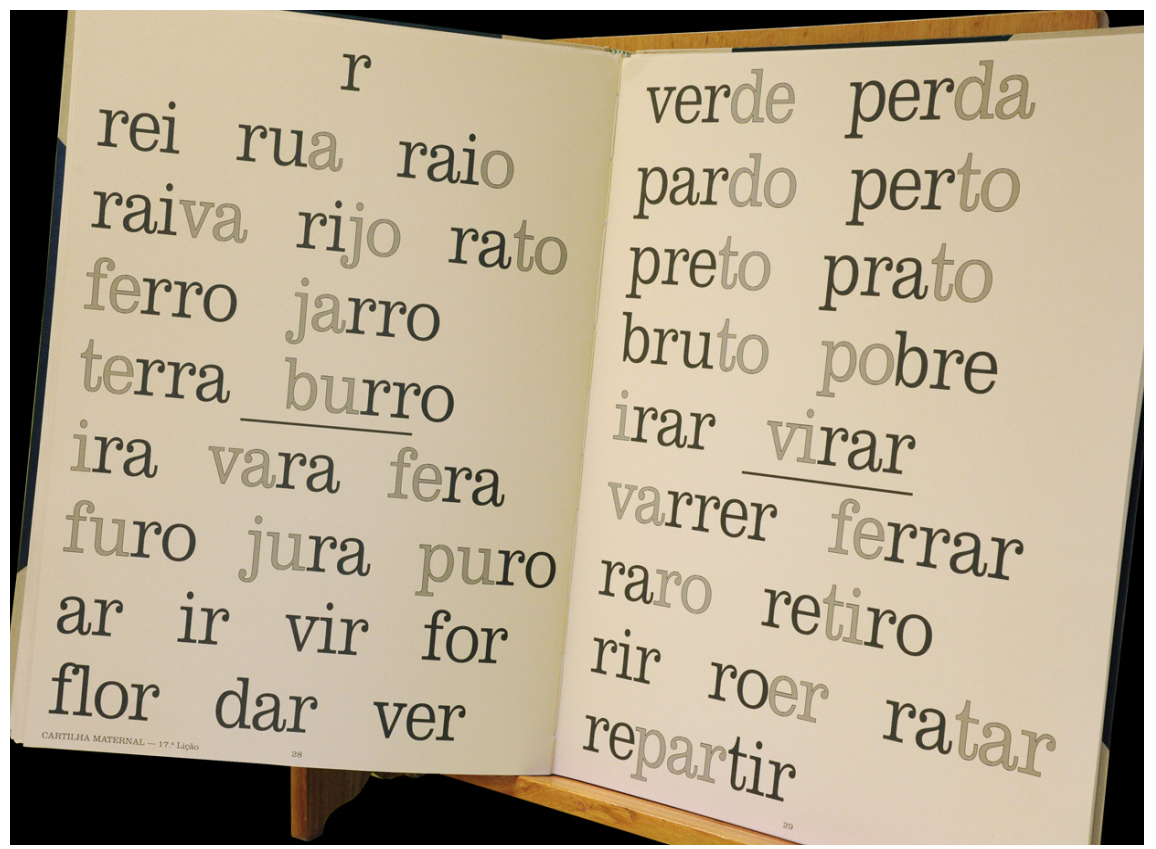




\title{
Tradição e modernidade do mÉtodo João de Deus
}

\author{
João de Deus afirmava que a Cartilha Maternal e o método não \\ devem ser confundidos 'a Cartilha é o livro, é o corpo sem alma' e o \\ método é a alma, o espírito e a interpretação da Cartilha.
}

M. da Glória Saraiva (2003, p. 143)

Constataram os professores, e estamos no século XIX, que uma importante percentagem de crianças se revelava incapaz de aprendizagens, sobretudo no âmbito da escrita e da leitura. Pretendendo compreender e explicar esse fenómeno, os psicólogos Binet e Simon elaboraram uma escala psicométrica em 1905, os primeiros testes psicológicos. Como confere R. Zazzo (apud A.M. Mira, 1995 p. 7), os psicólogos e pedagogos viram nesses resultados matéria para questionarem os instrumentos que utilizavam bem como os seus próprios conhecimentos sobre a criança e sobre condicionamentos sócio-culturais. Foram evidenciando as seguintes conclusões: $1^{\circ}$ que existia uma importante correlação entre aprendizagens escolares e a origem social das crianças; $2^{\circ}$ que existia a mesma correlação entre aprendizagens escolares e linguagem; $3^{\circ}$ que os métodos pedagógicos utilizados não eram os mais adequados para essas crianças, sobretudo no que se referia à aprendizagem da leitura e da escrita; $5^{\circ}$ que os conhecimentos sobre o desenvolvimento da criança eram insuficientes, o que impulsionou movimentos científicos vindouros, no âmbito da psicologia do desenvolvimento (afectivo, cognitivo, instrumental) e da psico-patologia, nos domínios da linguística e da psico-linguística, da pedagogia e da psico-pedagogia. Esses conhecimentos vieram progressivamente modular e modernizar a percepção e a compreensão do funcionamento da criança, as práticas pedagógicas, a organização pré-escolar e a escolar e a formação dos próprios professores.

"Porque o método João de Deus foi concebido numa época afastada, poderá haver quem o considere como arcaico e ultrapassado. No entanto, certos aspectos deste método não condizem com tal apreciação, em especial, a sua recusa de tratar as sílabas independentemente das palavras em que estão inseridas. Esta característica distingue-o radicalmente dos antigos métodos de soletração, contra os quais se insurgem a justo título os defensores do 'método global”' (H. Campagnolo, 1979, p. 7).

É precisamente contra o tradicional método mecânico de ensino da leitura, pela soletração, desprovida de sentido e de reflexão, que João de Deus se posiciona. Ouçamo-lo: 
Há duas soletrações, a antiga e a moderna. A soletração antiga vai chamando as letras pelos seus nomes, para apresentar depois, não a soma desses nomes, mas a soma dos valores dessas letras. Esta soletração é absurda e desmoraliza o raciocínio do principiante. A verdadeira palavra do homem é a palavra escrita, porque só ela é imortal. Enquanto o ensino da palavra escrita é o encanto de mães e filhos, o ensino da palavra escrita é o tormento de mestres e discípulos. Há de haver meio facílimo, grato, universalmente acessível, de espalhar essa arte, ou antes faculdade, sem a qual o homem não passa de um selvagem. Esse meio ou esse método não pode ser essencialmente diferente do método encantador pelo qual as mães nos ensinam a falar, que é falando, ensinando-nos palavras vivas, que entretecem o espírito e não letras e sílabas mortas, como fazem os mestres. Pois apressemo-nos também a ensinar palavras e acharemos a mesma amenidade... Lêde-as e nunca soletreis." (apud Ana Maria Mira, 1995, p. 12).

Este método veio introduzir uma dimensão estética na apresentação das letras, dos ditongos, das sílabas, das palavras e sobretudo uma dimensão afectiva estimuladora do desenvolvimento cognitivo, já que a criança não vê as letras descarnadas e frias, desligadas das palavras e desprovidas de sentido, aprendidas numa lenga-lenga, que apenas faz apelo à sua capacidade visual e de memorização de segmentos gráficos. Pelo contrário, a criança começa a conhecê-las imediatamente por afinidade às palavras que ouve, que os seus familiares utilizam para lhe explicarem o mundo à sua volta. Num primeiro nível reconhece, desde logo, que há uma correspondência entre a produção fonética e a significação desse mesmo enunciado, a conjugação inalienável do conteúdo e da sua forma. Assim, promove-se o entendimento e a intuição na criança para o facto da língua ter as suas valências e operações a vários níveis, num processo de gradual abstracção.

No método global, a má distinção dos morfemas em relação aos semantemas implicam um recorte pouco claro do valor das palavras como utensílios linguísticos. Tudo isto parece vago e de pouca importância, mas não o é no desenvolvimento de uma lógica infantil em formação. Terá que haver um maior cuidado, como dizia João de Deus Ramos, pedagogo filho do poeta "que essa espiral vai do aprender a falar ao aprender a ler.” Aos pais e aos educadores caberá a linha primária dessa espiral e um correcto desenvolvimento da fala. A criança que fala mal apresentará dificuldades para ler. Neste sentido é muito necessário um estímulo e correcção verbal, bem como uma propedêutica bem orientada para se iniciar um trabalho com êxito e ao mesmo tempo do gosto da criança. 


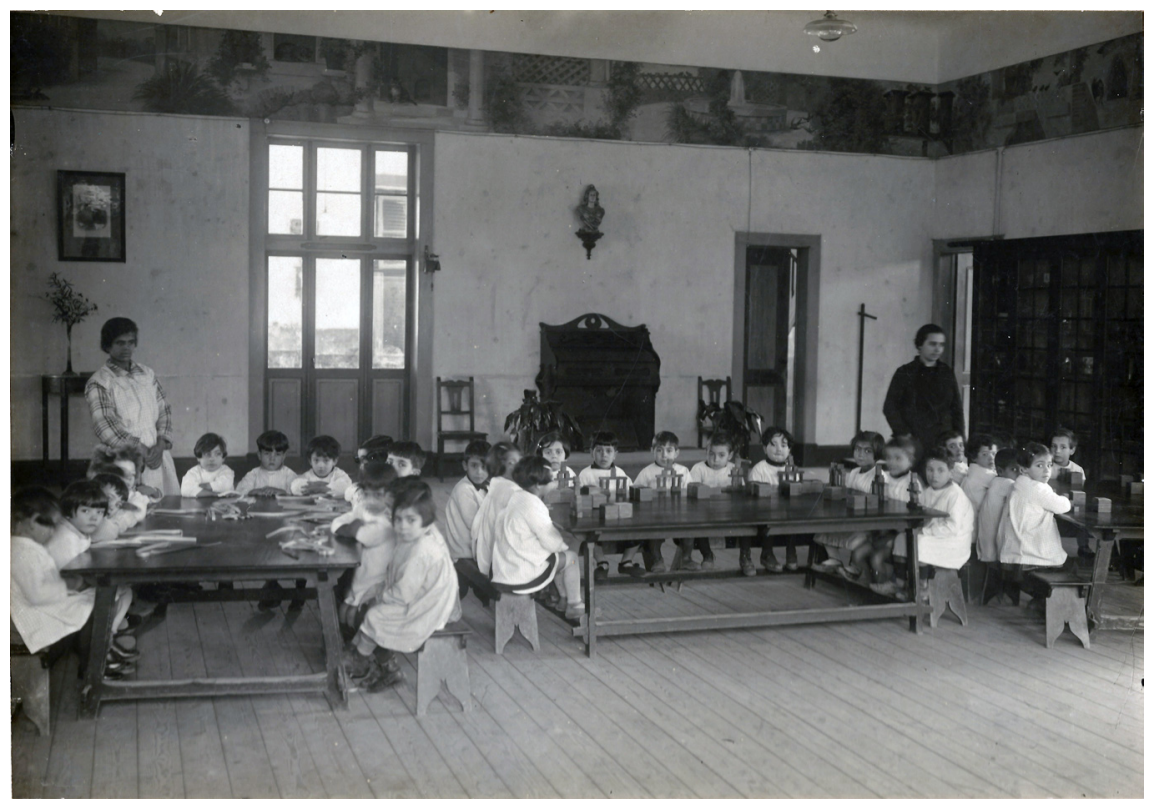

Fig. 26: Grupo de crianças no salão com duas educadoras, aprendendo com os dons de Froëbel e com tiras de papel (1913). 


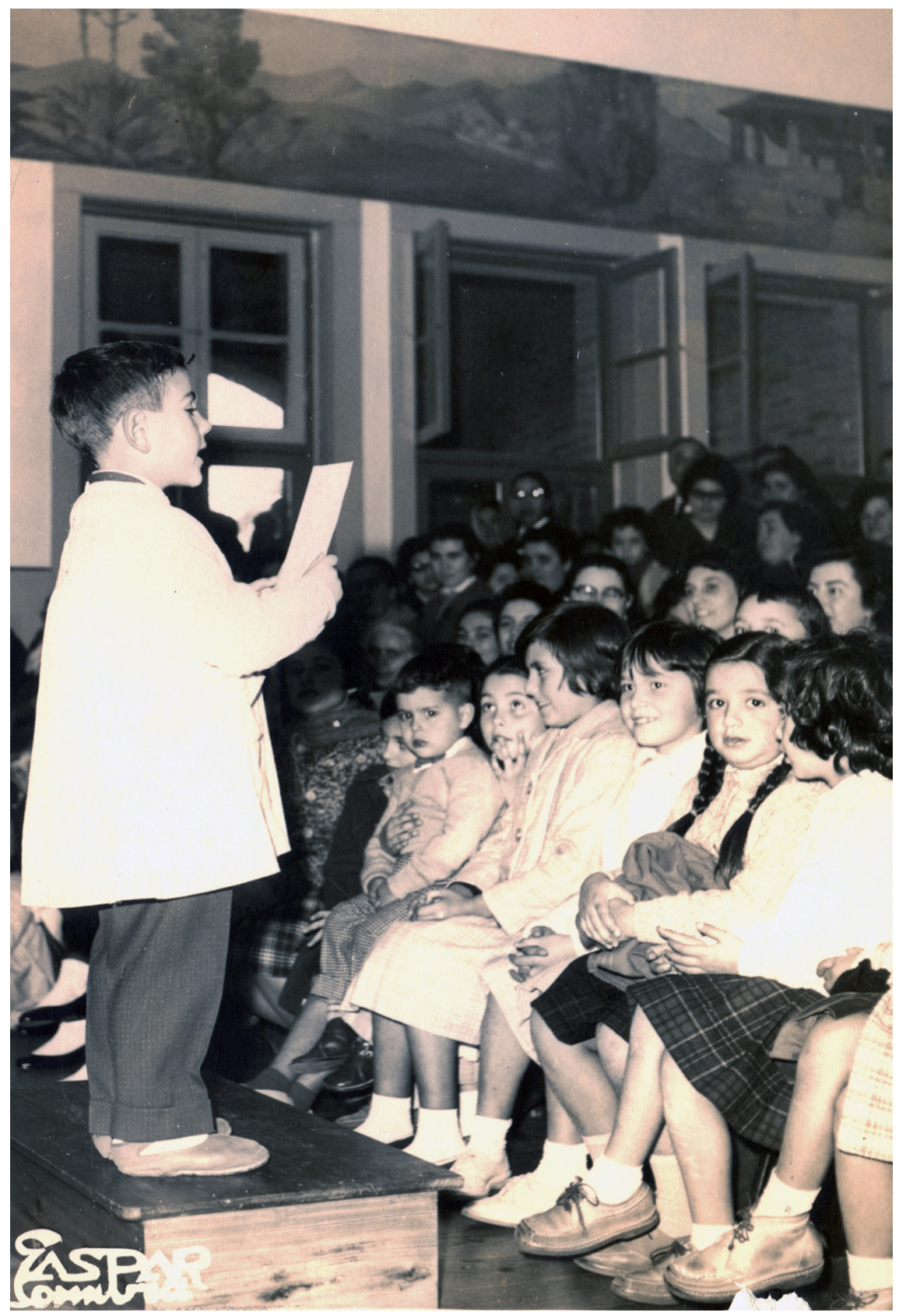




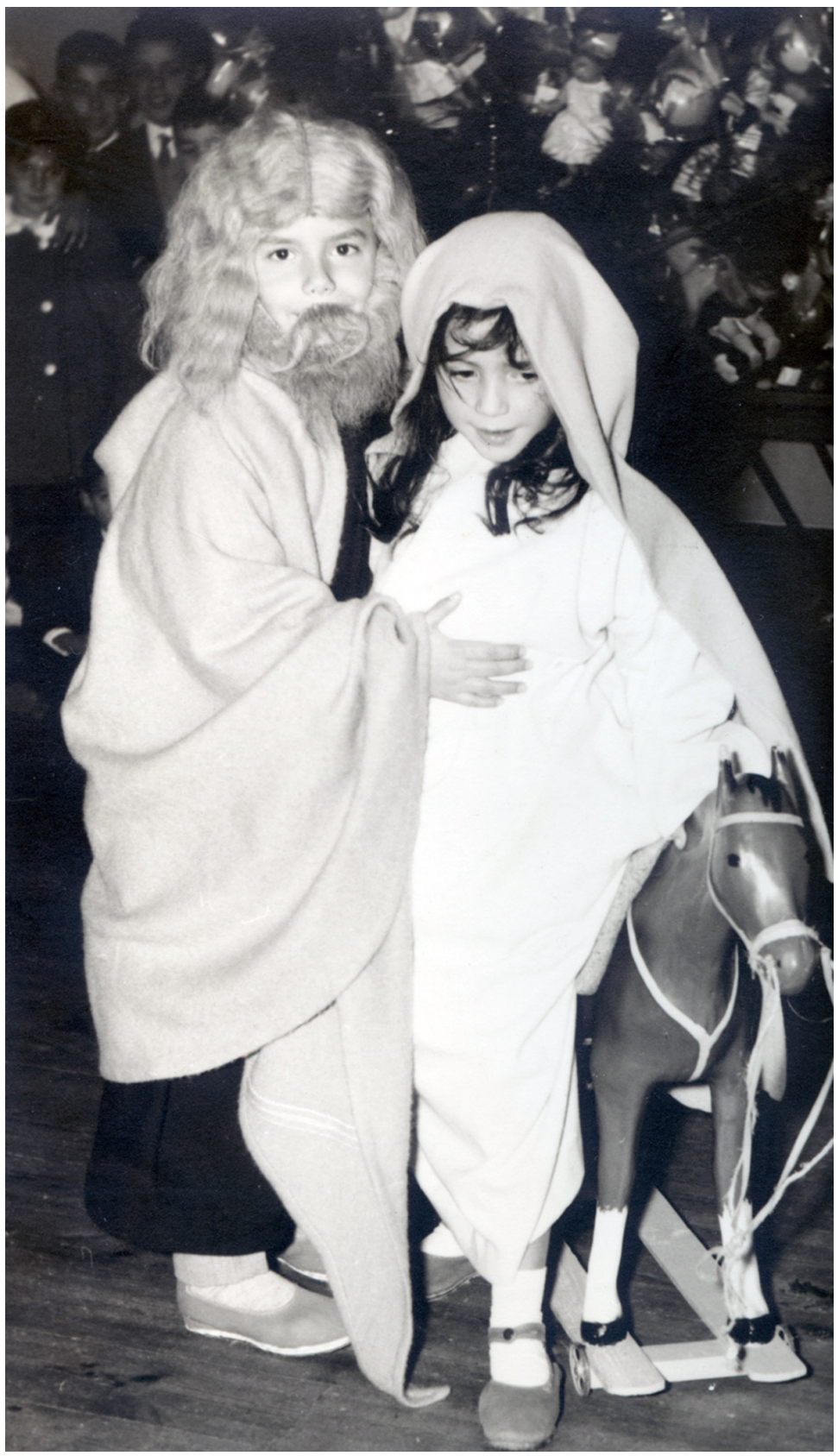

Fig. 28: Actuação de crianças em oficinas de expressão teatral. 

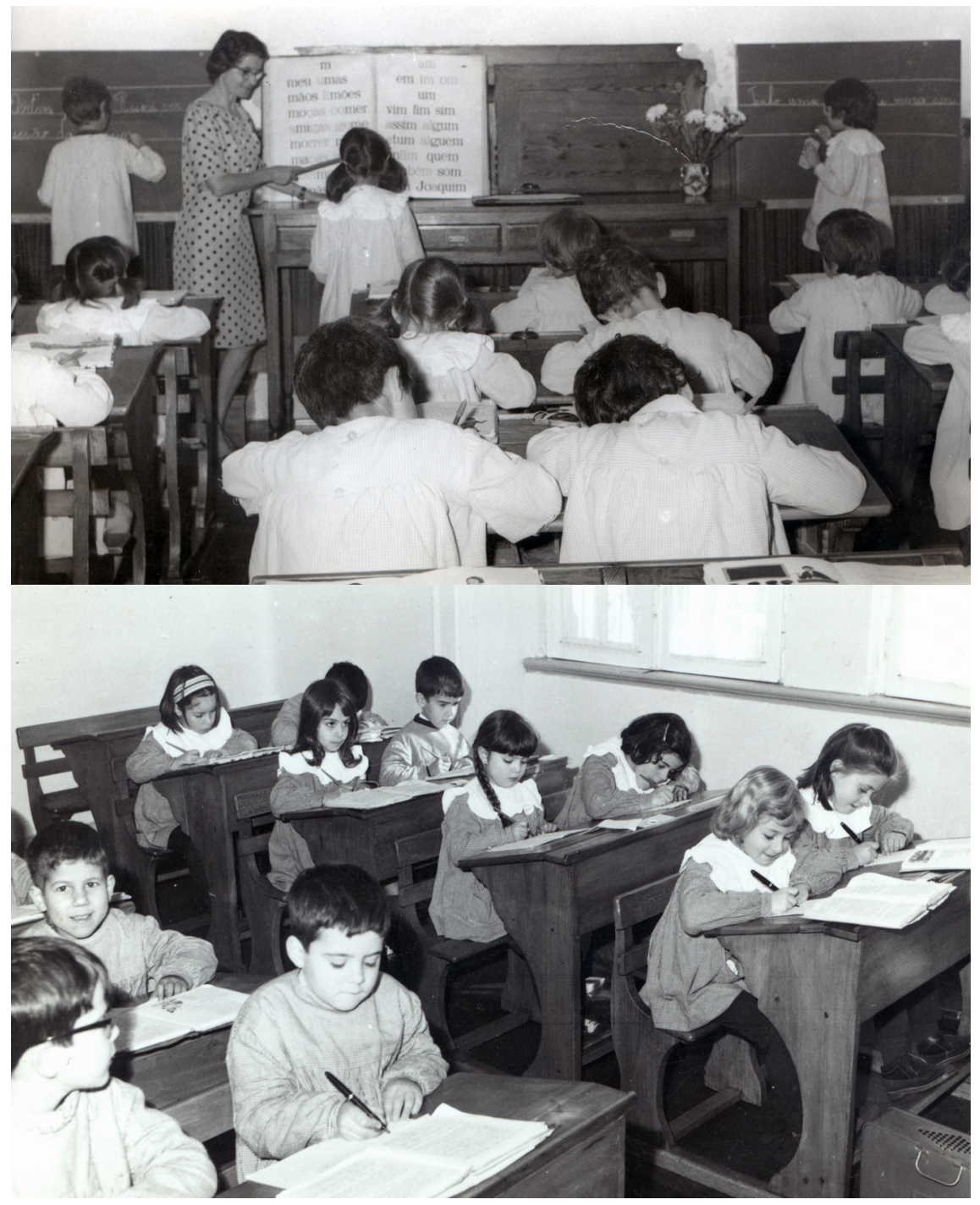


\section{Os biBes do Jardim-Escola Jõ̃o de Deus}

Os bibes, pressupondo a diferenciação por classe, constituem uma marca do Jardim-Escola João de Deus, desde a sua fundação. Além dos bibes eram ainda disponibilizados utensílios escolares diversos, sobretudo aos alunos pobres, bem como duas refeições diárias - almoço e merenda -, garantindo a ricos, pobres e remediados um lugar. O uso do bibe garante assim o plano de igualdade material entre os alunos, na medida em que não há espaço para ostentações. Apenas o esforço e a dedicação podem ser critério de valorização. Além dos bibes de uso diário e frequente, o Jardim-Escola estabelece ainda o uso de fatos específicos para o exercício físico. Note-se que a configuração do bibe está especificamente pensada para a necessidade da criança, por exemplo os vários bibes da secção pré-escolar têm um bolso na parte frontal para que a criança possa guardar o respectivo brinquedo ou boné. 

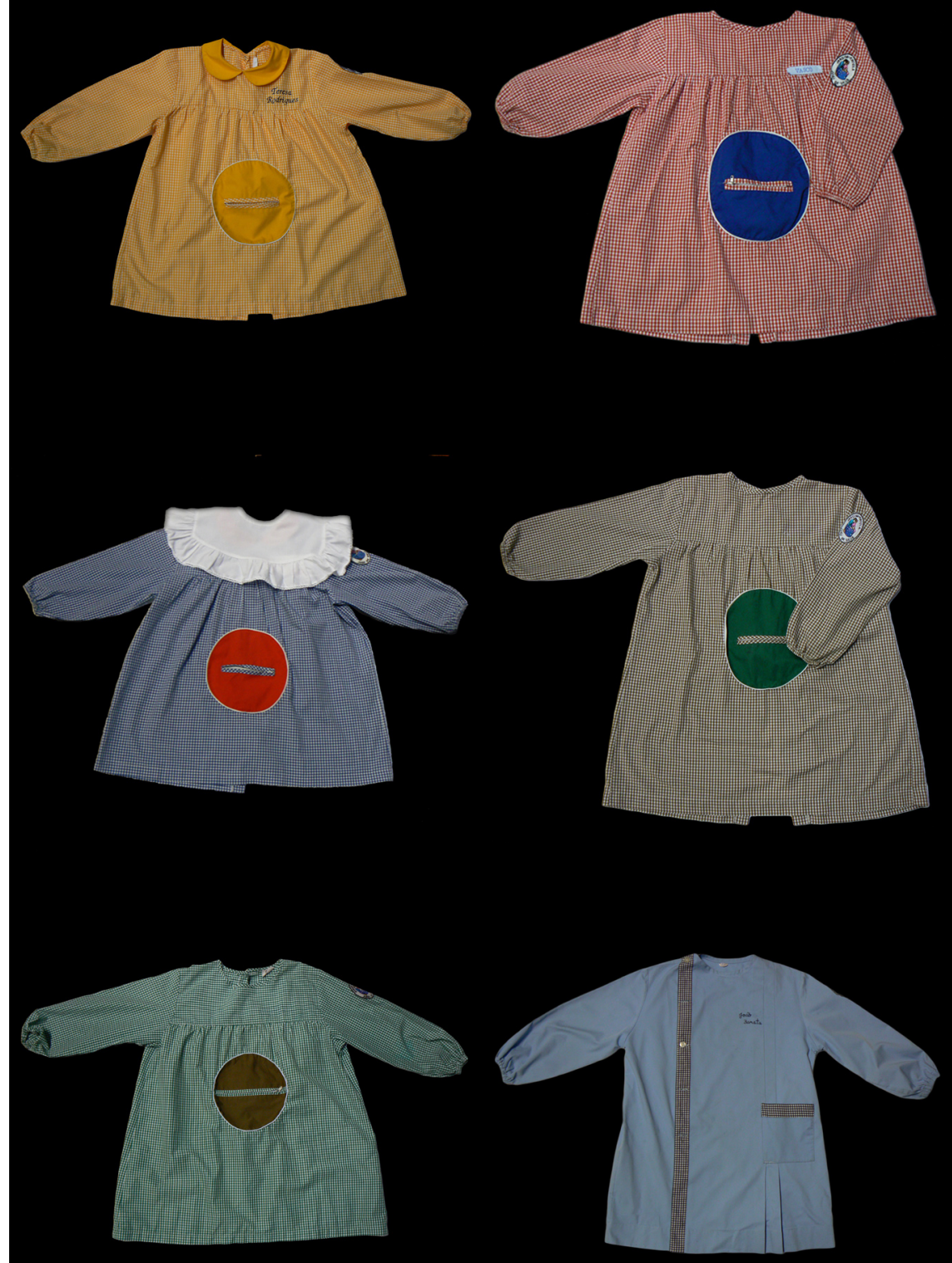

Fig. 31-36: Bibe amarelo (3 anos), versão menina; Bibe vermelho ( 4 anos), versão menino; Bibe azul ( 5 anos), versão menina; Bibe castanho ( 6 anos), versão menino; Bibe verde ( 7 anos), versão menino; Bibe azul claro (8 anos), versão menino. 


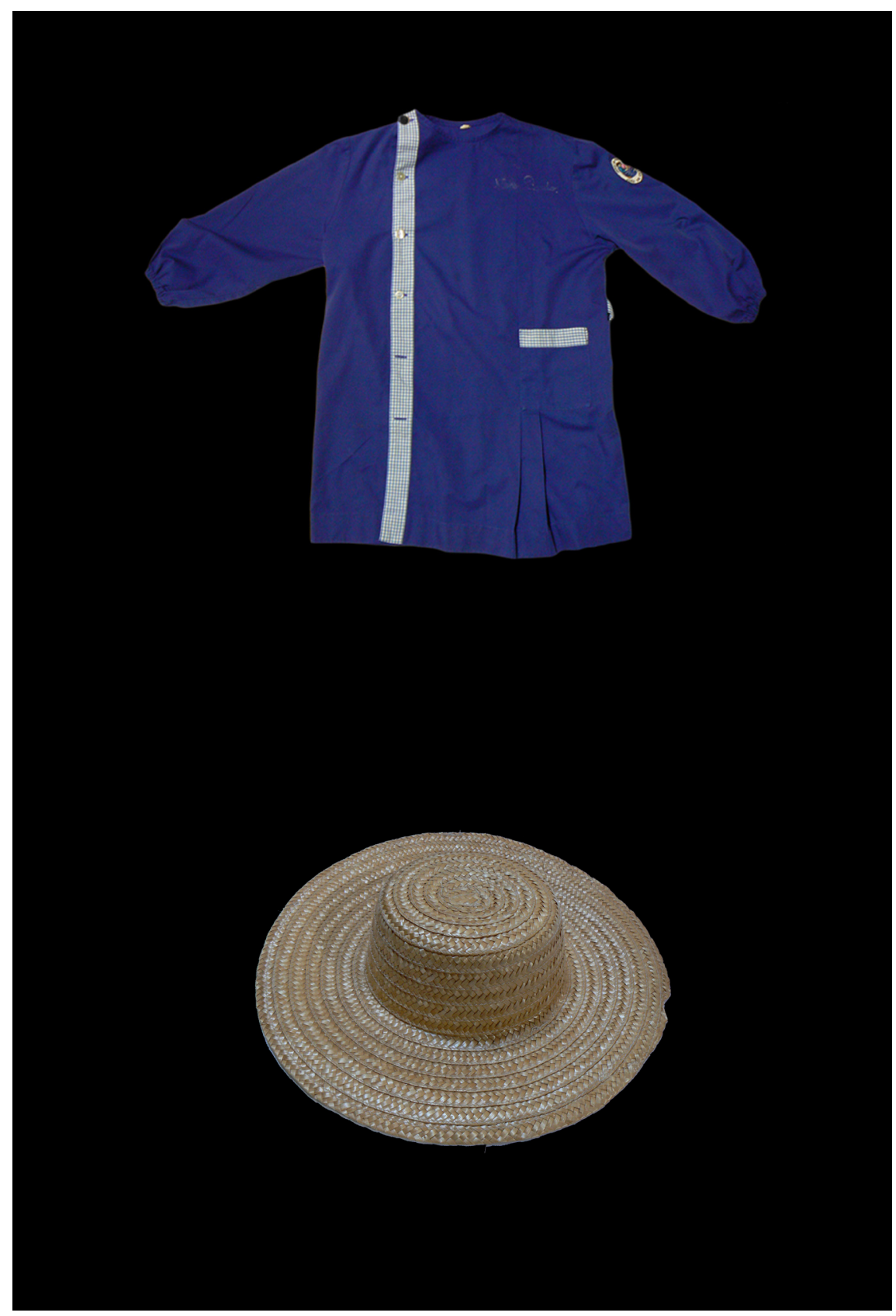

Fig. 37: Bibe azul escuro (9 anos), versão menino.

Fig. 38: Chapéu de Sol. 


\section{Os fundamentos linguísticos do Ensino da Leitura}

O Método João de Deus é um método racional, analítico, de rigor científico muito ligado à língua portuguesa e pregnante em toda a nossa cultura.

Inicia-se aos cinco anos na maior parte dos países da Europa. A criança tem grande satisfação quando aprende a ler e revela muito gosto e alegria durante os exercícios de leitura (...). São quase inexistentes os casos de dislexia. João de Deus Ramos preconizou sempre que a $1^{\circ}$ fase primária (antigas $1^{\mathrm{a}}$ e $2^{\mathrm{a}}$ classe) deveria ser orientada de uma forma maternal, e portanto, integrante nos seus Jardins-Escolas. (...) Este critério é muito importante para evitar rupturas e desadaptações escolares. Critério semelhante é seguido na Suíça, em Genève, onde as professoras são preparadas para orientar os alunos dos 4 aos 7 anos. (...). Um facto que devemos assinalar é o de que quase não há insucesso escolar, ou se surge é em percentagem mínima. Dentro do ritmo de cada um, todos os alunos ficam a ler no espaço de alguns meses. A criança vive uma infância calma, alegre e feliz, mas adquire também amor ao trabalho que encara como um jogo sério e compensador na estruturação de bons hábitos, que permitirão seguir sem problemas a sua vida escolar. (Maria da Luz de Deus Ramos, 1982, p. 7 adaptado). Desta forma, M. da Glória Saraiva (2003, p.141) reitera a ideia afirmando que a aprendizagem da leitura surge como algo muito importante, sendo desde cedo feito um trabalho de preparação para a realizar; as actividades propostas, desde que a criança entra no Jardim-Escola, vão no sentido de a preparar para novas aprendizagens. Assim, quando uma criança ouve ou conta histórias, repete lengalengas, trava-línguas faz exercícios de lateralização e estruturação espacial ou constrói manualmente qualquer objecto, está a fazer propedêutica para a leitura (...) a criança vai reconhecendo os suportes gráficos, interiorizando e compreendendo a correspondência entre os símbolos e a sua significação, percepcionando a importância da leitura. Maria da Luz considera que através da aprendizagem da leitura inicia-se o desenvolvimento do raciocínio associativo."

A leitura pode ser considerada como um processo fundado na aptidão do leitor em estabelecer associações directas entre o sentido, a expressão gráfica e a expressão fónica dos componentes significativos - palavras e construções gramaticais - das mensagens linguísticas, seja qual for o sistema de representação gráfica, ou "código escrito", que a língua utilize. Em contrapartida, a aprendizagem da leitura depende estreitamente da natureza do código escrito: a simplicidade da aprendizagem é em função da simplicidade do código escrito. O primeiro factor de simplificação de um 
código escrito é o pequeno número das suas unidades - os grafemas - elementos gráficos mínimos sucessivos que se repetem nas mensagens escritas, como os ideogramas e as letras. Convém notar que o método global pode igualmente ser caracterizado pelo facto de tentar promover no aprendiz, e desde o início da aprendizagem, as associações ternárias - sentido/expressão gráfica/expressão fónica - de que ele necessita no decurso da leitura corrente. Este método converte-se num estímulo de aprendizagem na medida em que é imediatamente tangível a finalidade do ensino e os benefícios da leitura corrente, a leitura de fragmentos textuais. Reconhecido o papel fundamental que a assimilação do código escrito desempenha na evolução regular e contínua da aprendizagem da leitura, cabe-nos ainda observar que os códigos alfabéticos podem apresentar uma complexidade variável consoante as línguas, ou, por outras palavras, que as correspondências entre os grafemas e as unidades fónicas exigem referências a um contexto. É indispensável por conseguinte, analisarmos, cuidadosamente, o sistema das unidades fónicas - unidades distintivas de uma língua antes de determinarmos quais os grafemas complexos que deverão ser assimilados pelo aprendiz, de forma a que a sua inserção no inventário dos grafemas simplifique as referidas correspondências entre o plano gráfico e o plano fónico da língua.

Por forma a comparar mais comodamente os diferentes métodos de ensino da leitura, utilizaremos a seguinte terminologia:

- associações básicas: as primeiras associações estabelecidas dentro do processo do ensino da leitura, entre as faces fónica, semântica e gráfica das palavras e das frases;

- segmentos básicos: os símbolos gráficos e as suas combinações intervindo nas associações básicas;

- leitura inicial: a leitura efectuada dentro do processo do ensinoaprendizagem.

- leitura corrente: a leitura para a qual aponta o processo do ensino (também pode ser chamada, com conotações particulares, leitura intelectual ou leitura expressiva); é uma leitura em que o contex to semântico, sob os seus diferentes aspectos- morfológico, sintáctico, lexical - permite resolver as singularidade prosódias e determinar em ligação com os símbolos gráficos de pontuação - os traços entonacionais das frases.

O tipo de código escrito determina o processo da leitura e determina parcialmente o processo do ensino da leitura. Assim, o ensino de uma língua que contém um subcódigo ideográfico requer necessariamente o emprego dum método em que associações serão directamente estabelecidas entre a face gráfica, a face semântica e a face fónica das palavras. Numa escrita parcialmente ou totalmente alfabética (ou silábica) põe-se o problema a saber:

i) se é preferível ensinar primeiramente o código escrito nas suas unidades e segmentos mínimos, concebendo a leitura inicial posteriormente como uma síntese 
realizada pelo próprio principiante, a partir das correspondências já adquiridas e integradas entre o plano gráfico e fónico da língua - método dito sintético.

ii) ou se é preferível ensinar primeiramente as associações directas e simultâneas entre as faces gráfica, fónica, semântica, partindo de uma amostra de palavras e de frases - método dito global.

Os métodos ditos sintéticos (ou silábicos) deveriam ser mais propriamente chamados de sintético-lineares, na medida em que tentam sintetizar as palavras numa só dimensão linear por adjunções progressivas de sílabas pertencendo a um tipo único. Os métodos ditos globais, que tentaram corrigir os vários defeitos dos métodos sintético-lineares, sem no entanto recorrer a uma análise muito mais aperfeiçoada do código escrito e do sistema fonológico, adoptam a segunda solução. Estes últimos estabelecem directamente associações entre as três faces (gráfica, fónica, semântica) das palavras e das frases. $\mathrm{Na}$ fase de estabelecimento das associações básicas, só considera as combinações de símbolos escritos representando unidades significativas (palavras e frases) já conhecidas - já ouvidas e compreendidas - pelo aprendiz numa fase preparatória. O conceito de leitura dentro do próprio método toma, portanto, um sentido diferente do sentido habitual: "a criança reconhece a frase escrita e pronuncia, não lendo-a, mas recordando-se da situação de produção em que foi enunciado”.

Delineiam-se assim as bases de um método global de ensino da leitura que tende a não isolar letras ou sílabas das palavras gráficas, nem a considerá-las fora do contexto da unidade portadora de sentido. João de Deus parte de estruturas significativas simples para outras que se vão complexificando, contendo as primeiras. Poderíamos mesmo sistematizar dizendo que em detrimento da soletração e do método silábico - que no início encontra a letra e o espírito vem a seguir -, no métodos global, primeiro encontra-se o sentido e a letra só aparece no fim. O rigor do método global assim preconizado por João de Deus encontrará, mais tarde, a sua confirmação na teoria psicológica de Gestalt (teoria da percepção, da forma), postulado dos sistemas mentais constituídos por totalidades organizadas, desde o início sob uma "forma" ou estrutura de conjunto, e nunca pela síntese ou associação de elementos dados no estado isolado antes da sua reunião. Essa percepção espontânea de um modo todo complexo favorece a fixação mnemónica.

Para fundamentar o seu método, João de Deus procede a um minucioso estudo da língua nos domínios fonológico e fonético. Na sua Cartilha Maternal reconhece a importância dos mestres lerem as palavras fazendo sentir às crianças o funcionamento articulatório dos seus órgãos do aparelho fonológico, preocupação essa revestida de grande modernidade. É uma atitude pedagógica susceptível de induzir a estimulação interna para a descoberta da língua falada, podendo mesmo contribuir para a correcção de perturbações elocutórias. 


\section{Aprendizagem do MÉTOdo: \\ PROCESSO GRADUAL DE COMPLEXIFICAÇÃO}

No ensino da leitura, o processo a seguir nunca poderá ser mecânico e surge da relação entre «método e verdade» (...) a partir do fácil para o difícil, do simples para o complexo, dando à criança, sucessivamente, as regras, levando-a até ao raciocínio e consciência do que faz quando lê.

M. da Glória Saraiva (2003, p. 142)

O processo de aprendizagem tem a sua génese na primeira percepção do mundo, na consciência da nossa integração e interacção com ele. Desta forma, inicia-se com os sentidos, que apontam para ver, ouvir, tocar e, a partir deste contacto imediato e sensível, o espírito, imbuído de uma natureza perspicaz e arguta, começa a conceptualizar e estabelecer as suas ordens e sentidos, integrados num contexto pragmático. Com a linguagem o refinamento cognitivo desenvolvese da mesma forma e o método João de Deus, em particular, não toma as figuras isoladas mas sempre integradas numa estrutura visual. Existem várias estruturas gráficas:

i) Combinações de figuras;

ii) Figuras ou grupos de figuras, em determinadas posições em relação aos limites da palavra gráfica;

iii) Combinações de figuras e de classes de figuras

iv) Divisão da palavra em sílabas gráficas - na fase da leitura inicial, primeira parte da Cartilha, o método João de Deus apresenta as palavras decompostas em sílabas gráficas e utiliza um artifício simples - sílabas alternadamente pretas e cinzentas - para obter esta decomposição sem quebra a unidade gráfica da palavra.

A Cartilha Maternal converte-se, assim, no cartão de visita deste modelo educativo, que promove o interesse e envolvimento na descoberta da leitura, tanto no sentido restrito da descodificação, como no sentido mais amplo da compreensão. Para além destes objectivos, radica ainda no modelo pedagógico João de Deus, um trabalho de desenvolvimento da criatividade, um esforço na desconstrução crítica, um espírito de iniciativa, numa interacção conjugada de todas estas vertentes. A leitura eficaz será aquela que é apresentada de forma agradável, conquistando a atenção da criança, numa interacção directa, objectivando o acto de ler.

A tradicional silabação gráfica - manifestada nas regras de mudança de linha e de colocação dos acentos gráficos - é facilmente preterida por não coincidir com uma silabação estabelecida em bases puramente fónicas. Assim se justifica 
que a divisão silábica, utilizada na Cartilha, contenha diferenças notáveis em relação à sílaba gráfica adicional, em função de critérios pragmáticos adaptados às necessidades da aprendizagem:

Ex:

Silabação tradicional: ter-ra; tos-se; só-ci-o

Cartilha: te-rra; to-sse; a-cção; só-cio

A emancipação deste método comparativamente aos tradicionais radica no acesso directo à leitura, de forma progressiva a partir de um inventário vocabular mais frequente e familiar. Este processo de aprendizagem alia, por isso, o contex to às singularidades individuais e idiossincráticas dos alunos. A apresentação do código escrito da língua sob a forma de listas de palavras, organizado e disposto por várias lições da Cartilha é um modo simples de analisar o código escrito destas línguas.

A dinâmica progressiva do método João de Deus permite reunir as vantagens de uma aproximação global e de uma abordagem sistemática do código escrito.

João de Deus privilegiava a palavra como instrumento importante na comunicação humana, elemento básico do discurso, cuja combinação das letras não se faz sem vogais e, assim sendo, "não fazia sentido aprender letras sem fazer essas combinações (...) a criança percepciona que a palavra usa-se para traduzir o que pensamos e o que sentimos" (M. da Glória Saraiva, 2003, p. 143).

$\mathrm{Na}$ linha da teoria piagetiana, o sincretismo da compreensão consiste exactamente no facto da compreensão do pormenor não se operar senão em função do esquema do todo e definido a partir dessa referência, fundamento utilizado nos métodos globais. A apreensão do significado faz-se a partir de uma estrutura macrotextual para se ir refinando em níveis mais profundos. A este nível, o método João de Deus é considerado uma sucessão de aplicações que correspondem à complexificação de códigos escritos num número crescente de figuras, cuja originalidade em relação ao métodos sintético-lineares é a de nunca considerar sílabas soltas nem interpretar figuras soltas fora do contexto de uma unidade portadora de sentido.

Revelando afinidades com os psico-linguistas piagetianos e na senda dos construtivistas, que advogam o carácter progressivo na elaboração das estruturas linguísticas, integradas e reflexivas das estruturas do conhecimento, João de Deus compreendeu a necessidade de uma ordem de gradação e hierarquização no ensino da leitura. O modo como investe na linguagem e pelo estatuto que lhe outorga, João de Deus demonstra-nos a importância do estímulo no processo evolutivo da aprendizagem, um impulso não apenas linguístico-cognitivo mas também sócio-afectivo. A justa dialéctica destas variáveis promove a maturação da criança, afinando-se com o tempo, o ritmo, o método e conteúdo. 
Pela conjugação e influência de todas estas variáveis, torna-se incorrecta e mistificadora a expectativa de obter performances similares de todas as crianças da mesma idade, diante dos mesmos modelos abstractos de ensino. Não há situação de real igualdade, defende o pedagogo. A moderna pedagogia, curiosamente em sintonia com os ideais dos pensadores como João de Deus, considera que os métodos devem reunir num mesmo programa propedêutico o ensino e educação, desenvolvimento ético e científico, a quantidade com a qualidade, a liberdade e a disciplina. Só a partir desta simbiose justa é que resultarão a proficiência e consagração real dos objectivos formativos, com toda a maleabilidade das estratégias pedagógicas. 


\section{BASES METODOLÓGICAS: \\ TENDÊNCIAS ACTUAIS DA PEDAGOGIA}

A metodologia João de Deus preconiza uma educação nacional com uma ligação muito directa com à sociedade onde se insere, mas não esquece que há um sentido mais universalista no nosso tempo facilitado pelos meios rápidos e mais directos de comunicação dos nossos dias. Não esquece também que as modernas tendências em pedagogia apontam para um ecletismo, que permite caldear os melhores métodos e processos, que se foram distinguindo através dos tempos. Aduz-se à metodologia do ensino da leitura, pelo método da Cartilha Maternal, uma panóplia de exercícios, lições, jogos e trabalhos para um desenvolvimento integral dos alunos. A observação directa das coisas apresentadas sobre a forma de surpresa promove uma estimulação sensorial e perceptiva (visão e audição) que se repercute nos exercícios de linguagem (dicção e vocabulário). Subjacente a este processo de ensino-aprendizagem desenvolvem-se trabalhos de expressão - desenho e exercícios gráficos - que irão consolidar a escrita. Inicialmente, nos Jardins-Escolas, a iniciação da escrita ocorria pelo processo da "Arte da Escrita", orientação feita através de cinco cadernos concebidos para o efeito, que tinha como objectivo regular o tamanho da letra, evitando-se mecanização na aprendizagem, fazendo ver a divisão do espaço, de linha a linha, em três partes iguais e sempre na senda "dos olhos guiarem os dedos, como àqueles os guia a inteligência" (apud M. da Glória Saraiva, 2003, p. 147).

A componente lúdica não é relegada no processo de ensino aprendizagem e deve ser uma actividade diária de forma a promover o equilíbrio no desenvolvimento. $\mathrm{Na}$ organização das actividades diárias, este tipo de trabalhos é realizado na parte da tarde e quanto aos materiais são vários, desde barro, a plasticina, fitas, papel de lustro, tintas. Dependendo do estágio de desenvolvimento da criança assim se podem fazer desenhos à vista, dobragens, entrelaçados. No que concerne aos objectivos destes trabalhos, está comprovado o desenvolvimento da motricidade fina das crianças e da memória visual, aduzindo-se ainda o facto de ser um espaço de expressão livre e criativa, tendo subjacente um sentido estético. $\mathrm{O}$ modus operandi exige concentração, entrega, criatividade e é sempre um produto dos sentimentos e emoções, também eles uma forma de concretização dos temas da vida. 


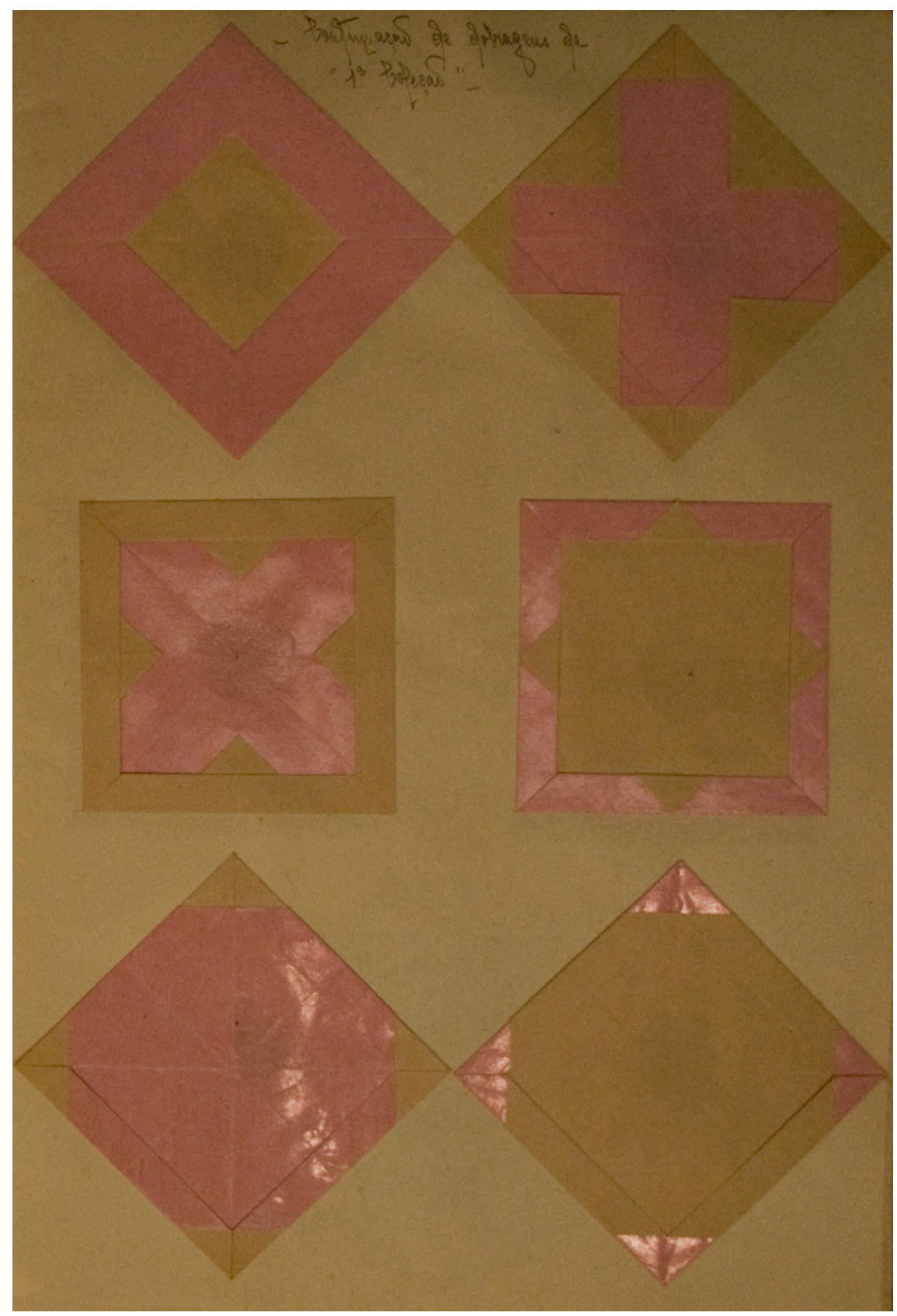

Fig. 39: Exercício escolar com colagens. 

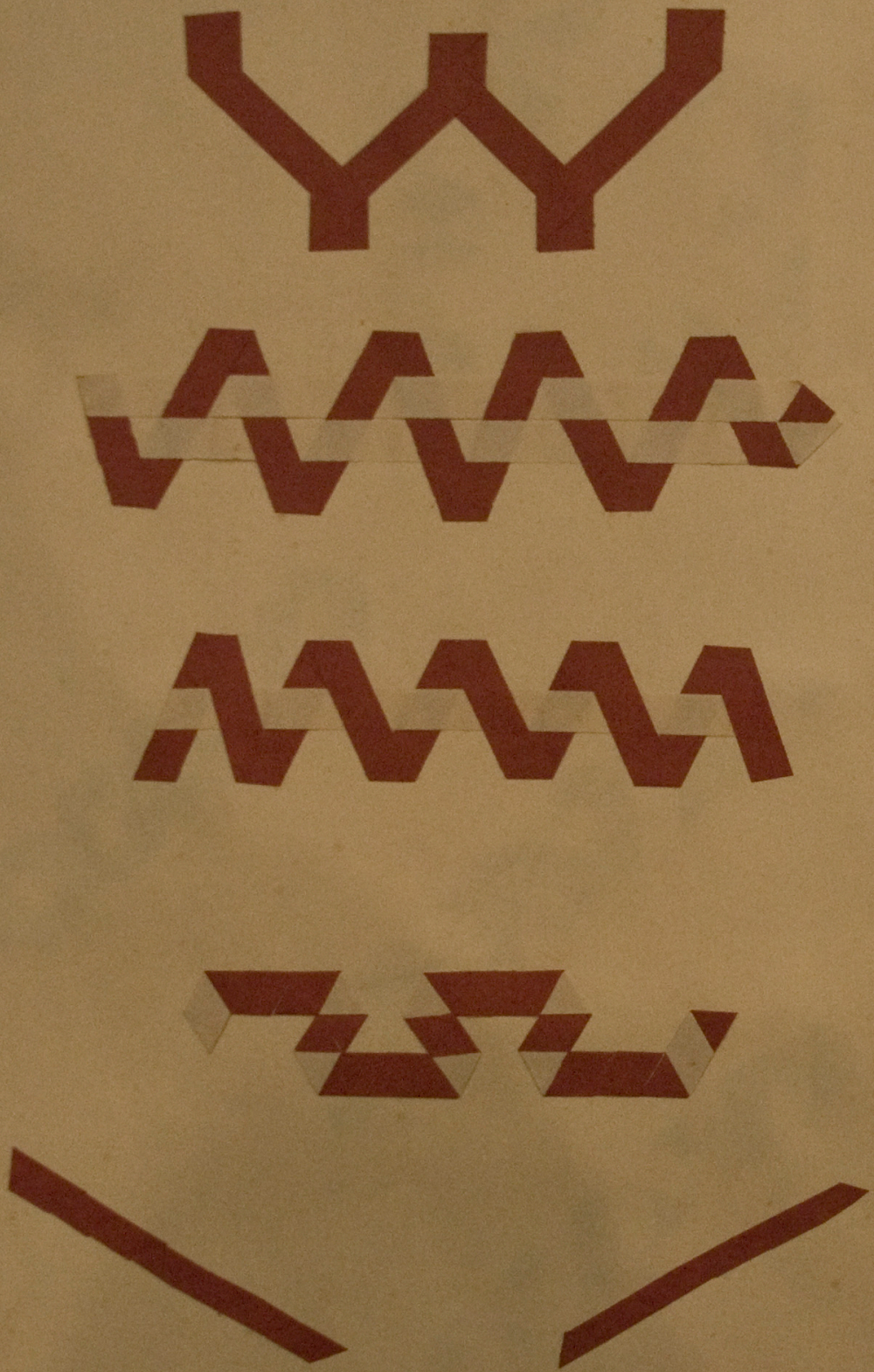


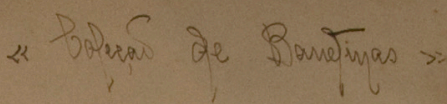
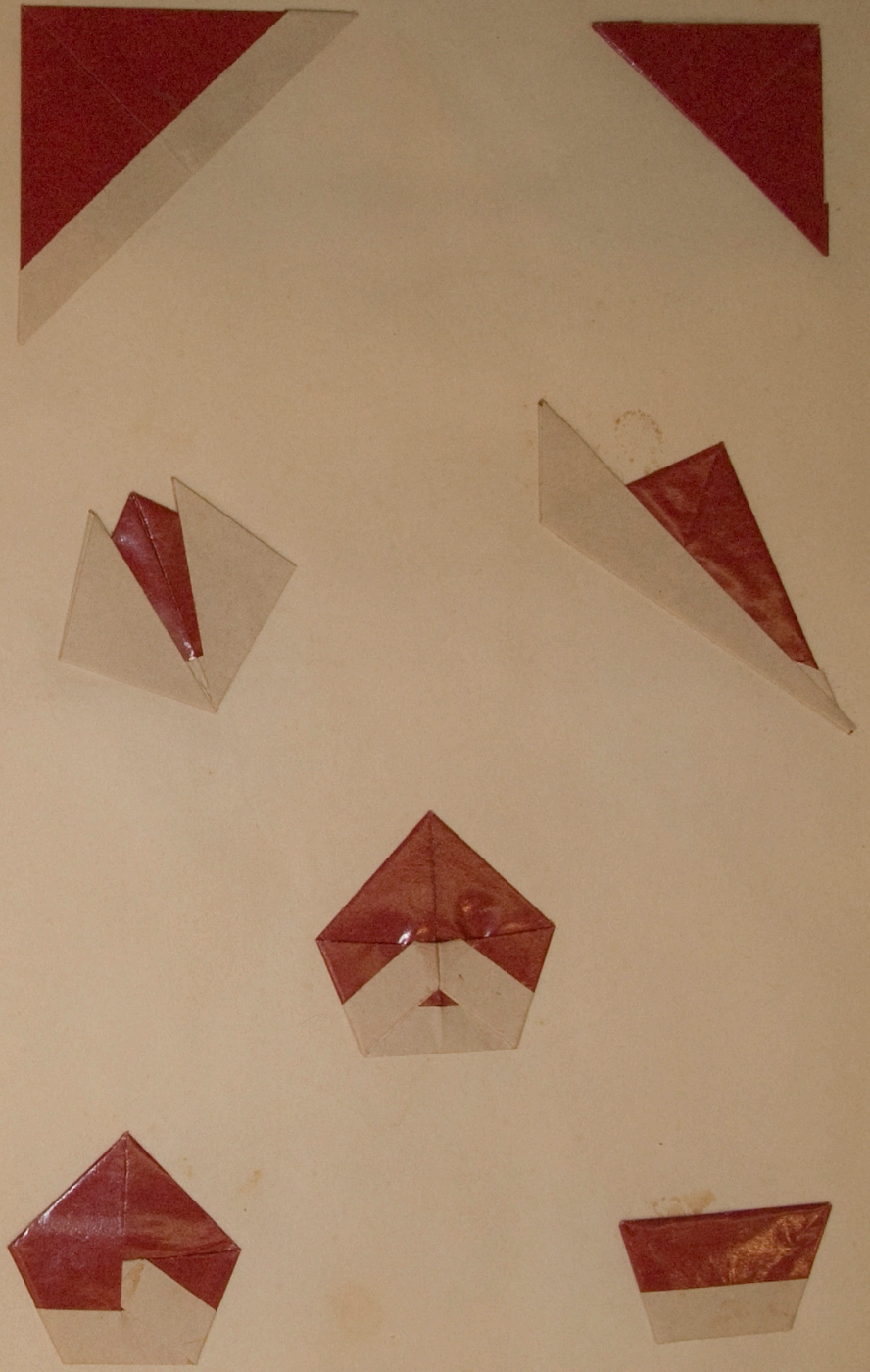

Fig. 41: Exercício escolar, "Colecção de barretinas”. 


\section{INICIAÇÃO À MATEMÁTICA: MATERIAIS DIDÁCTICOS E FUNDAMENTAÇÃO}

No que respeita à iniciação da matemática, João de Deus Ramos dava primazia às construções fröebelianas; contudo a multiplicidade de matérias servia-se das lições de coisas e através de situações quotidianas. "Maria da Luz considerava esta iniciação muito importante, referia que os exercícios de cálculo mental desenvolvem importantes faculdades cerebrais (...) neste sentido Maria da Luz aconselha o uso de materiais como: Cuisinaire, Blocos Lógicos, Calculadores, Ábaco, material constituído por unidades para contagem como palhinhas e bastões». As iniciações matemáticas, bem como toda e qualquer aprendizagem, estão associadas à vida prática da criança, utilizando exemplos que lhe sejam familiares, rentabilizando experiências e virtualidades.” (M. da Glória Saraiva, 2003, p. 148).

Todos estes objectos instigavam directa e indirectamente várias potencialidades da criança: a noção da cor, o exercício da memória, o desenvolvimento do vocabulário, a noção de unidade e pluralidade, a relação com o espaço, a percepção do concreto e abstracto, capacidades de desconstrução e reconstrução, inclusão e interacção, seriação e classificação.

As técnicas utilizadas até hoje na Educação Infantil devem muito a Fröebel pois para ele as brincadeiras e os jogos são o primeiro recurso no caminho rumo à aprendizagem, permitindo o treino de habilidades que as crianças já possuem e o surgimento de outras. As crianças começavam formando círculos, movendo-se e cantando, pois assim atingiriam a noção de unidade e de conjunto, o material escolar viria promover oportunidades de forma a tirar proveito educativo da actividade. As correntes construtivistas, estruturalistas, interaccionistas e cognitivistas, que se principiam com Piaget, consideravam o aluno como um ser capaz de construir o seu conhecimento. Maria Filomena Caldeira (2009, p. 25), na sua teorização sobre a aprendizagem lúdica da matemática, refere várias metodologias e pressupostos teóricos e enumera concepções interessantes quanto às funções dos referidos materiais na prática educativa: função informadora (a criança na observação e manipulação do objecto determina as suas qualidades como a cor, tamanho, textura...), função estruturadora (a sua construção e proximidade pode despertar, aguçar capacidades sensório-motoras, perceptivas e operativas), função modeladora (estrutura a construção da sua personalidade), função mediadora (o material pode ser mediador entre o concreto e a ideia e o caminho que leva a criança da acção ao pensamento), função representativa (didáctica instrumental), função instrutiva. 


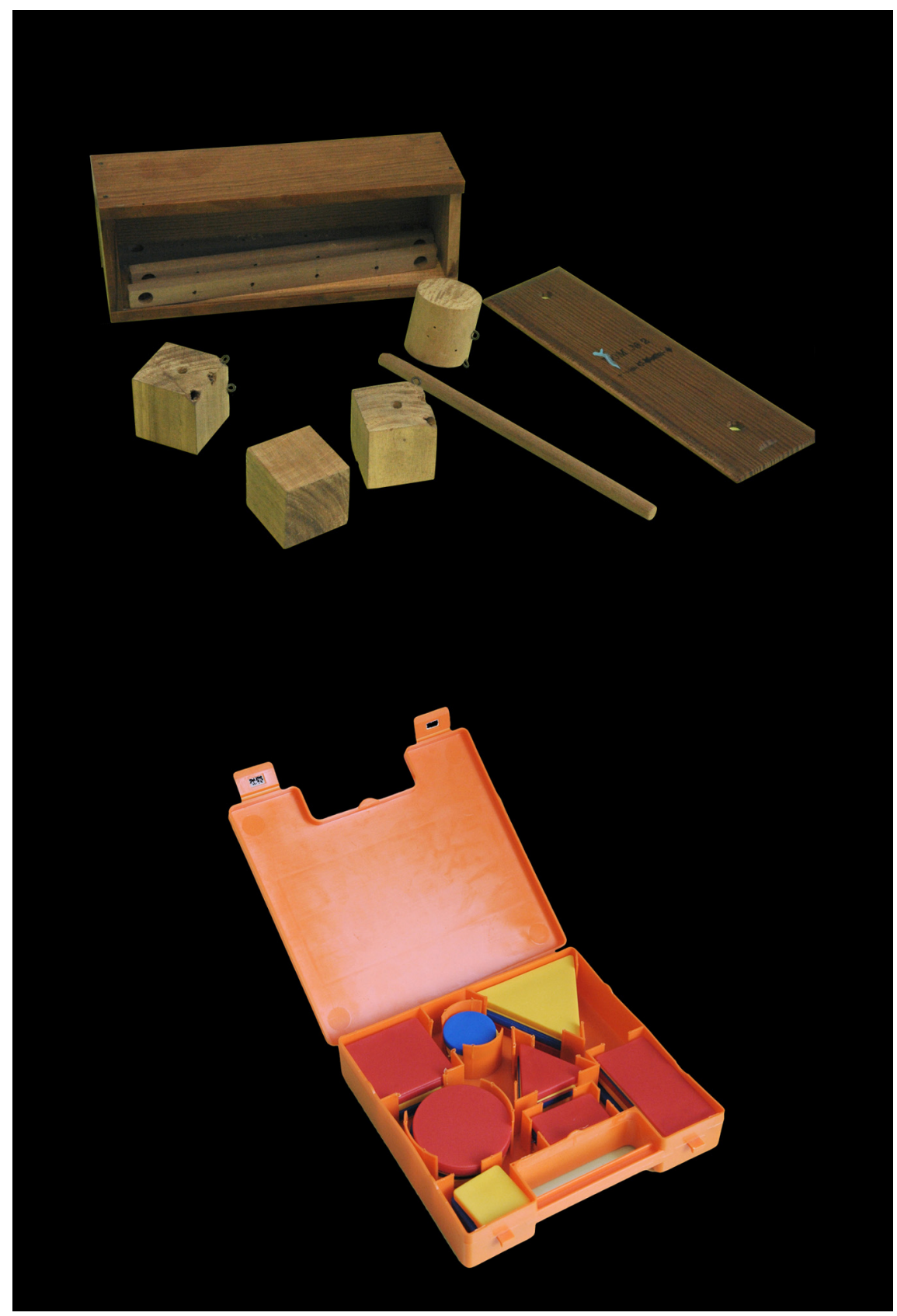

Figs. 42-43: Dom de Froëbel; Blocos lógicos. 

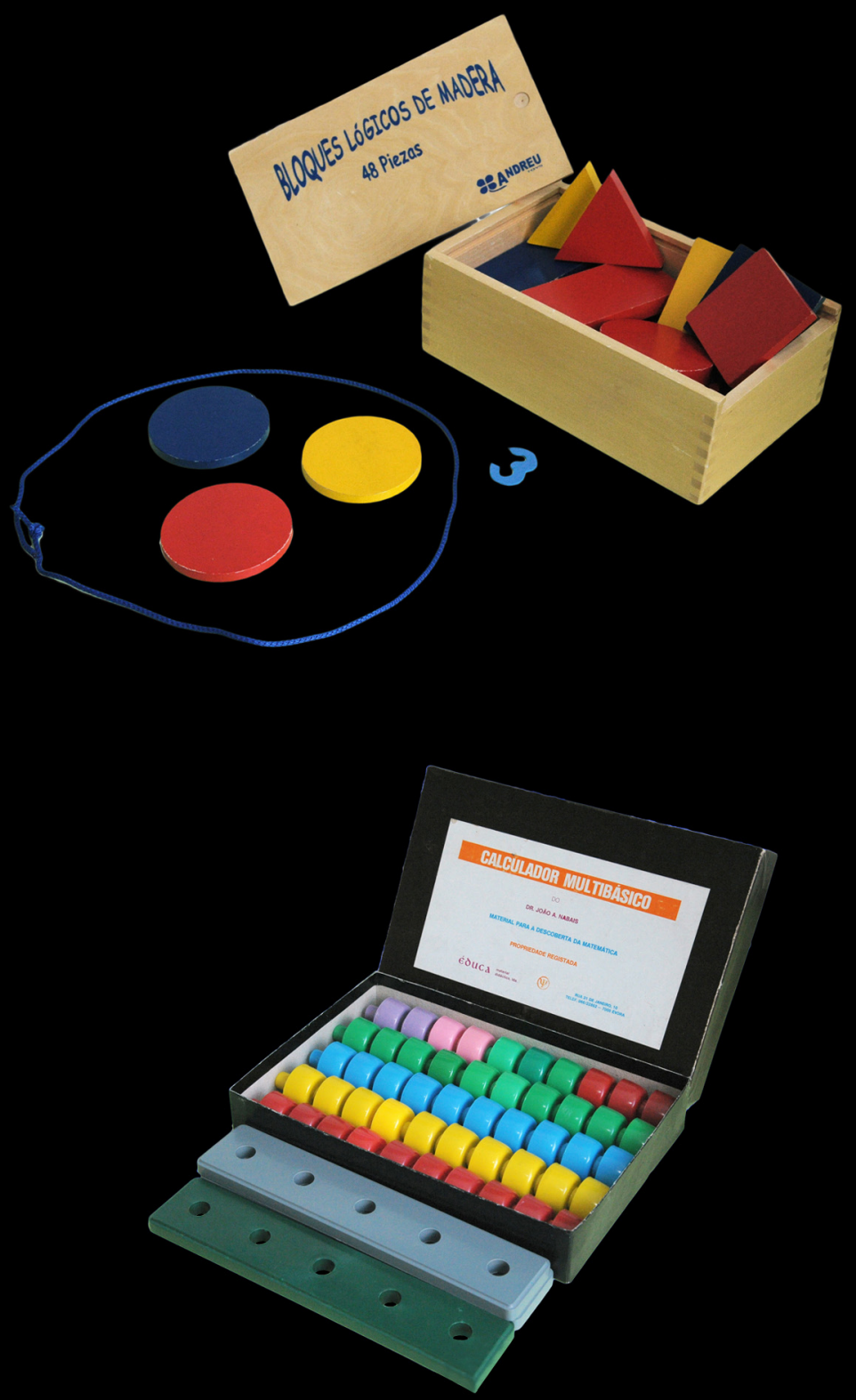


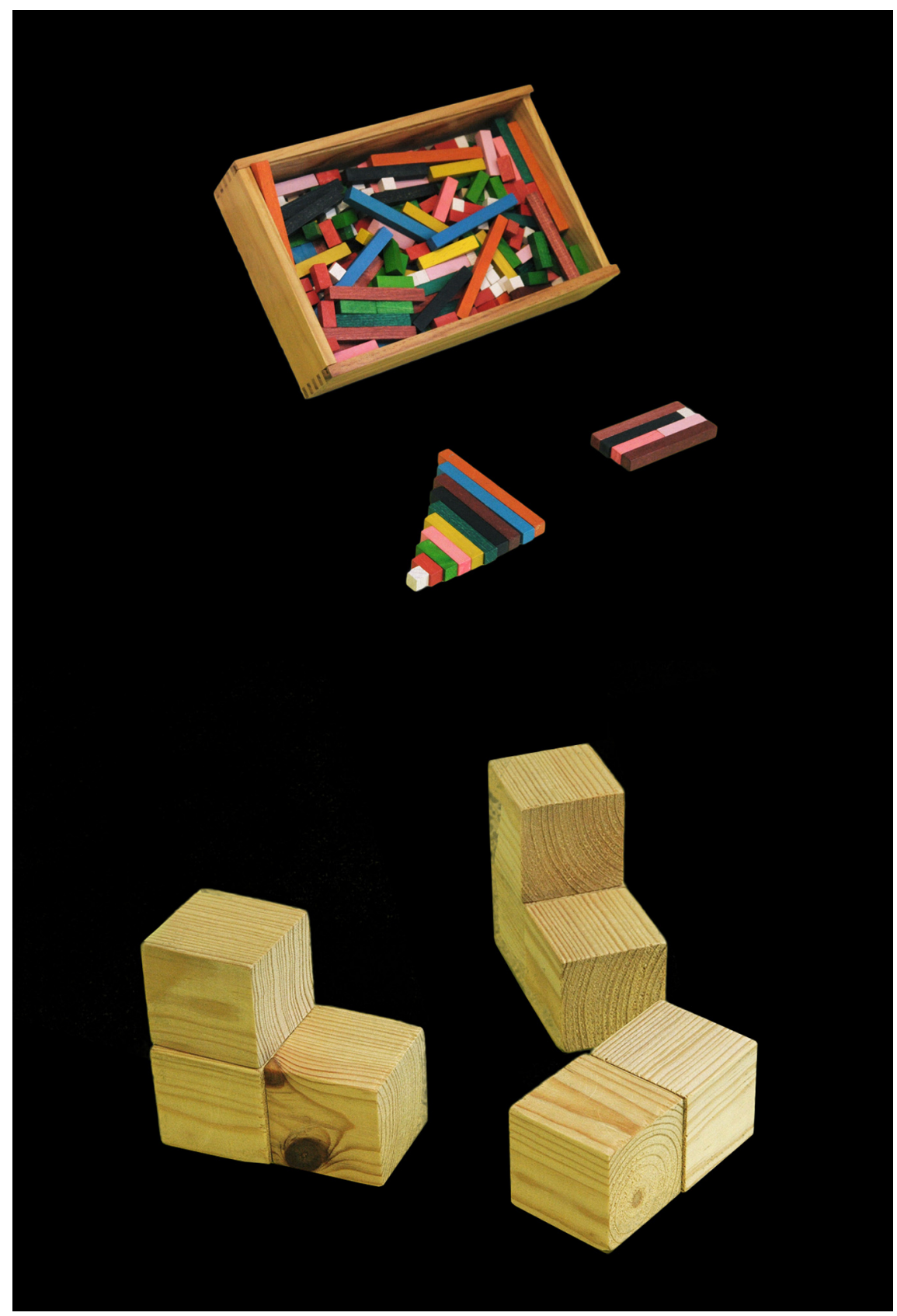

Figs. 46-47: Cuisinaire; Dom de Froëbel. 

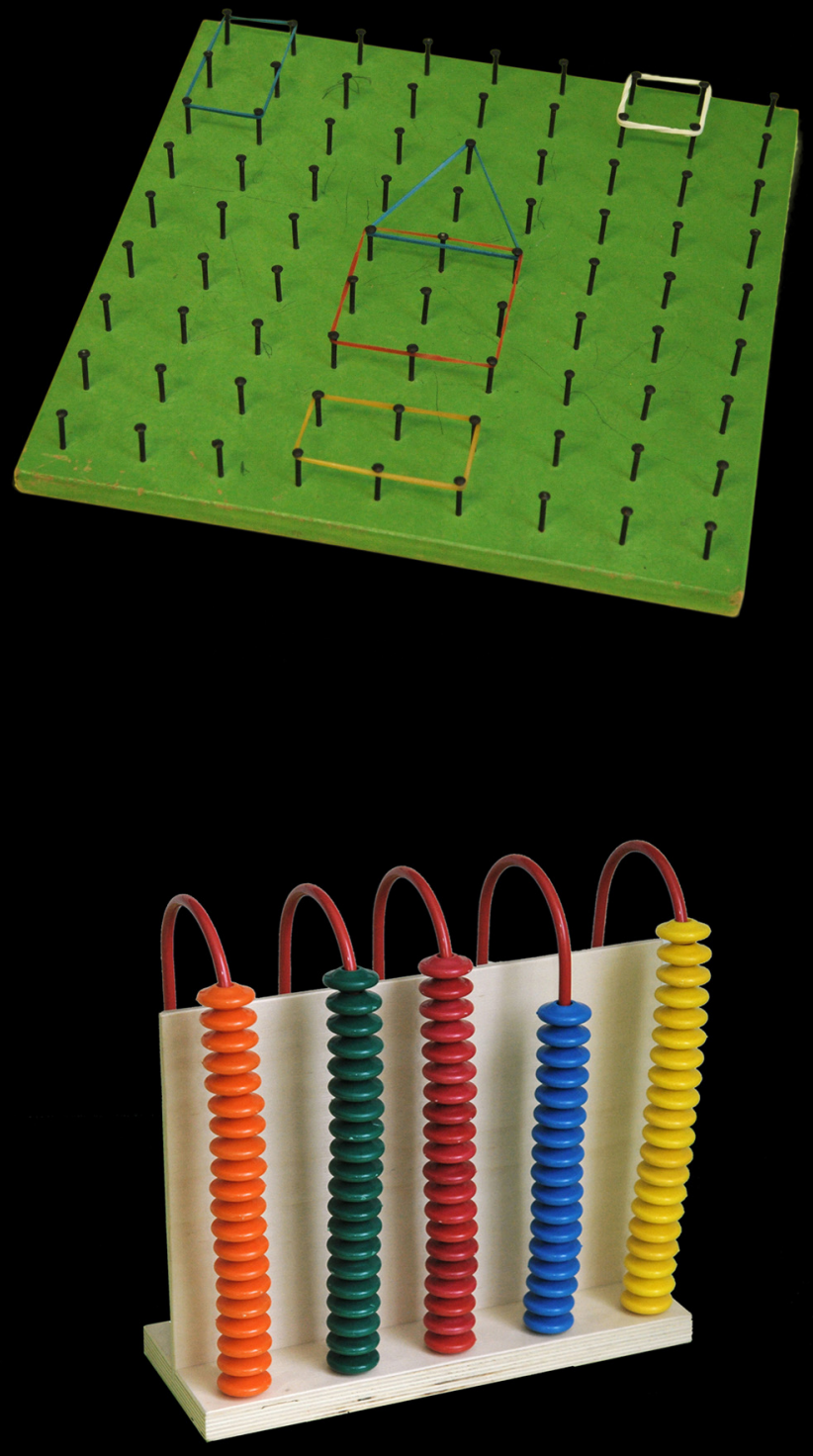


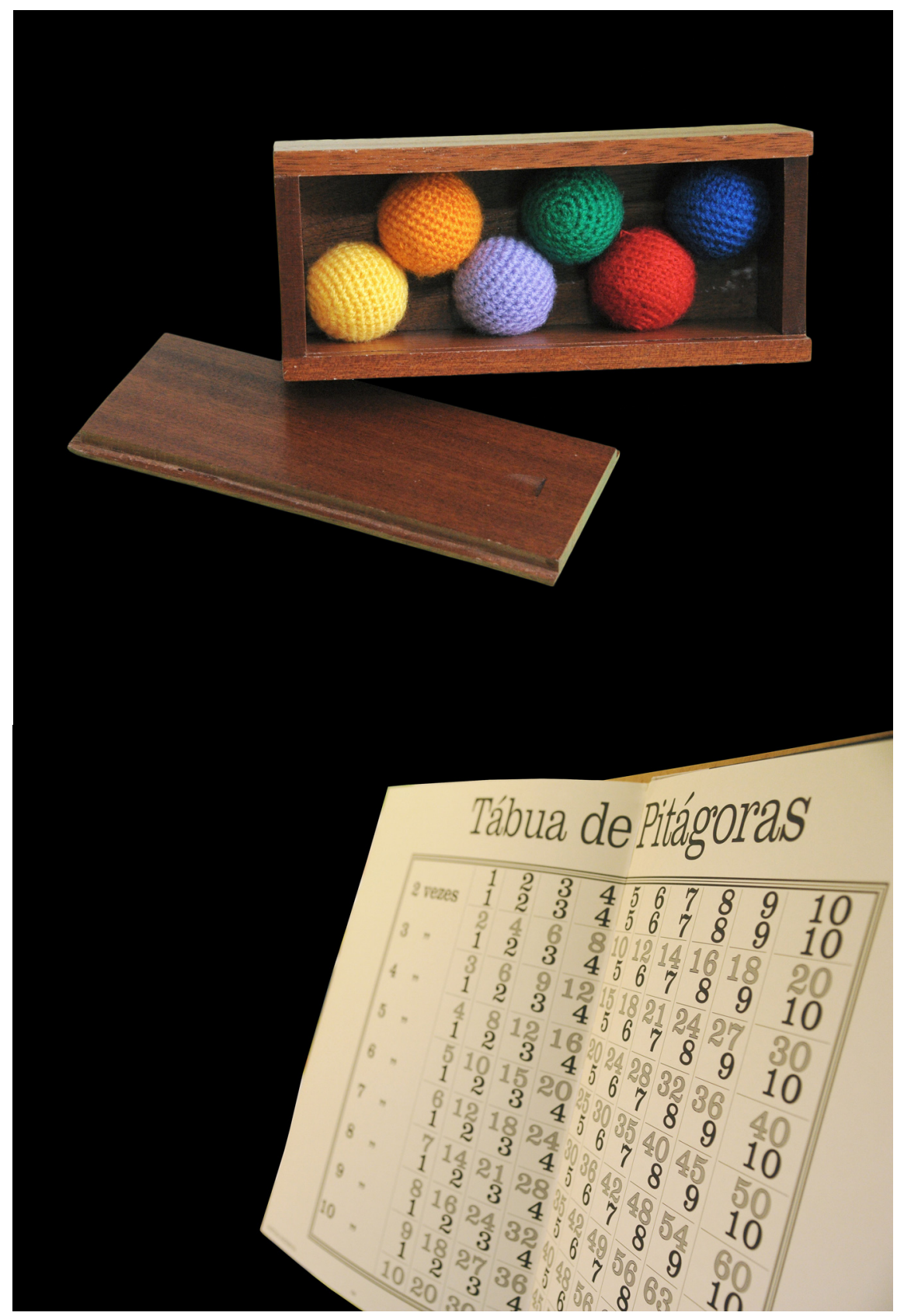

Figs. 50-51: Dom de Froëbel; Tábua de Pitágoras para o ensino da matemática. 


\section{Método João de Deus, UMA PEDAGOGIA ACTUALIZADA}

João de Deus, não para copiar mas para ter um termo de comparação, visitou escolas infantis e maternais em França e na Suíça. Seguindo-lhe o exemplo, os seus continuadores mantêm-se em ligação constante com centros educativos garantindo um actualizado nível pedagógico aos Jardins-Escolas João de Deus. (...) Com intenção pedagógica é estudada uma arquitectura funcional e tanto quanto possível com características nacionais e até regionais. Decoração, música, arte, tradições, tudo tende a identificar a criança com o seu património nacional. (...) Como princípio muito importante temos a exclusão de prémios e de castigos, de prémios que quase sempre, injustamente, compensam situações favorecidas pelo destino e cultivam vaidades fúteis (...) Estimula-se também assim a necessidade de expressão e comunicação. O desenvolvimento verbal é objecto de um cuidadoso programa. Diálogos, fantoches, recitação, teatralização, pequenas narrativas e histórias, exploração de frases que conduzirão ao texto livre, são alguns dos processos utilizados (...). A observação de gravuras de diversos tamanhos apresentadas em sequências, o reconhecimento de objectos e o seu nome correctamente e apropriadamente usados, constituem uma importante propedêutica para a leitura; assim como os jogos e situações que permitam uma boa lateralização. Um dos aspectos mais originais do método é a apresentação dos Temas da Vida de uma forma cíclica e relacionada que permite dar à criança o conhecimento de si própria, do que a cerca e situa-la no tempo e no espaço. Aproveita-se assim um método associativo que facilita a aquisição de noções através da relacionação que exercita o raciocínio. Nada se faz por acaso. 


\section{Lições das CoIsas/Temas da VIDA}

Conforme M. da Glória Saraiva (2003, p. 151) destaca: “é neste sentido que João de Deus Ramos organiza 'os ciclos de conhecimentos' que se querem sucessivos e interdependentes, tendo por base um plano geral em forma de espiral; procura abordar-se o homem como indivíduo e depois como pertencente ao corpo social. Esta metodologia destina-se a contribuir de forma eficiente para a integração da criança no meio, começando a conhecer-se a si própria e ao ambiente através de diálogos onde no caminho da descoberta e enriquecimento do vocabulário familiar. (...) O vocabulário vai se integrando pelo somatório das lições de coisas com que as crianças estão constantemente em contacto. Os nomes das coisas aprendem-se conhecendo coisas, o corpo docente induz delicadamente a criança a observar, a perscrutar, a executar as operações psíquicas fundamentais de análise e síntese. Encontramos referências a estas lições de coisas/temas de vida, desde a criação do $1^{\circ}$ Jardim-Escola." 

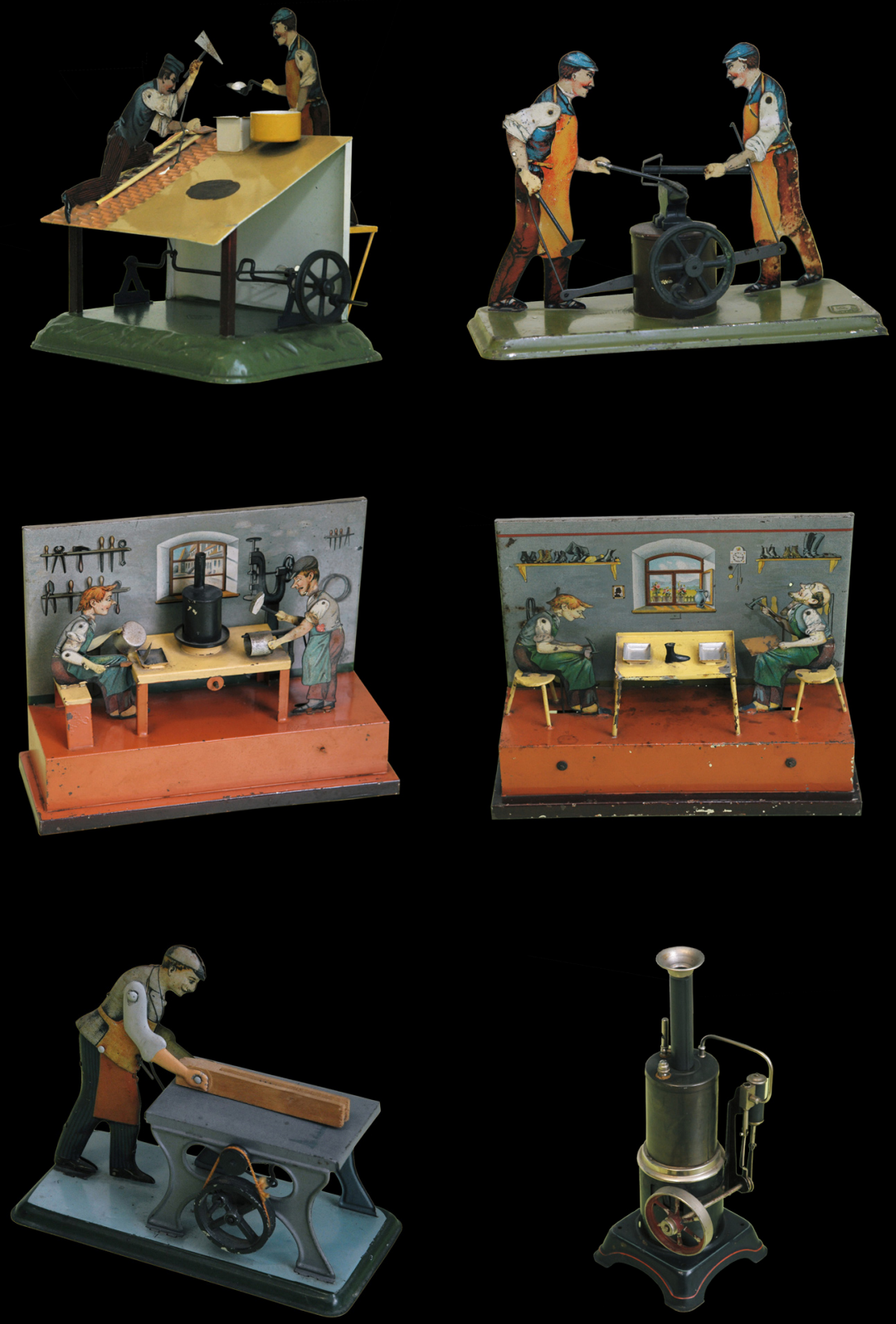

Figs. 52-57: Dois pedreiros; Dois ferreiros a trabalhar na bigorna; Dois latoeiros; Dois sapateiros; Latoeiro, artesão que produz artefactos produzidos em metal; Ferreiro a limiar o ferro; Caldeira de vapor.. 


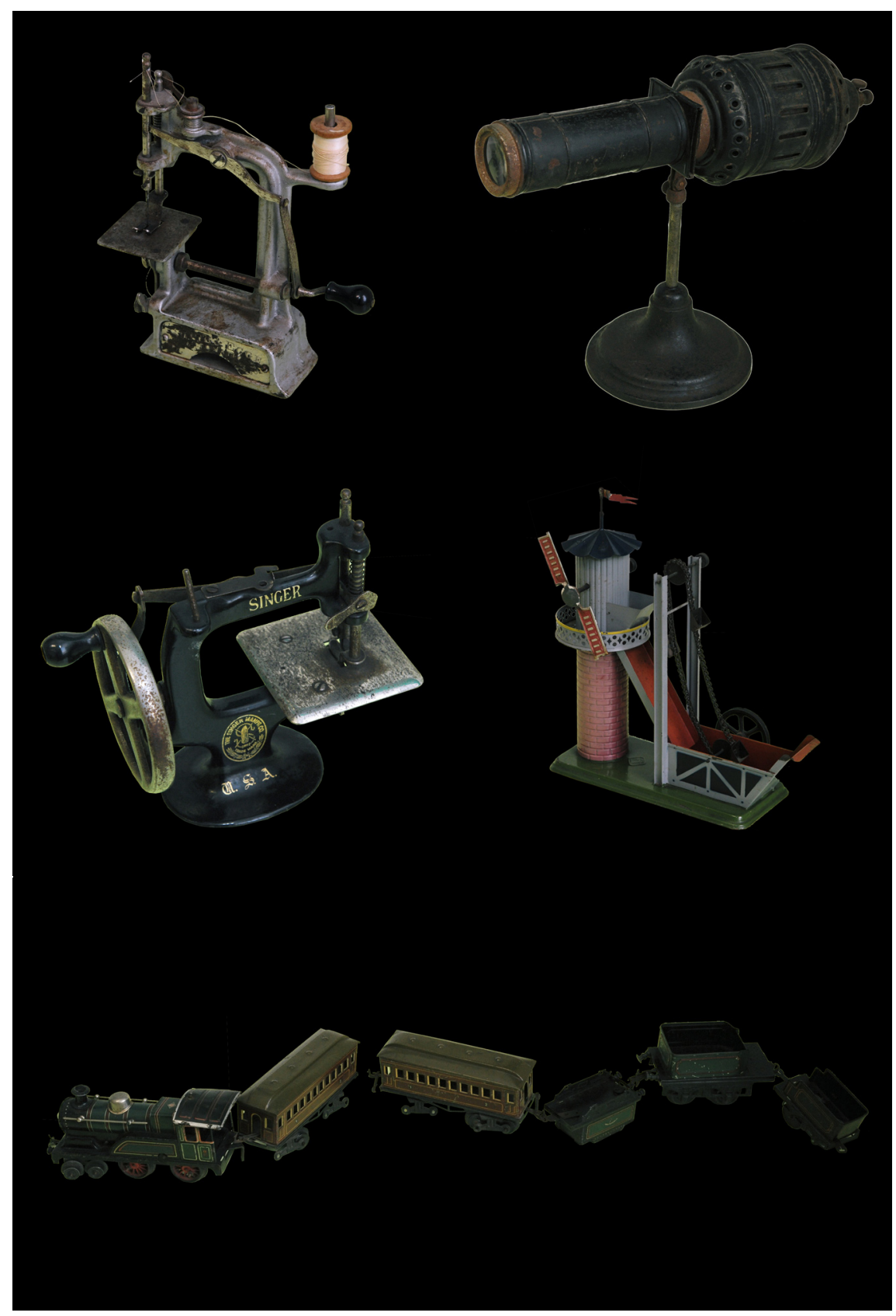

Figs. 58-62: Máquina de Costura Smith \& Egge automatic; Um projector de slides; Máquina de costura Singer; Moinho alto com guindaste com pás metálicas; Comboio - composição 


\section{A ESPECIFICIDAdE PEDAGÓgICA DE CADA GRUPo ETÁRIO: UM QUADRO DOS VÁRIOS ESTÁGIOS DE DESENVOLVIMENTO}

3-4 anos: o menino tem predominância de actividades livres e criativas com apelos progressivos a uma integração em grupo, terá à sua disposição jogos sensoriais, fará alguns exercícios motores, rodas e canções e será estimulado para exprimir e comunicar.

5 anos: uma idade muito importante. É a fase pré-primária, fase de transição lhe chamam alguns países, pois representa uma plataforma para toda a sua escolaridade futura. (...) A iniciação à matemática e ao cálculo, noções físicas de distância, situações relativas, estudos de formas (...). Usam-se materiais variados que permitam objectivar o raciocínio matemático pois a capacidade de abstracção só amadurecerá mais tarde. Noções de matemática moderna e de matemática tradicional e vivida são apresentadas de forma simples e clara, sem menosprezar a capacidade real da criança.

Desta forma, a organização do contexto educativo é feita por grupos de crianças com formação horizontal, por níveis etários e com um programa específico e ajustado a cada nível, sempre num clima de interacções equilibradas onde se privilegia a prática activa de disciplina. 


\title{
O PROCESSO DE APRENDIZAGEM A PARTIR DO SENTIDO LÚDICO
}

\author{
Brincar é a fase mais importante da infância e do desenvolvimento \\ humano neste período - por ser a auto-activa representação do interno - a \\ representação de necessidades e impulsos internos.
}

(M. Filomena Caldeira, 2009, p. 38)

"A palavra brinquedo deriva do verbo brincar; e a função de brincar só tem sido motivo de observação cuidada para os industriais de quinquilharias, a quem, sob o exclusivo aspecto de negócio, interessa deveras saber o que mais agrada à curiosidade buliçosa dos seus prováveis e pequeninos clientes. Os pais e os educadores, esses, relegam à margem o assunto, porque nunca quiseram apreciá-lo entre os subtis quesitos da psico-fisiologia infantil. Brincar parece um fenómeno natural e irreprimível da actividade da criança, que não pode deixar de ser o que é. Eis o engano. Senão, vejamos: o que vulgarmente se chama uma brincadeira, resultante do irrequietismo alvoroçado, impetuoso, saltitante da gente alegre e moça, sem outro objectivo, para os sentidos, que não seja o que proporciona o acaso, servirá, de facto, para dar plena felicidade à infância? Não haverá motivo para supor que o malefício de brincar é como o daquelas flores, de perfume activo, que no aconchego da casa nos dão prazer, mas envenenam o ar que se respira? A realidade visível, incontestável, é que nenhuma criança, com saúde, pode estar quieta. Exige-o o seu crescimento físico e também a natural inquietação dos sentidos que tudo buscam ver e palpar. A criança, dispondo de si livremente, tenta vencer obstáculos, fazer equilíbrios, exercitar forças, e é aí que realiza uma ginástica instintiva; mas também procura, simultaneamente, tomar em suas mãos o quer que seja que desperte curiosidade e possa ter, de improviso, destino imaginativo. Se, todavia, atentarmos nas suas atitudes, reconheceremos que ela não está inteiramente satisfeita, nem com o que tem, nem com o que faz, pois é levada, por impulso incontido, a destruir o que tem nas mãos, para ver "Como é feito; e revolve e baralha tudo, com alvoroço, porque é condição intrínseca da sua existência querer saber. Esta é a realidade que, sob os mais variados aspectos, ninguém há que não tenha tido ocasião de observar. E a estupefacção duma criança numa loja de brinquedos?! Que haverá ali, naquela multiplicidade de bugigangas, na sua maioria, imperfeitíssimas e de mau gosto, que explique o pasmo e o entusiasmo infantil?"

Bolas, bonecas, miniaturas de automóveis, de comboios, de barcos, de aviões, de bichos diversos, de carro de bois e de cavalos, o cavalo com selim, o burro com respectivas cangalhas, o pau e o arquinho para saltar e correr, o palhaço com seus esgares, jogos de improvisação e de paciência, a interessante construção do 
«mecano», em peças soltas; e a par de tudo isto, a espingarda e a espada, à militar, e os soldados de chumbo, de mistura com os motores de ar quente e de vapor, etc. Se procurarmos a ideia-mater de todos estes artefactos e quinquilharias sem ainda fazer reparo nas preferências dos dois sexos, verificamos que tudo aquilo é uma estropiada redução dos objectos de uso doméstico e de utilidade corrente, merecendo-nos destaque (à parte o preço) as maquinetas de aplicação profissional ou científica. E depois, verificamos também que o rapaz prefere a bola, o avião, barco, o comboio, o carro de bois, a espingarda e a espada ou o mecano; e a menina, a boneca, o ferro de engomar, os apetrechos de cozinha, a mobília de sala, a pequena máquina de costura, ou, talvez, os jogos de paciência. Ora, não estará aqui já uma síntese abreviada, para se tirar uma conclusão? As crianças dão preferência, em geral, às coisas que melhor se coadunam com as suas tendências inatas e estas revelam, em última análise, que a infância o que mais procura é preparar-se para a vida. A gente miúda quer ser como a gente grande, quer pensar e resolver por si, fazendo as coisas livremente, tal qual como as pessoas adultas.

$\mathrm{O}$ caso da menina que gosta mais da boneca, feita por ela, duma rodilha de trapos, do que da fabricada e adquirida por compra, é vulgarismo e bem expressivo. O cavaleiro de cavalo de pau (ou de cana) montado em atitude altiva, segurando as rédeas que não passam duma guita, e dando a impressão de caminhar a galope, lança ao desprezo o cavalo de papelão, ainda o de maior tamanho, comprado na lojas, por não proporcionar o mesmo encanto, apagadas as primeiras impressões. E com razão. Não serve para andar, senão por meio de rodas; mantém-se estático, imóvel, sem expressão de vida; e a criança passa a tratá-lo corno a um corpo morto: resolve autopsiá-lo, rompendo-lha a barriga, para ver como é por dentro. Isto prova que o brinquedo fabricado, em série e adquirido nas lojas, não tem o préstimo que pode supor-se: ilude quem o recebe e também quem o dá. Mas poderá substituir-se? E com vantagem? Sem dúvida. As variadíssimas modalidades educativas que se encontram sistematizadas nos Jardins-Escolas João de Deus, cativam e estimulam a actividade dos sentidos nas crianças, desenvolvendo regular e progressivamente as suas faculdades. Aponto o exemplo. Apenas para me firmar em factos. Sobretudo, a modelação em barro e os trabalhos manuais, desde os entrelaçamentos e dobragens em 'papel de cores, para o início do bom gosto, até à realização de pequeninos artefactos, em arremedo de carpintaria, de mercenaria, de mecânica, de física e de química, interessam muito mais, porque avivam o espírito inventivo e dão maior prazer. Por sua vez, os jogos de movimento livre, ou em recinto apropriado, constituem, já de si, a coordenação de actividades, com submissão a regras e a condições correspondendo aliás, à manifesta preferência da criança pelo jogo. Deverão incluir-se tais ocupações infantis na designação genérica de «brincadeira»? 
Não. Decerto. O significado corrente da palavra «brincar» subentende que a actividade da criança, se exerce por acaso, ao impulso de ocasião, sem limites, nem objectivo previsto. Dentro de boa lógica, isto abrange a condenação formal de todos os artifícios no ensino, portanto, da expressão vulgarizada aprender, brincando. Aprender é uma coisa séria; e, como diz o povo, «com coisas sérias não se brinca».

João de Deus Ramos (1943). 
Em suma, neste olhar que lançámos sobre os fundamentos e pressupostos teóricos do edificio propedêutico de João de Deus, identificamos uma importante actuação pedagógica, com todos os seus méritos performativos e humanísticos. O ideário de educar e formar teceram a quatro mãos um programa que visa não só a integralidade de conhecimentos do homem como a sua preparação humana, ética e moral que se repercutirá num desempenho activo e interventivo na sociedade. A. Maria Mira (1995, pp. 22-3) acrescenta, "enquanto não se perspectivar a educação como o alicerce indispensável para a construção de uma sociedade harmoniosa e desenvolvida; enquanto não se entender que a escola, mais do que transmissora de saberes, quantas vezes inúteis pois desinseridos da vida real, deve ser formadora e preparar todas as crianças, qualquer que seja a sua origem, à autonomia e à participação social, e não à dependência submissa e conforme. É na escola que a criança forma a sua primeira imagem como ser social, imagem essa que irá condicionar, positiva ou negativamente, todo o seu desenvolvimento ulterior como adulto. E deixo aqui um desafio e uma interrogação: «ser fiel aos grandes espíritos e continuar a impulsão criadora, renovadora, transformadora» (...) para além das homenagens justamente prestadas a João de Deus por ocasião dos aniversários do seu nascimento e morte, porque não proceder à actualização da sua Cartilha Maternal e à aplicação experimental do seu método que, mais do que qualquer outro, pelas suas características, parece convir a todas as crianças, qualquer que seja a sua origem social? Que maior homenagem se lhe poderiamos prestar?" 


\section{Parte III}

$1^{\circ}$ Jardim-Escola JoÃo de Deus:

\section{Projecto Sempre inacabado}





\section{Jardim-Escola Jõ̃o de Deus. \\ Projecto inacabado}

O filho do poeta João de Deus falecerá a 15 de Novembro de 1953. O seu legado é incontornável: entre 1911 e 1953 ergueu 11 Jardins-Escolas, o Bairro Escolar do Estoril (1928), os Cursos de Didáctica Pré-Primária João de Deus (1943), o Museu João de Deus - Bibliográfico, Pedagógico e Artístico (1917). Viria a suceder-lhe Maria da Luz de Deus Ramos, sua filha, que estaria à frente dos destinos da Associação dos Jardins-Escolas João de Deus durante quase meio século. 


\title{
Maria da Luz de Deus Ramos
}

\author{
Há que fazer uma distinção bem nítida entre Educar e Ensinar: \\ a primeira preocupação deve ser a Educar, \\ e formar moral e espiritual do indivíduo \\ e só depois virá a de Ensinar.
}

Maria da Luz de Deus Ramos (1982, p. 5)

Neta do poeta João de Deus e filha de João de Deus Ramos, dedicou a sua vida ao programa pedagógico idealizado pelo avô e concretizado pelo pai e à educação infantil em geral. No domínio académico, detém o grau de bacharel dos cursos de preparação de Professores adjuntos ( $8^{\circ}$ e $11^{\circ}$ grupos) do Ensino Técnico e Profissional e o curso de Ciências Pedagógicas, ambos na Faculdade de Letras da Universidade de Lisboa.

A partir de 1943, passa a exercer actividades educativas nos Jardins-Escolas, no Curso Superior de Infância pelo Método João de Deus. Após a morte de seu pai (1953), assume a presidência da direcção da Associação dos Jardins-Escolas João de Deus, promovendo a sua expansão e consolidação. De entre muitos dos seus méritos enumeram-se ainda a autoria e ilustração de muitos contos infantis, a redacção e adaptação de peças de teatro, numa vocação permanente para o ensino e pedagogia.

O seu nome aparece intrinsecamente ligado a muitas iniciativas, não só em relação ao legado dos Jardins-Escolas mas também no redireccionamento da acção educativa e na actualização do método de ensino. Maria da Luz colocou a sua imagem credível e a sua autoridade pedagógica ao serviço da divulgação, junto de um público alargado, de perspectivas inovadoras como a literatura para a infância, a juventude, a assistência e protecção de menores e a sensibilização artística. Todos estes esforços de alargamento do pensamento do seu tempo foram redimensionando uma escola activa e reforçando a defesa da disciplina e do método. Além disso, a sua superior capacidade de gestão ficou bem patente na persistente e iluminada forma como conduziu os destinos da associação durante a conturbada década de setenta, já referida oportunamente (cf. pp. 30-31).

Além de vários pareceres e opiniões para vários jornais de referência, a pedagoga publica ainda as seguintes obras: Cadernos de Educação da Infầncia, $A$ Criança Portuguesa, Jornal - Magazine da Mulher, Mocidade Portuguesa feminina, Noesis. Maria da Luz desenvolve a teoria do desenho infantil à luz dos modernos princípios pedagógicos, entendendo o desenho não apenas como um exercício gráfico, mas como uma linguagem humana que, à semelhança da palavra, é outro sistema semiótico e que contribui para o desenvolvimento da criança e para a exteriorização da sua sensibilidade. Foi meritoriamente reconhecida em diversas 
homenagens: Grau de Comendador da Ordem de Instrução Pública (Março, 1985); Grande-oficial da Ordem de Instrução Pública (1990); "Prémio especial pelo serviço prestado e dedicação no seu trabalho com crianças" atribuído pela Organização Mundial de Educação Pré-Escolar (Julho de 2000); a Escola Básica/ JI do I ${ }^{\circ}$ ciclo $n^{\circ} 185$ da Charneca (Lisboa) passou a designar-se Escola Básica do $1^{\circ}$ ciclo Maria da Luz de Deus Ramos por Despacho de Sua Excelência o Secretário de Estado da Educação (Abril de 2004); atribuição do seu nome à rua onde está situado o Jardim-Escola João de Deus em Santarém (Junho, 2004).

A sua vida estará ligada à obra de João de Deus pela capacidade que teve de fundir ao projecto e ao ideário de seus antecessores uma modernidade e actualidade pedagógicas. 


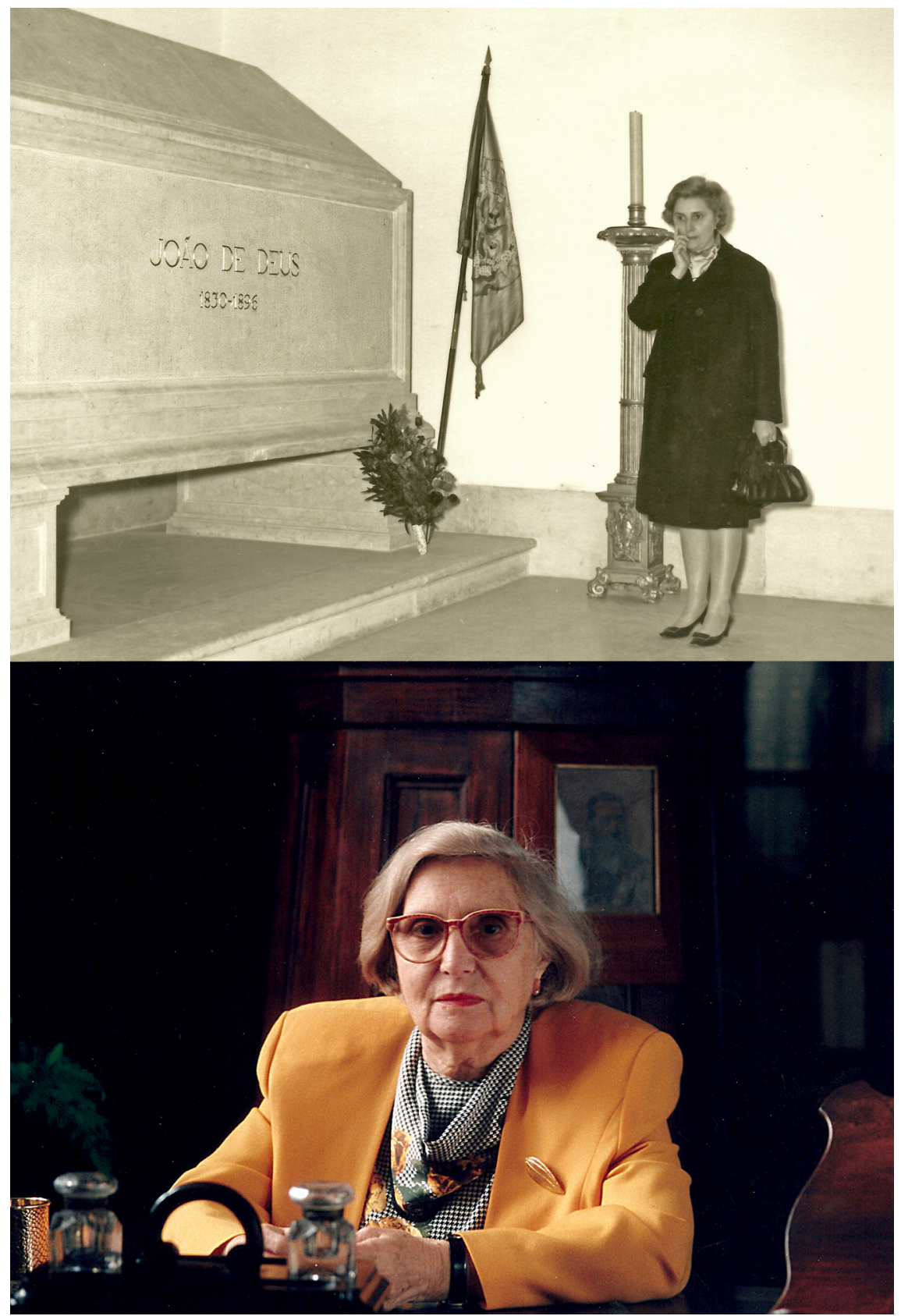

Fig.1: Maria da Luz de Deus Ramos junto ao túmulo de João de Deus, autor da Cartilha Maternal (Panteão Nacional).

Fig.2: Maria da Luz de Deus Ramos (Lisboa, 1918-1999). 


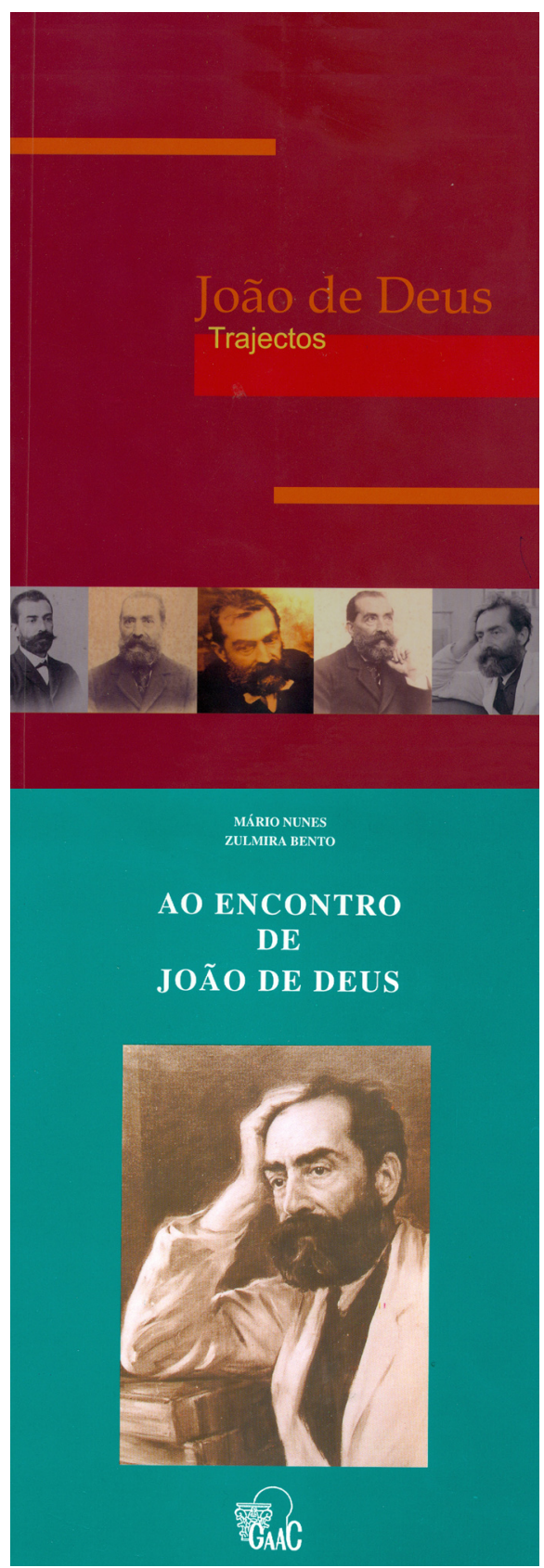

Fig.3: G. Rocha Martins (coord.), Trajectos do grés à arte da escrita, Silves, 2010.

Fig.4: Mário Nunes e Zulmira Bento, Ao encontro de João de Deus - na passagem do $1^{\circ}$ centenário da sua morte, Coimbra, 1996. 
A obra levada a cabo por Maria da Luz de Deus Ramos contribuiu para um crescimento exponencial da Associação.

\section{Legado:}

Organizou o $1^{\circ}$ Curso de Educadoras de Infância (1978/79 - 1980/81) na Região Autónoma da Madeira (1978); fundou o Comité Português da OMEP (Organização Mundial de Educação Pré-Escolar em (1979)e a Casa-Museu João de Deus Ramos em Lisboa (1982). Inaugurou um Centro de Alfabetização, assinalando os 86 anos da morte de João de Deus que funcionou na Casa João de Deus, sob a orientação do Prof. Dr. Albano Estrela (1982) e consolidou as estruturas da Escola Superior de Educação em Lisboa (1984). Inaugurou os Jardins-Escolas (19): Tomar (1955), Figueira da Foz (1958), Torres Novas (1960), $2^{\circ}$ Tomar (1962), Torres Vedras (1964, 1995 em edifício próprio), Lisboa-Alvalade/Tramagal/Estarreja (1965), Matosinhos (1969), Entroncamento (1971), S. Bartolomeu de Messines (1972), Urgeiça (1972, 1991 em edifício próprio com valência de creche), LisboaOlivais/Santo Tirso (1975), $2^{\circ}$ Coimbra (1980, comemoração do $150^{\circ}$ aniversário do nascimento de João de Deus), Braga (1984), Faro (1986), Penafiel (1981), Ponte de Sor (1996); Criou, ainda, Centro Infantil de Coimbra (1988).

De todas estas criações, merece destaque a Casa-Museu João de Deus em Lisboa, situada na Rua João de Deus, foi inaugurada no dia 11 de Janeiro de 1982 com o intuito de perpetuar a memória de João de Deus. Nesta casa, formou João de Deus muitos professores que colaboraram nas Escolas Móveis. Nesta casa, o poeta recebeu também a homenagem de Rei D. Carlos que o agraciou com a Gran Cruz de Santiago. Nesta casa, conheceu o último dia da sua vida.

No conjunto das iniciativas levadas a cabo por Maria da Luz de Deus Ramos e pelo vice-presidente o seu filho, António Ponces de Carvalho, destacamos ainda a Escola Superior de Educação João de Deus, um projecto educativo que se baseia no modelo humanista, orientado por princípios de solidariedade, entreajuda, cooperação, convivialidade, numa formação intensa e permanente. Esta ESE assume-se como uma extensão do projecto João de Deus, sendo uma entidade sem fins lucrativos e pertence à Associação de Jardins-Escolas (Instituição Particular de Solidariedade Social), que garante o funcionamento de 34 instituições distribuídas pelo país. Nascida da reconversão do Curso de Didáctica Pré-Primária pelo Método João de Deus, criado em 1920 pelo pedagogo João de Deus Ramos, filho do Poeta, este foi o primeiro e durante muito tempo o único espaço de formação para Educadores de Infância em Portugal, prestando um contributo decisivo na educação infantil.

A 9 de Novembro de 1988 foram criados os cursos de Educadores de Infância e de Professores do Ensino Básico - $1^{\circ}$ ciclo. Uma década passada, deu-se um 
nosso passo com a atribuição dos graus de licenciatura em Educação de Infância. Recentemente, desenvolveram-se vários cursos de complemento de Formação Científica e Pedagógica, bem como cursos de qualificação para o exercício de outras funções educativas - Administração Escolar, Administração Educacional e Orientação Educativa, que permite aos docentes com grau de bacharel a obtenção do de licenciatura. Esta instituição abraça sempre novos desafios e prova disso é o actual apoio ao desenvolvimento das Ciências da Educação na África Lusófona. O espírito nobre da metodologia de João de Deus consubstancia-se em princípios fundamentais, como o fomento à educação, a única garantia de igualdade e oportunidade de sucesso, o respeito activo e conciliador das diferenças culturais, na garantia de uma instrução e formação cívica e moral. Estes são os únicos valores que garantem vitalidade do projecto e a sua actualidade na sociedade. 


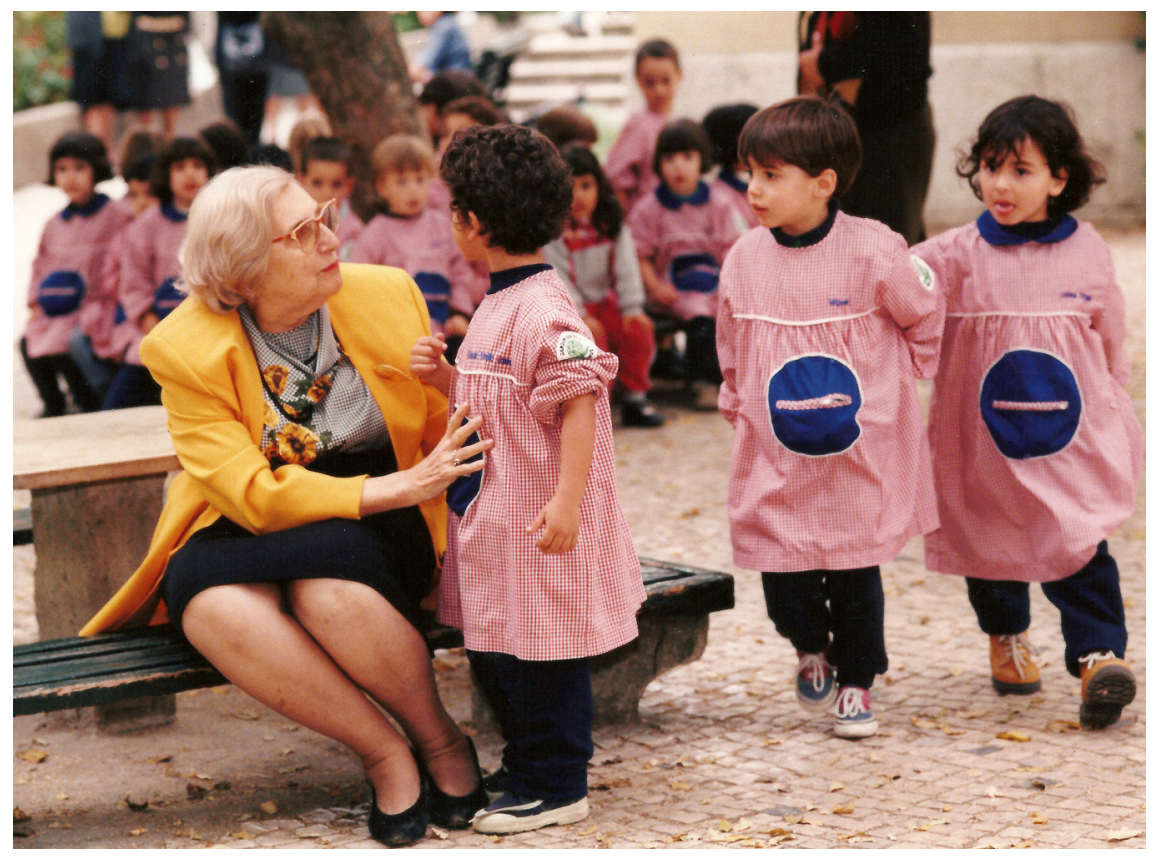




\section{António Ponces de Carvalho, actual presidente}

António Ponces de Carvalho assume a vice-presidência da Associação de Jardins-Escolas João de Deus em 1982 apoiando, desde então, a fundação e a consolidar várias estruturas escolares. Assume a presidência da mesma associação a partir 1999, ano de falecimento de sua mãe, Maria da Luz de Deus Ramos.

Nasce em Lisboa a 12 de Outubro de 1958. Do ponto de vista académico, inicia a sua formação com a licenciatura em Física - Ramo de formação educacional pela Faculdade de Ciências da Universidade Clássica de Lisboa, tendo realizado ainda o curso de Audiviosuais na Escola e obtido o Diploma de Professor Primário Particular. A nível internacional, obteve ainda o Diploma D'Études Approfondis concedido pela Universidade de Caen e pelo Curso de coordenação de actividade docente no Instituto de Ciências de la Educacion da Universidade de Navarra.

No âmbito profissional, o neto de João de Deus Ramos reúne uma vasta e ecléctica experiência: leccionou Cursos de Formação Contínua e Cursos de Formação Especializada de Professores, acreditados pelo Conselho Científico de Formação Continua de Professores e Financiados pelo Programa Foco do Ministério da Educação (desde 1996), tendo também ministrado cursos de formação para professores em Cabo Verde, São Tomé e Princípe e Angola-Huambo. Organizou e participou em diversas viagens de estudo, visitando cerca 73 escolas um pouco por todo o mundo, e cursos de formação contínua de professores. Desde 1982, organiza em conjunto com o Hospital de D. Estefânia, organiza, desde 1992, 16 cursos de férias para crianças asmáticas, em Gouveia Destacamos ainda a participações nos média, nomeadamente os dois anos e meio em que escreveu uma coluna de opinião semanal no jornal "Diário Económico", bem como nos programas quinzenais na RTP 2 - "Tudo em Família”, desde Novembro de 2004 e, posteriormente, no Programa Sociedade Civil (RTP2), assim como nos canais Sic, Sic-Notícias, RTP1 e TVI. Em virtude da vasta experiência como pedagogo, sua intensa dedicação à causa pedagógica e à sua notoriedade enquanto pensador neste âmbito, foi convidado pelo Conselho europeu para participar nos seguintes eventos: Conferência "Évolution du Rôle des Enfants à la Vie Familiale: Participation et Négociation”, Palácio dos Congressos de Madrid (1994); Conférence de Clôture du Projet "Politiques de l'Enfance" - "Les droits des enfants et les politiques de l'enfance en Europe: de nouvelles approches?”, organizado pelo Council of Europe, conjuntamente com o Ministério Federal 
Alemão da Família, das pessoas de idade, da condição feminina e da juventude, Leipzig (1996) e finalmente, em 2000, para Conferência intitulada "Les Enfants à l'aube d'un Nouveau Millénaire", Nicosie, Chipre (2000).

Preside, desde 1999, à Direcção da Associação de Jardins-Escola João de Deus, à Escola Superior de Educação João de Deus e ao Comité Português da OMEP (Organização Mundial de Educação Pré-Escolar).

O seu compromisso com a sociedade e com o grande projecto humano que é a educação para a dignificação do homem tem sido alvo de reconhecimento público, tendo sido agraciado com o Grau de Comendador da Ordem de Mérito de Instrução Pública, por Sua Excelência o Presidente da República, Dr. Jorge Sampaio (2005) e no mesmo ano agraciado por S.A.R. Dom Duarte Nuno de Bragança com o Grau de Comendador da Ordem de S. Miguel da Ala, fundada em 1147 (2005). 


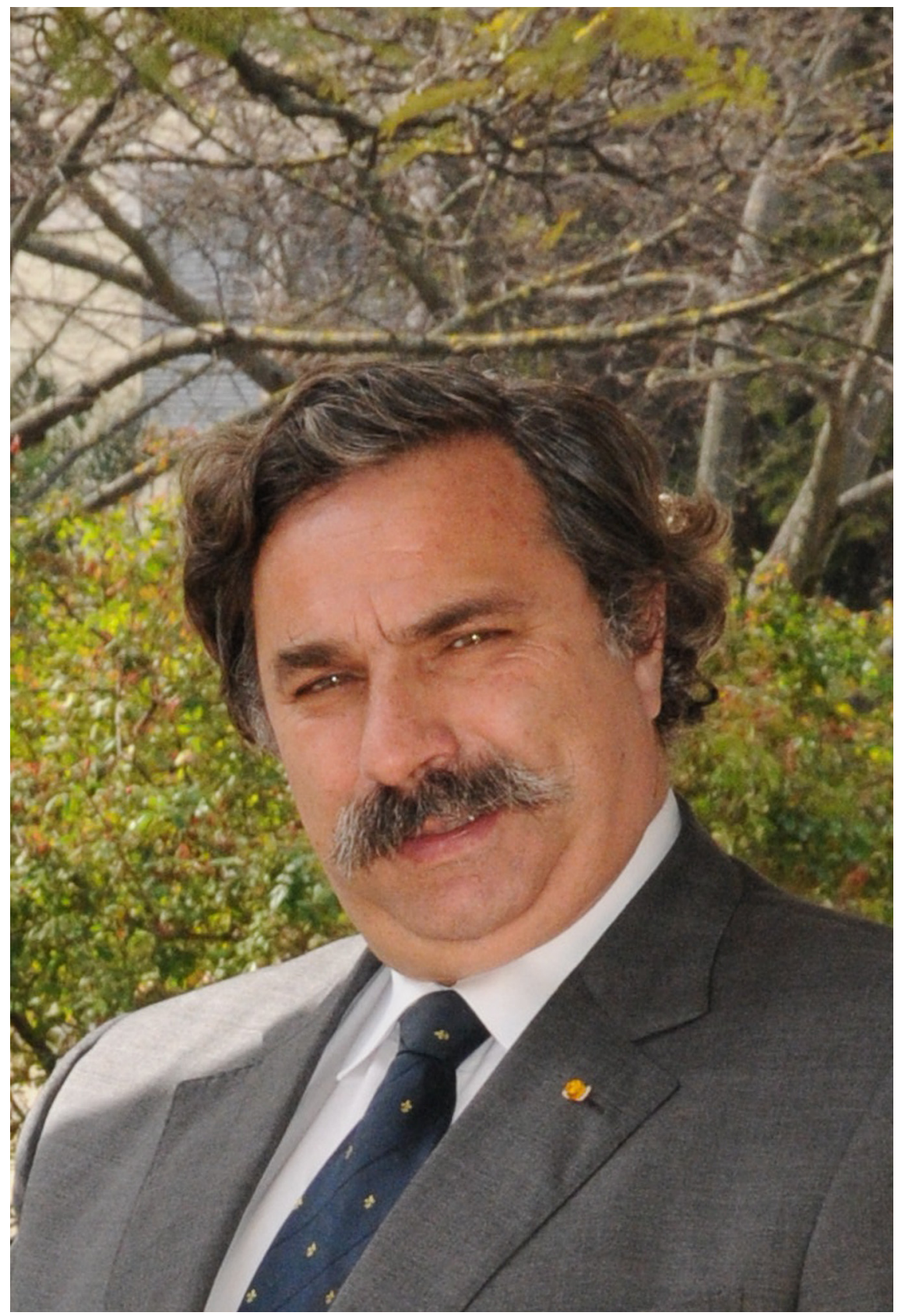

Fig.6: António Ponces de Carvalho, bisneto do poeta João de Deus. 


\section{Contributos para a Instituição até ao momento (2011):}

$\mathrm{Na}$ qualidade de vice-presidente da Associação de Jardins-Escolas João de Deus (desde 1982), ajudou a fundar as estruturas escolares com a sua mãe: Jardim-Escola João de Deus Braga (1984), Escola Superior de Educação João de Deus (1984), Jardim-Escola João de Deus em Faro (1986), Centro Infantil de Coimbra (1988), Jardim-Escola João de Deus em Penafiel (1991), Jardim-Escola João de Deus em Ponte de Sor (1996), Jardim-Escola João de Deus Torres Vedras (1995).

Depois de assumir o cargo de Presidente em 1999, criou as seguintes: JardimEscola João de Deus em Albarraque (2000), Jardim-Escola João de Deus em Santarém (2003), Jardim-Escola João de Deus no Funchal (2003), Centro Infantil de Lisboa I em Alvalade (Janeiro 2005), Centro Infantil de Lisboa I (Setembro 2005), Jardim-Escola João de Deus em Vila Nova de Gaia (2005), Centro Infantil da Figueira da Foz II (2007) e o Jardim-Escola João de Deus em Tavira (2008), Casa Rainha Santa Isabel em Odivelas (2009). A sua acção tem sido desenvolvida em vários quadrantes: Coordenação o grupo de trabalho responsável pela criação da Escola Superior de Educação João de Deus; Modernização da Associação de Jardins-Escola João de Deus criada há 126 anos.; Criação em 2002, as Ludotecas itinerantes João de Deus para ajudar a combater a exclusão social em bairros de população menos favorecida: Ludoteca I (2002), Ludoteca II (2003); Criação do Projecto de Actividades Educativas e Culturais João de Deus, um anfiteatro destinado à realização de actividades educativas e culturais por crianças e jovens.

Destas criações, merece destaque a criação da Casa-Museu em S. Bartolomeu de Messines, terra natal do poeta João de Deus. Situado na Rua Dr. Francisco Neto Cabrita ${ }^{\circ}{ }^{1}$, este espaço foi inaugurado no dia 25 de Outubro de 1997, recebeu apoio da Câmara Municipal de Silves e a recuperação da casa ficou a cargo do Arquitecto Mário Varela. A Casa-Museu divide-se em duas vertentes: o espaço museológico que recria a casa e que conta com uma exposição permanente e o espaço da biblioteca com sala de leitura e hemeroteca. 


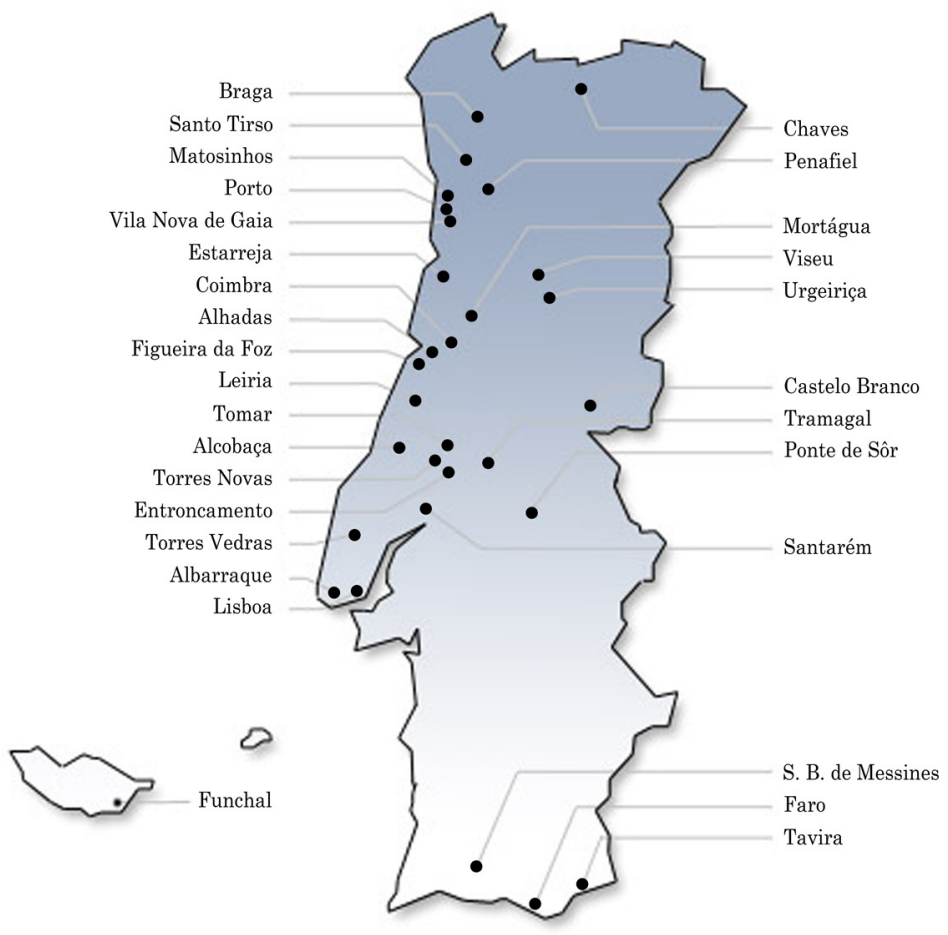

Fig.7: Rede Nacional de Jardins-Escolas João de Deus. 


\section{Primeiro Jardim-Escola João de Deus:}

\section{$A$ VIDA É O DIA DE HOJE}

A vida é o dia de hoje, $A$ vida é ai que mal soa, $A$ vida é sombra que foge, $A$ vida é nuvem que voa;

$A$ vida é sonho tão leve Que se desfaz como a neve E como o fumo se esvai: $A$ vida dura um momento, Mais leve que o pensamento, $A$ vida leva-a o vento, A vida é folha que cai!

A vida é flor na corrente, $A$ vida é sopro suave, $A$ vida é estrela cadente, Voa mais leve que a ave:

Nuvem que o vento nos ares, Onda que o vento nos mares, Uma após outra lançou, $A$ vida - pena caída Da asa da ave ferida De vale em vale impelida $A$ vida o vento levou! João de Deus Ramos (1830-1896) 


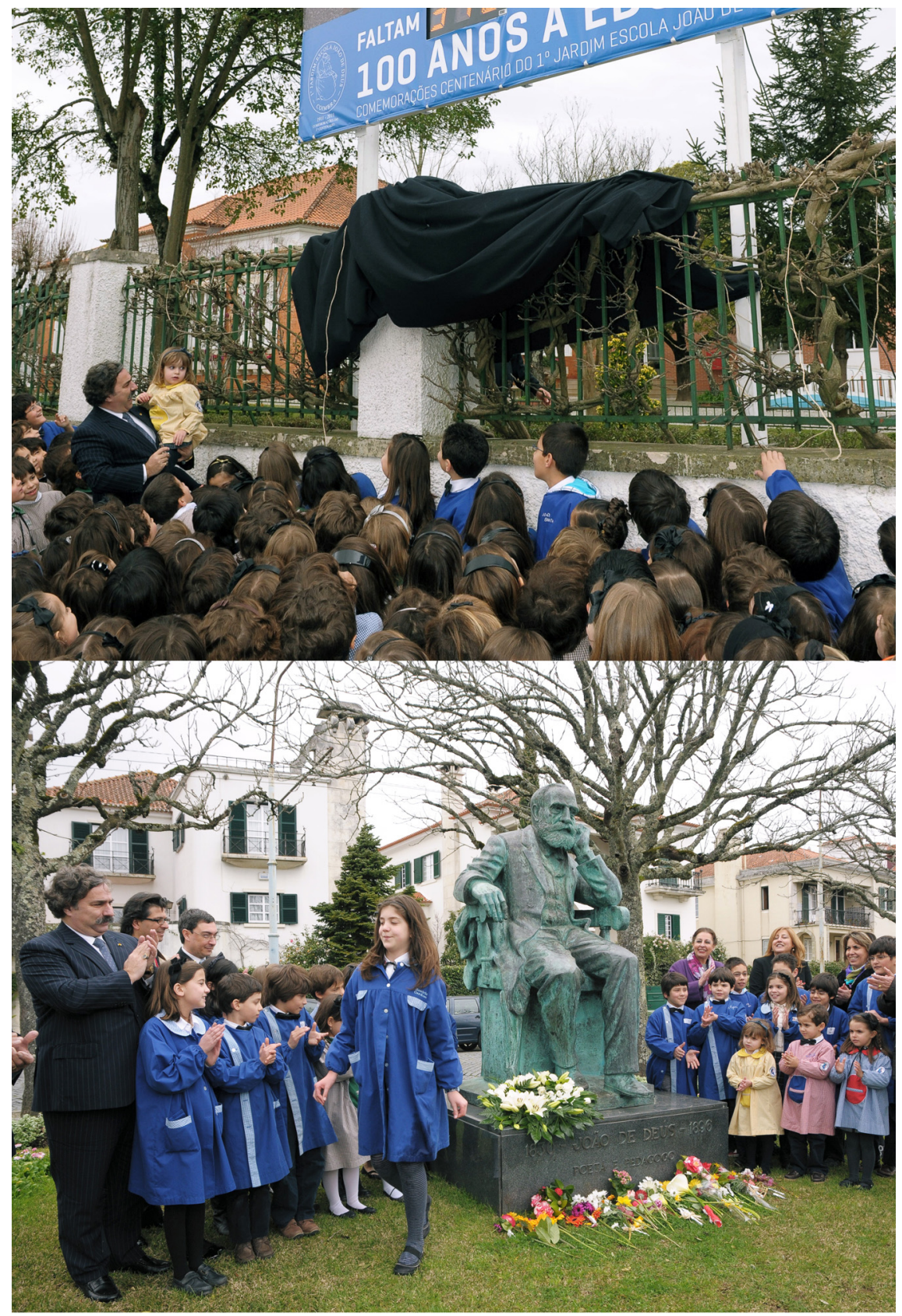

Fig.9 e 10: Início da celebração do centenário do primeiro Jardim-Escola João de Deus. 

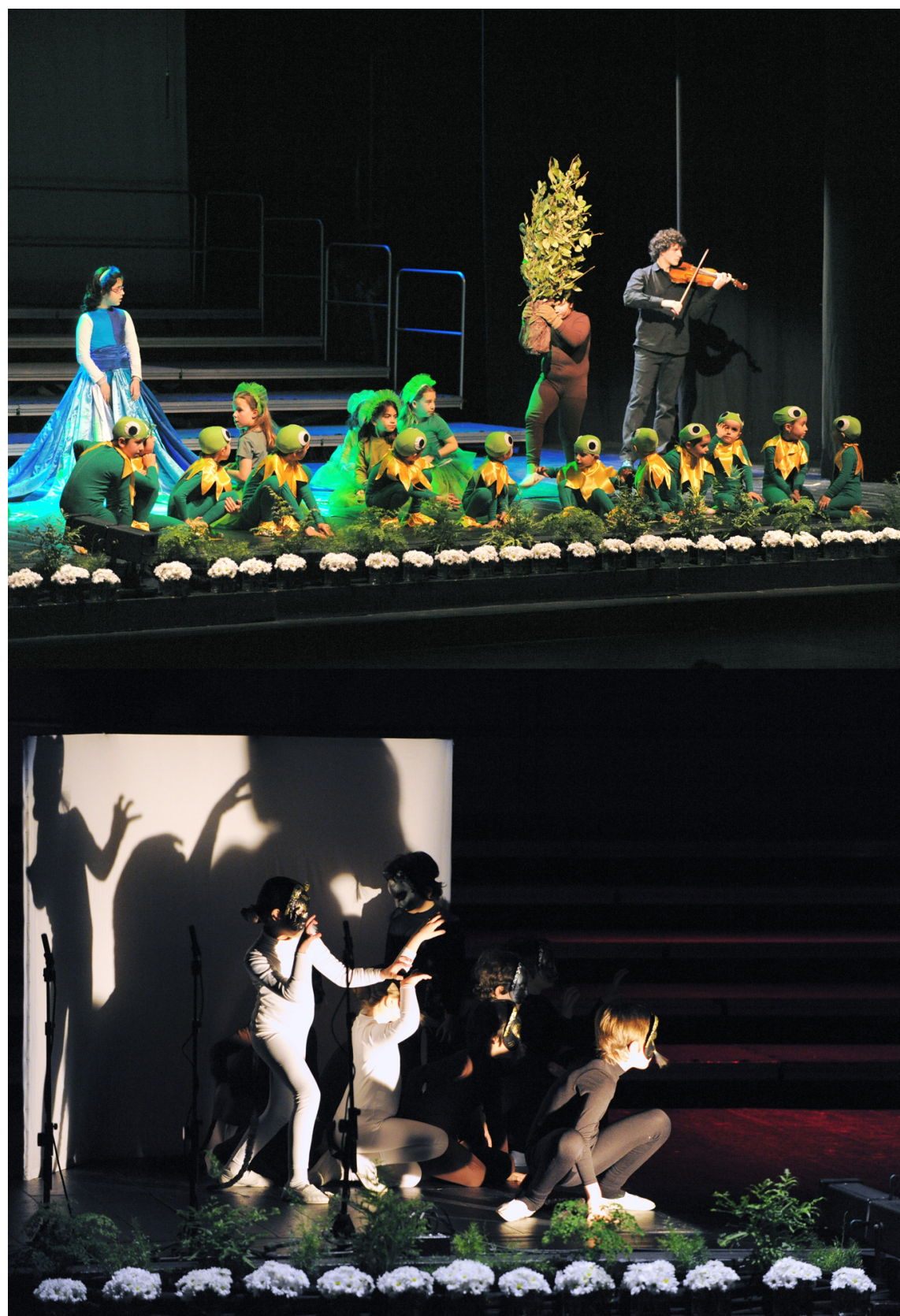

Fig. 11: Dramatização da fábula de João de Deus, As Rãs clamam por um Rei. Teatro Académico Gil Vicente, 2010.

Fig.12: Dramatização da fábula de João de Deus, Os Ratos reunidos em Conselho. Teatro Académico Gil Vicente, 2010. 
Além da descoberta da leitura, as crianças contactam, pela primeira vez, com a matemática aos três anos de idade por intermédio de uma interacção concreta e experimentada de materiais didácticos. A manipulação destes objectos, sejam eles os calculadores multibásicos, os Dons de Froëbel, os geoplanos ou blocos lógicos constitui um meio de desenvolvimento da sua aprendizagem, conforme Maria Filomena Caldeira (2009, p.15) sublinha: "Esta é a forma de tornar possível novas maneiras de ser e fazer resultando de um objectivo e de um processo que proporcionará através de diferentes graus de implicação, trocas com o meio ambiente material e social. O princípio básico referente ao uso destes materiais consiste em manipular objectos e "extrair" princípios matemáticos que são abstractos".

No processo da educação, saber como se aprende matemática é essencial. A actividade matemática mobiliza uma linguagem própria e uma simbologia adequada e estas representações mentais ocorrem quando pensamos e/ou falamos do objecto ou processo matemático. A representação simbólica é falada ou escrita e deve facilitar a comunicação do conceito; a representação mental refere-se a esquemas internos de cada indivíduo que representam um conceito e que para proporcionar sucesso em matemática devem permitir a visualização de diferentes representações mentais do mesmo.

A componente intuitiva utiliza a imaginação, a visualização e todas as nossas vivências. O conhecimento intuitivo na matemática é aquele que é próprio de cada indivíduo, que transporta sentimentos de certeza e vai além dos factos que são acessíveis. (2009, pp. 46, 59). 


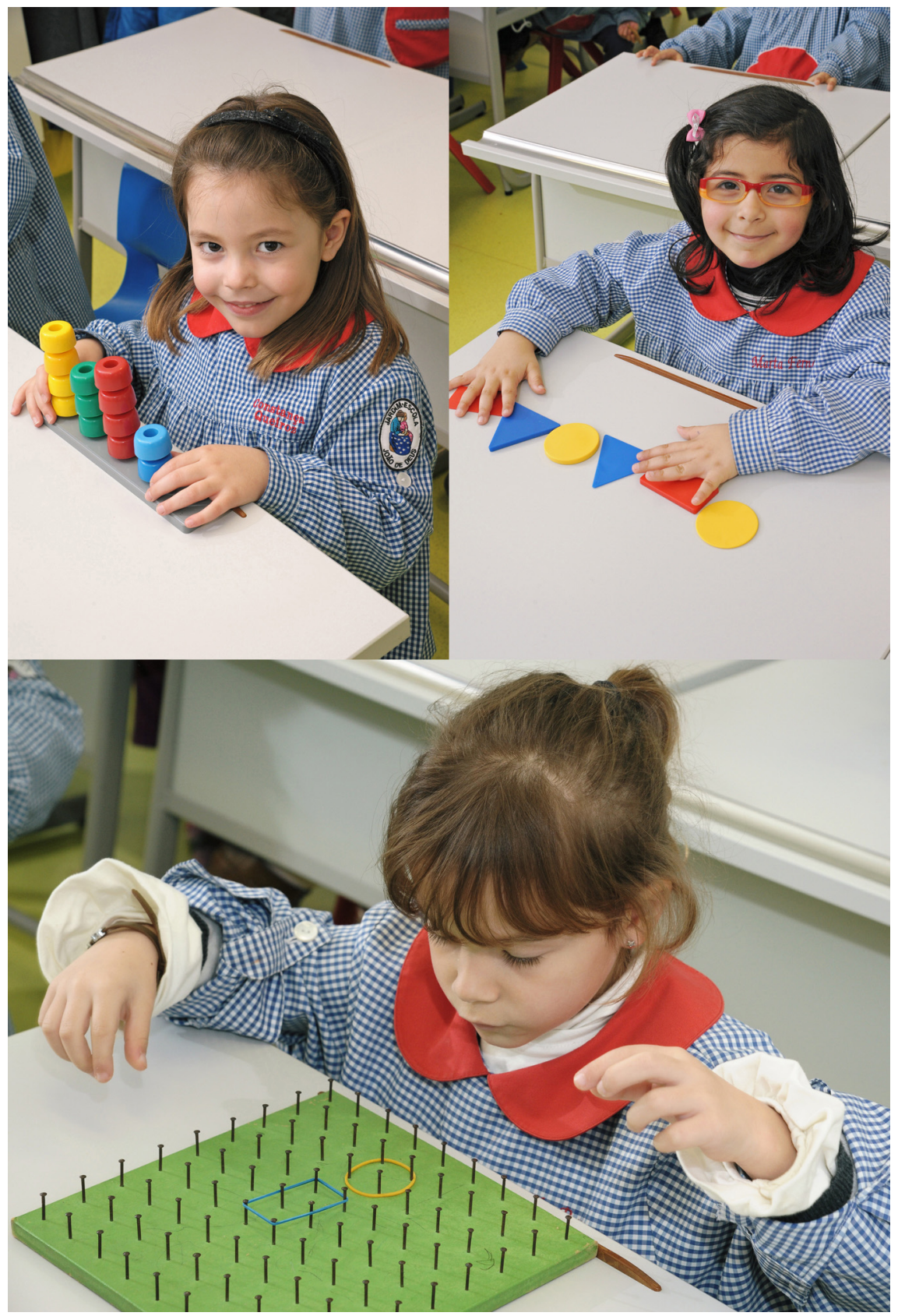

Fig.13: Aluna do Bibe Azul (5 anos) na aula de matemática com os Calculadores Multibásicos.

Fig.14: Aluna do Bibe Azul ( 5 anos) numa aula de matemática com Blocos Lógicos. Fig.15: Aluna do Bibe Azul (5 anos) a realizar um exercício no Geoplano. 


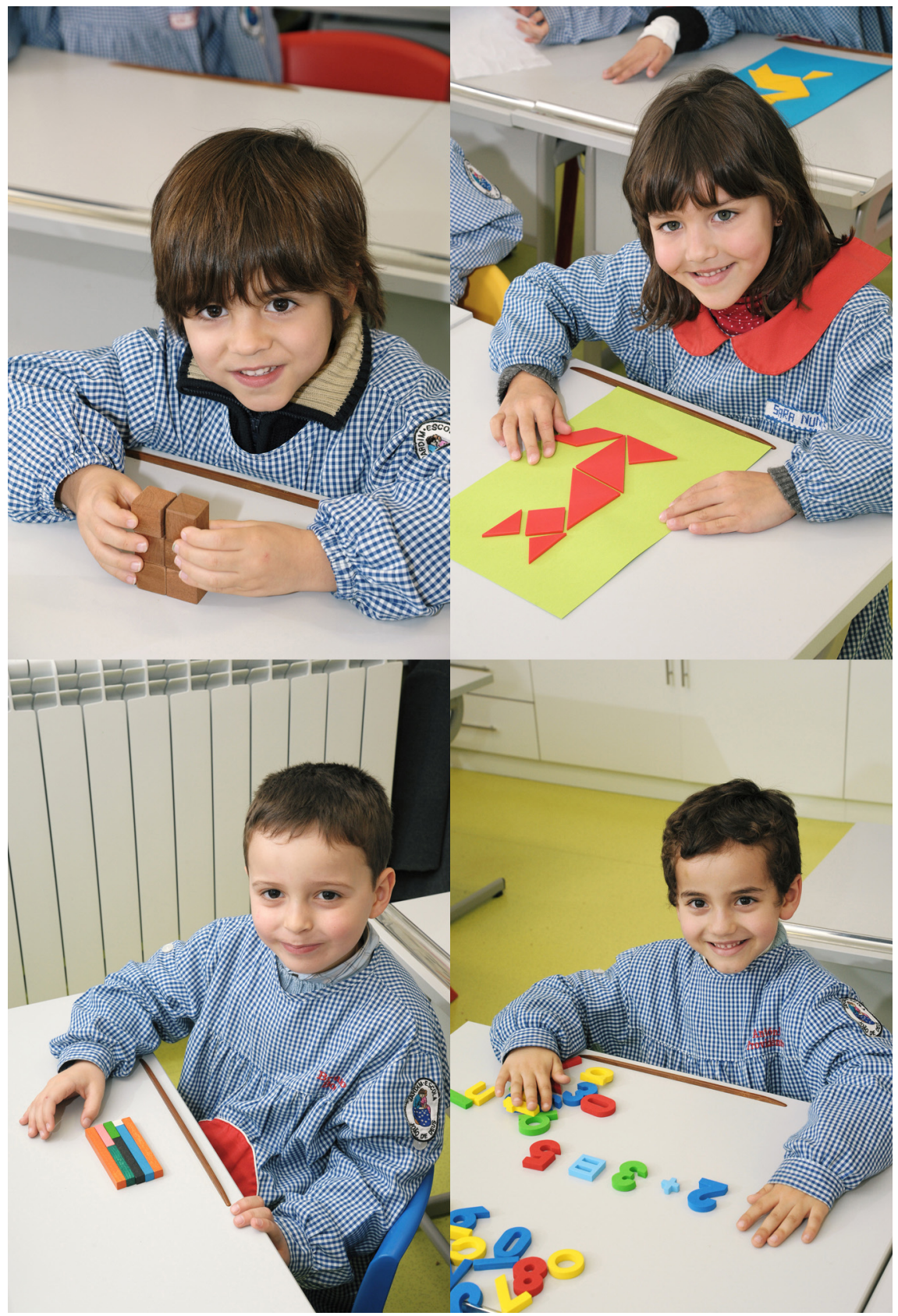

Fig.16: Aluno do Bibe Azul ( 5 anos) na aula de matemática com o $3^{\circ}$ dom de Fröebel.

Fig. 17: Aluna do Bibe Azul (5 anos) a realizar um exercício de matemática Tangran.

Fig. 18: Aluno do Bibe Azul ( 5 anos) a realizar um exercício com Cuisenaire.

Fig. 19: Aluno do Bibe Azul ( 5 anos) na sala de aula a realizar um exercício de matemática. 
No bibe azul

a cartilha aprendemos,

os primeiros livros lemos

e as primeiras letras escrevemos

Começando nas vogais

$E$ depois as consoantes

Seguiram-se os textos restantes

Para ele foi uma filha.

Assim aprendi a ler

E gosto de o fazer

Ler é divertido

No livro tenho um amigo

Turma $4^{\circ} \mathrm{A}$ do $1^{\circ}$ Jardim-Escola João de Deus

No bibe amarelo

entrámos para o nosso castelo,

onde todos criámos um elo

e começámos um sonho belo.

Turma $4^{\circ} \mathrm{A}$ do $1^{\circ}$ Jardim-Escola João de Deus 
Um dia João de Deus,

Sem ter nada que fazer

Pegou numa folha

E começou a escrever

Um livro que ensinava

As crianças a ler.

Leu, releu

Gostou do que escreveu

Resolveu dar ao livro

$O$ nome de Cartilha.

Beatriz Arcanjo, aluna do $1^{\circ} \mathrm{Jardim}-E s c o l a$

Nesta escola gostava de ficar

Mas o meu tempo está a acabar

Nela aprendi a ler

Dela levo todo o meu saber

Que me ajudará a crescer

Beatriz Arcanjo, aluna do $1^{\circ} \mathrm{Jardim}-\mathrm{Escola}$ 


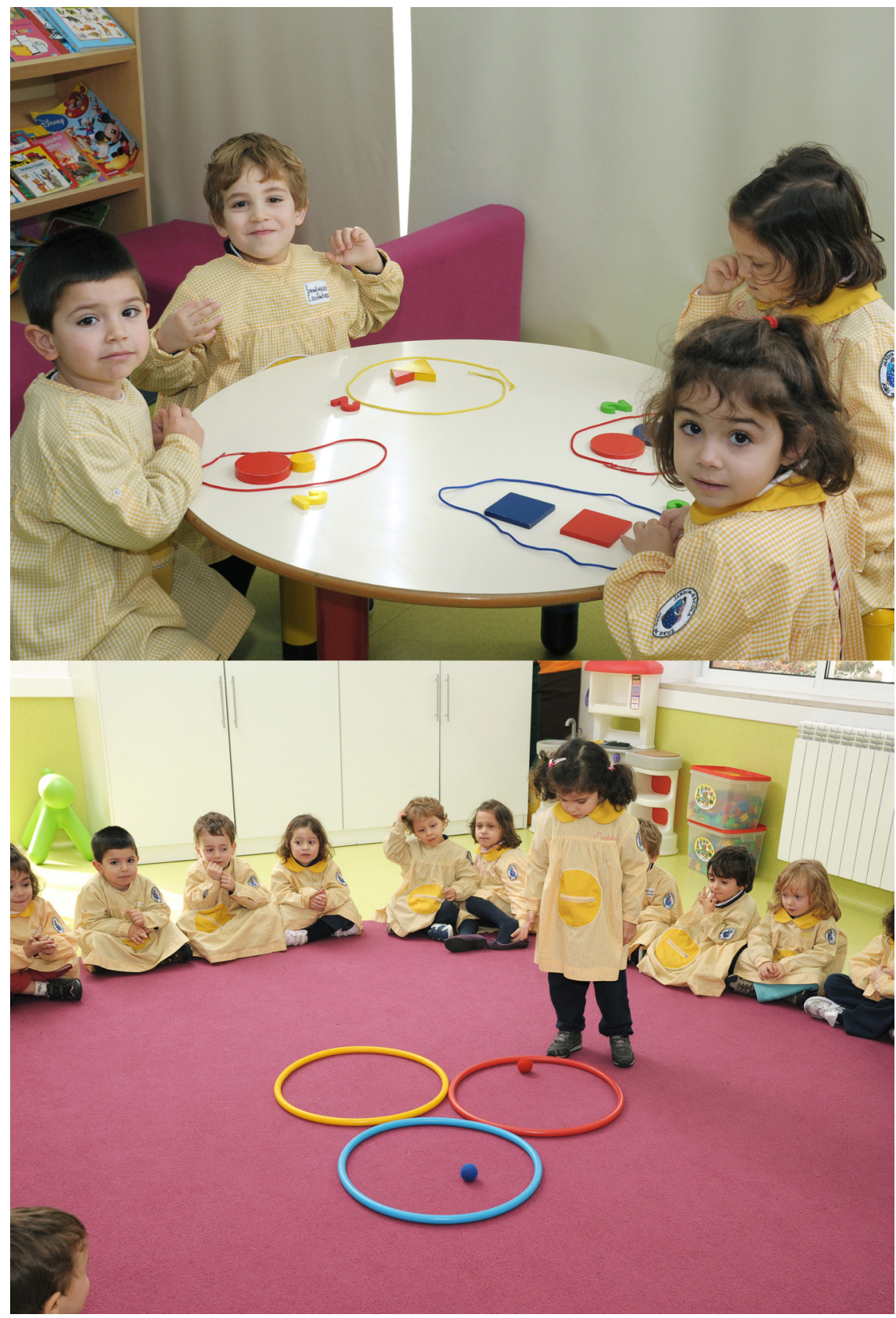

Fig.20: Grupo de alunos do Bibe Amarelo (3 anos) na aula de matemática a realizar um exercício com Blocos Lógicos.

Fig.21: Grupo de alunos do Bibe Amarelo (3 anos). O $1^{\circ}$ Dom de Fröebel e a aprendizagem das cores. 


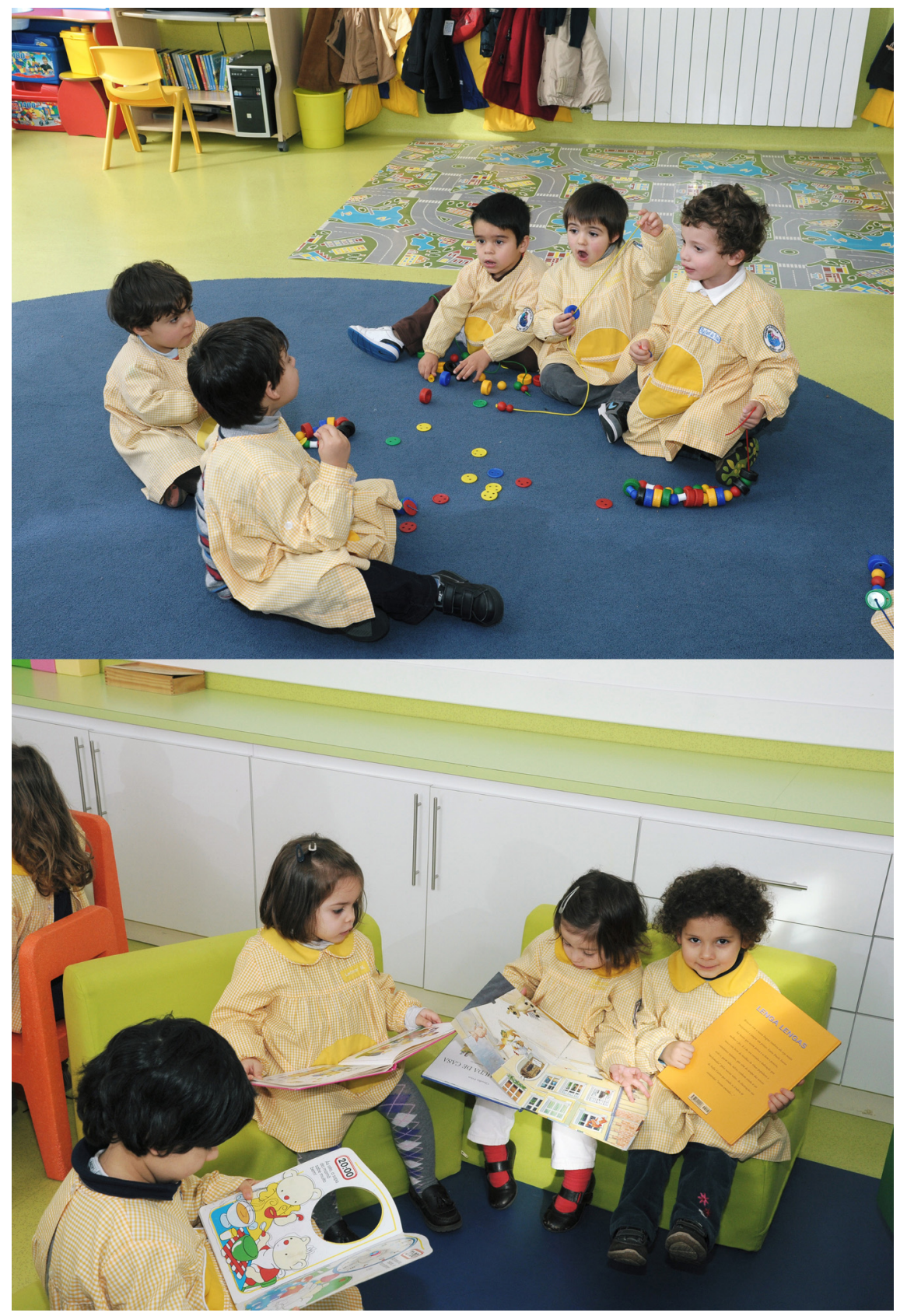

Fig.22: Grupo de alunos do Bibe Amarelo (3 anos) a realizar um exercício com enfiamentos.

Fig.23: Grupo de alunos do Bibe Amarelo (3 anos) na biblioteca. 


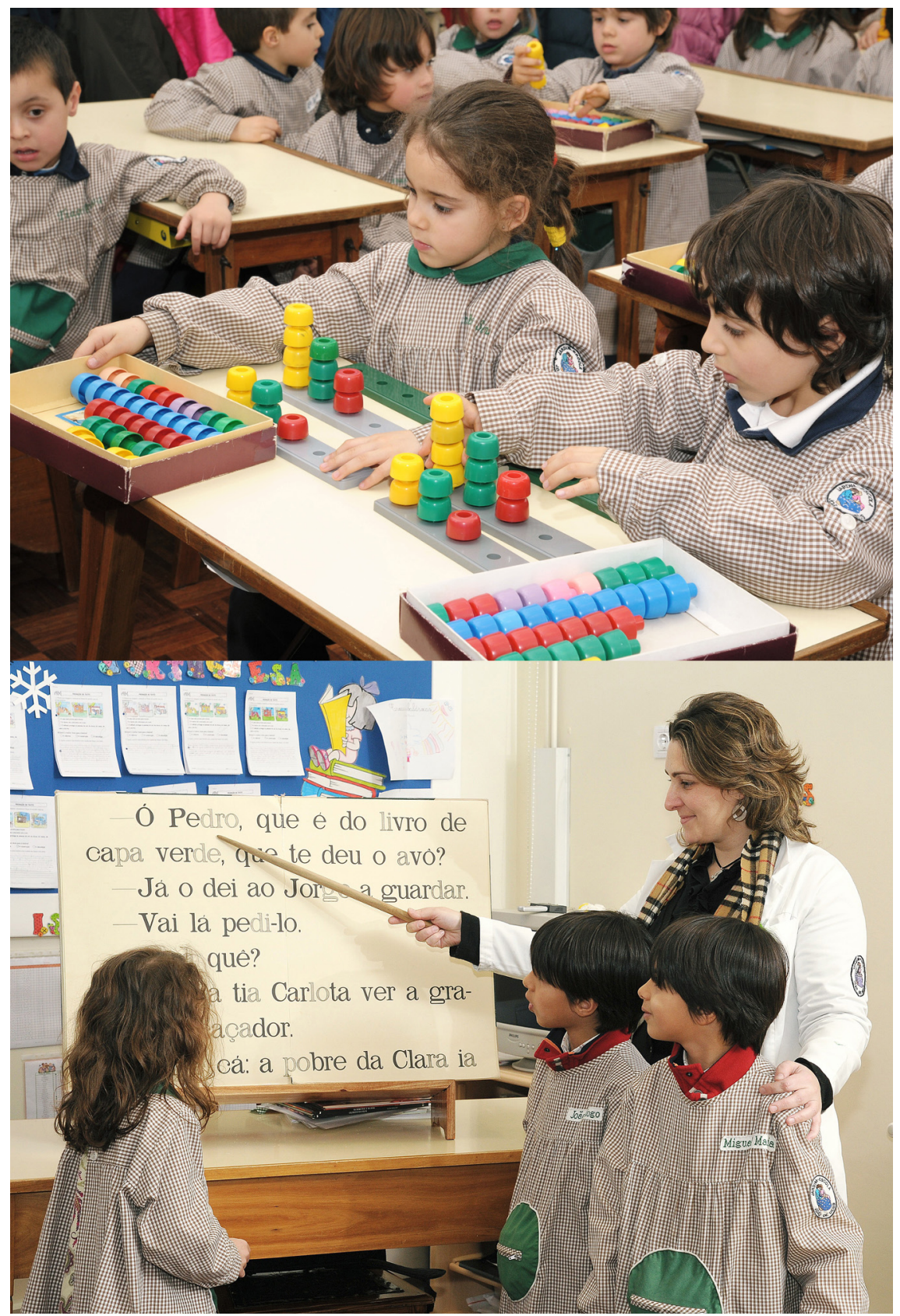

Fig.24: Alunos do $1^{\circ}$ ano na aula de matemática, utilizando calculadores multibásicos. Fig.25: Professora e três alunos do $1^{\circ}$ ano a realizar um exercício de leitura na Cartilha Maternal. 


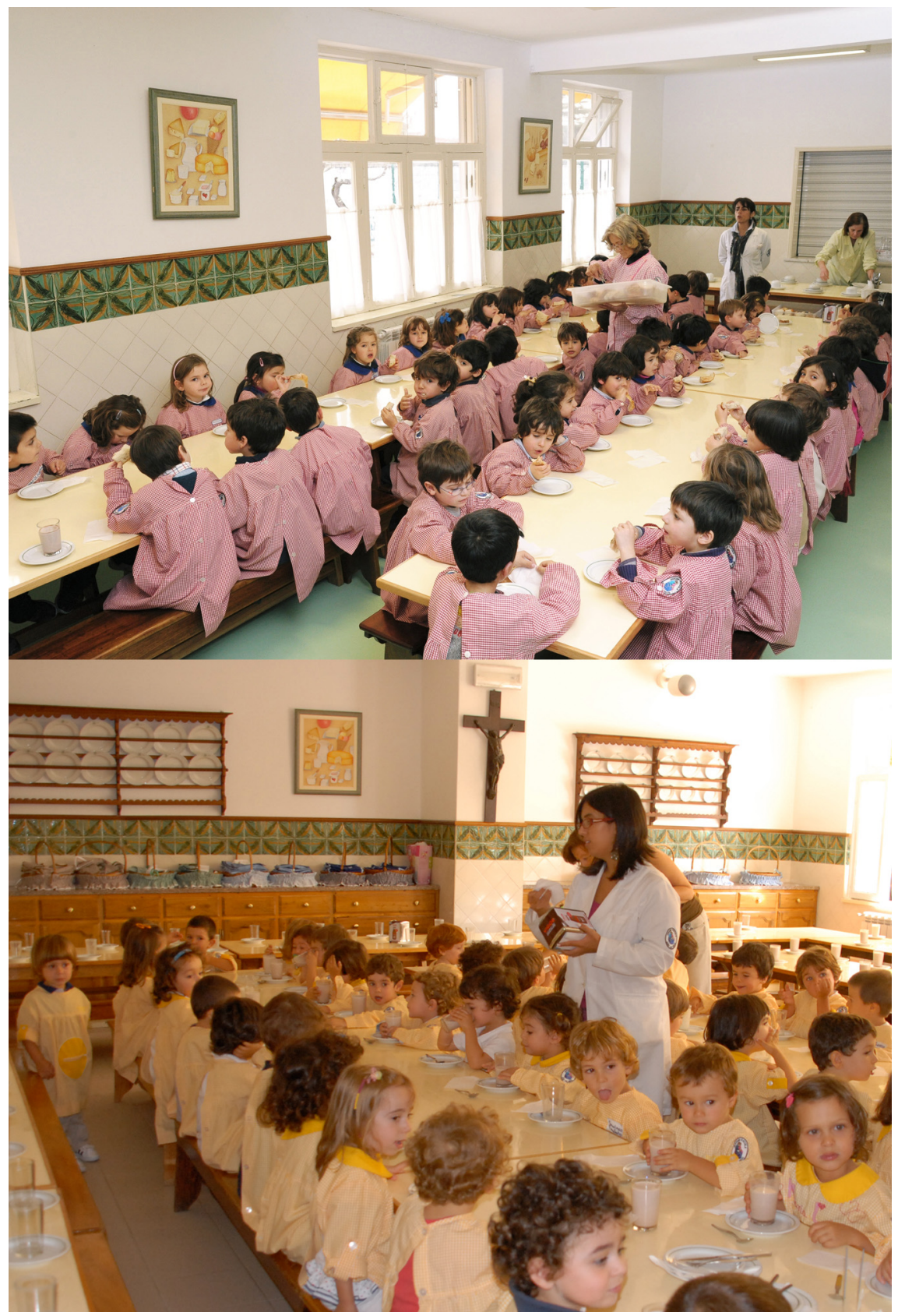

Fig.26 e 27: Alunos na hora do lanche na cantina. 


\section{O $1^{\circ}$ Jardim-Escola João de Deus, 1911-20...}

Há cem anos atrás, a adesão das camadas populares foi muito significativa, todos tinham o seu lugar e "cem, sim, são cem, pelo menos, as crianças inscritas, e teve a comissão o desgosto de verificar que outras tantas teriam vindo se outra escola houvesse", conforme relatou Gustav Adolf Bergströn (1912, p. 93).

Hoje, o primeiro Jardim-Escola João de Deus conta com 361 alunos. Além do curriculum normal, há registos de ter oferecido disciplinas como francês, ginástica e música já na década de 40 e 50 . Na década de 80 , seguem-se inglês, ballet e informática e expressão dramática na década de 90 . Actualmente, a escola oferece actualmente actividades extra-curriculares de judo, ténis, ciência divertida, inglês e oficina de escrita criativa. O sector Pré-Escolar é composto por duas secções: a primeira é constituída por duas classes, a do Bibe Amarelo (3 anos) e a do Bibe Encadernado (4 anos); a segunda secção corresponde ao Bibe Azul (5 anos). Este primeiro sector reúne cerca de 158 alunos. Quanto ao $1^{\circ}$ ciclo do Ensino Básico, desde $1^{\circ}$ ao $4^{\circ}$ ano, conta com 203 alunos.

Em relação ao pessoal docente, o mais antigo Jardim-Escola do país reúne cerca de 23 professores, além de 16 funcionários não docentes.

E, para coroar a excelência do projecto educativo desenvolvido pelo $1^{\circ}$ Jardim-Escola, a Câmara Municipal atribuiu a Medalha de Ouro da Cidade de Coimbra por ocasião das comemorações do Centenário, aprovada na Assembleia Municipal no dia 2 de Março de 2011. 


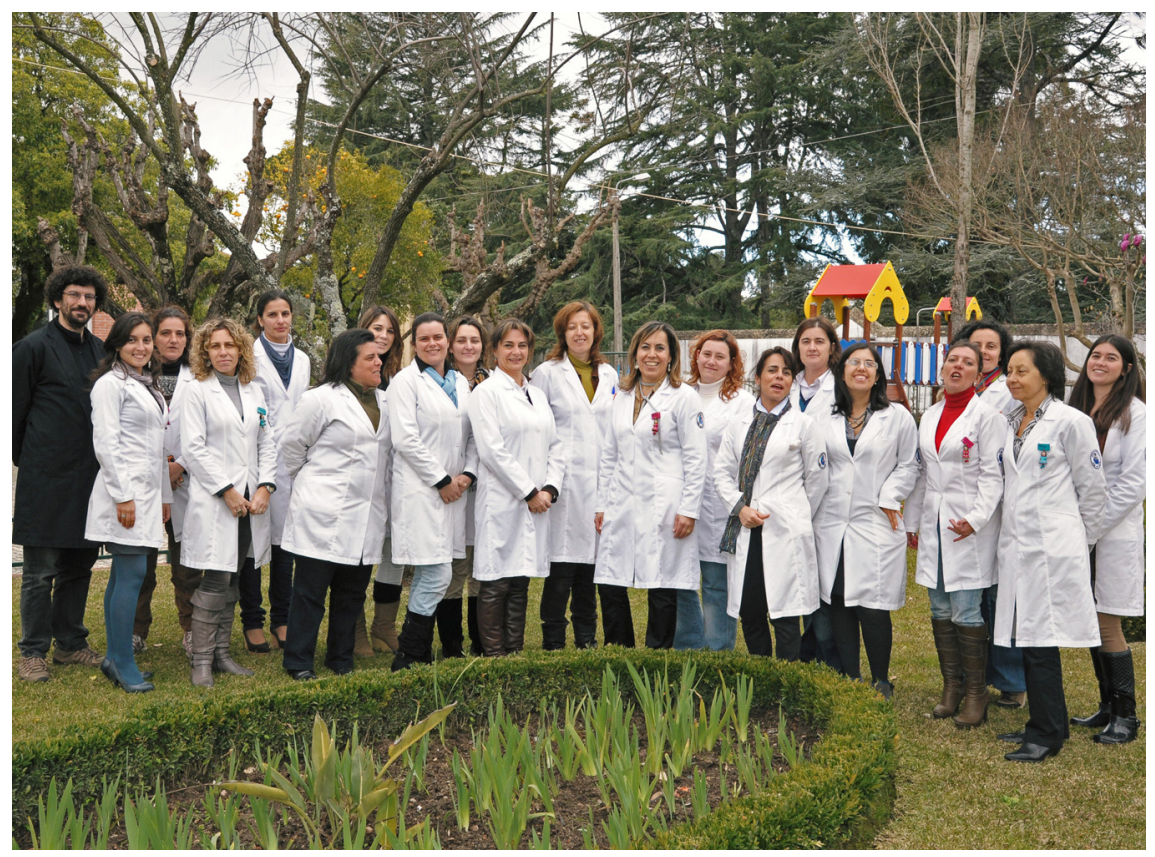

Fig.28: Da esquerda para a direita: Luís Pedro, Tânia, Anabela Dulce, Sandra Campos, Paula Santos, Amélia Saraiva, Maria Manuel, Sofia, Sandra Carvalho, Teresa; atrás da esquerda para a direita: Alexandra, Paula Ferreira, Joana, Filipa Alvoeiro, Maria João, Vanessa, Alzira, Maria, Filipa Silva. 


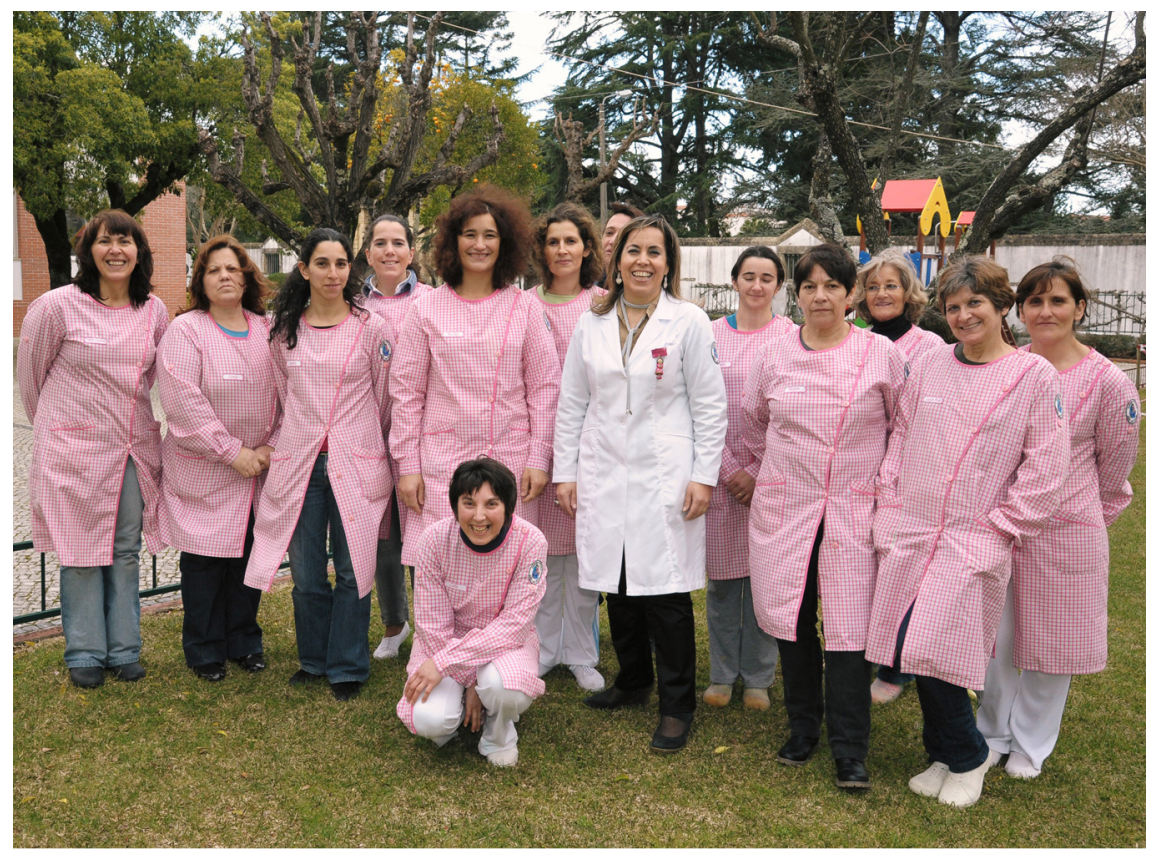

Fig.29: Da esquerda para a direita: Odete, Licínia, Sandra, Ana, Anabela, Néli, Ma Jorge, Cláudia, Minda, Clara; ao meio, a directora Amélia Saraiva, ao lado, Regina, Lurdes; em baixo, Carla. 


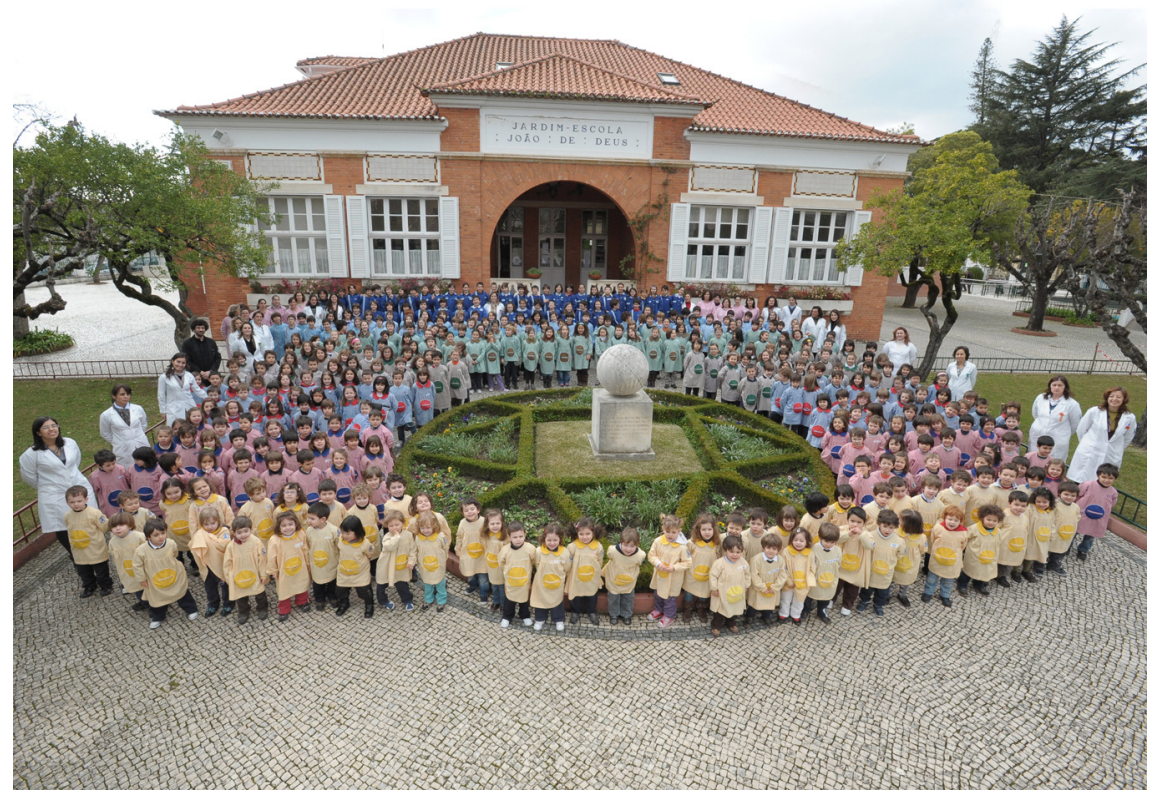

Fig.30: Crianças, professoras e funcionários do $1^{\circ}$ Jardim-Escola João de Deus (2011). 


\section{Cem anos}

Cem anos e um mundo de Poesia! Anos, cujos sonhos voaram tantas vezes recortados nas palavras, alados nos pensamentos, anos que deram lugar a um turbilhão de sentimentos e construíram a beleza de um voo livre e feliz de cada criança que passou por este Jardim-Escola!

Cem anos decorridos são. Agora, uma imensidão de emoções. A alegria e entusiasmo, a consciência da responsabilidade animam o coração e o espírito de quem tem o privilégio de trabalhar neste jardim onde, diariamente, perscrutamos magias e encantos tamanhos de felicidade partilhada pelo sentir dos "Filhos de João de Deus".

Hoje, como há cem anos, a cidade traduz o seu reconhecimento participativo, carinhosamente envolvida nesta centenária história de amor. Orgulhamo-nos, pois, da colaboração que entidades e instituições suas emprestam aos nossos projectos. E esta é uma história que continua, promissora. A "Casa Mãe”, bem consciente da riqueza do seu passado, vive o tempo presente com a constante e superior dedicação e empenho em crescer, em inovar, perspectivando um caminho de excelência para o futuro.

A vida desta instituição e o segredo do seu sucesso residem na partilha, na confiança, na interacção com as Famílias dos nossos alunos, em quem encontramos a validação dos valores e ideais com que o Jardim-Escola, desde a sua raiz, tem formado gerações sucessivas de crianças para uma sociedade mais perfeita, mais justa e esclarecida. A todas as Famílias o nosso louvor, porque acreditam em nós!

Cem anos representam, agora, a oportunidade ímpar de olharmos o passado com muito orgulho e, assim, projectarmos um rumo para as gerações vindouras, para a construção de uma Sociedade em que o Conhecimento seja sustentado naqueles que são os princípios e os valores intemporais de tolerância, respeito e igualdade na diversidade, de que era defensor João de Deus Ramos.

Maria Amélia Saraiva, actual directora pedagógica do $1^{\circ} \mathrm{Jardim}-\mathrm{Escola}$ 


\section{SABEDORIA POÉTICA E UTOPIA INSPIRAdORA}

A celebração do primeiro dos séculos insinua-se, quase sempre, como uma janela escancarada para o futuro, é uma feliz síntese que se abre de forma inspiradora aos novos desafios. Com a memória condensada e sem saudosismos, o $1^{\circ} \mathrm{Jardim}-\mathrm{Escola}$ João de Deus deixa cair os penachos e demanda, como um rio vivo sulcando gerações, a geografia de valores e de afectos que inspiraram o imaginário dos construtores desta catedral, simbolicamente habitada pelos melhores de nós: as crianças. Ao esculpir-se a efeméride com este livro de cumplicidades mas, principalmente, de tolerância plural, todos nos identificamos com o projecto visionário do poeta João de Deus, que soube salpicar o seu tempo com as suas ideias, as suas palavras, os seus amigos, os seus familiares, recuperando para a utopia o olhar e a marca poética, onde "saber ler é ser homem". Inaugurado a 2 de Abril de 1911, desde logo num diálogo ininterrupto com a obra pombalina, o Jardim Botânico trazia, já, o conceito perene de uma reforma urgente que atravessasse o efémero e que muito inquietou os idealistas e desassossegou os incrédulos. É a Obra, com maiúscula, porque encerra o ideário republicano da democratização do ensino, porque materializou o traço estruturante e indelével de Raul Lino, porque se ergueu com mesura e solidariedade, porque ao longo de um século irradiou sabedoria e, hoje, tem outros irmãos no continente e nas ilhas: a rede de Jardins-Escolas. A Obra inacabada atravessou cem anos. O desafio, agora, é agigantar a imaginação e crescer, dilatando o raio com a cumplicidade da sua força. A exposição, O Primeiro dos Centenários, pretende ser um olhar comprometido com a História, e convocar as pessoas que ajudaram nessa senda, sulcando a intimidade da viagem nesse tempo de emoções e de ansiedades, um filme onde se sente a presença de todos os que habitaram o pórtico desta história feliz. Cada instante, cada imagem, cada frase foram escolhidos para construírem o arco de tempo, capaz de unir todos os que partilharam a segmentação dessa viagem que nos une e honra. É, por isso, justo e merecido lembrar que a Directora do $1^{\circ}$ Jardim-Escola João de Deus, alma mater destas comemorações, a Professora Amélia Saraiva, é, também, a décima, desde a sua fundação. Sem a sua incansável dedicação e persistência, este centenário teria menos cor. Para a história fica esta narrativa de imagens e de palavras que coincide com as Comemorações do $1^{\circ}$ Centenário da República. Que os nossos bisnetos, filhos dos filhos (no meu caso, do Rodolfo e da Susana) possam comemorar o Segundo Centenário com sabedoria poética e utopia inspiradora.

António Vilhena (Pai) 
(Página deixada propositadamente em branco) 


\section{Bibliografia}





\section{Bibliografia consultada}

\section{Documentos relativos à Associação:}

(1908), Relatório de Actividades da Associação de Escolas Móveis. Lisboa.

(1908), Associação de Escolas Móveis pelo Método de João de Deus, Bibliotecas ambulantes e Jardins-Escolas, Estatutos. Lisboa, Artigos 1. ${ }^{\circ}$ e n. ${ }^{\circ} 4$. Lisboa.

(1898), Associação de Escolas Móveis pelo Método João de Deus, A instrução do povo e o Método de João de Deus. Lisboa.

(1954), Jardins-Escolas João de Deus, Documentário da sua actividade. Lisboa.

(1956), Documentário da sua actividade. Jardins-Escolas João de Deus. Lisboa.

\section{Bibliografia geral}

Azevedo, Manuela de (1997), João de Deus Ramos. Vida e Obra. Lisboa.

Barros, João de (1911), “Jardim-Escola João de Deus”, in Boletim de Propaganda da Associação de Escolas Móveis pelo Método João de Deus nº (Abril-Junho). pp. 46-47.

Bergströn, G. Adolf (1912), "Jardim-Escola João de Deus”, in Boletim de Propaganda. Associação de Escolas Móveis. Bibliotecas ambulantes e JardinsEscolas $n^{\circ} 9$ (Julho-Setembro), pp. 91-95.

Brosque, G. (1950), "João de Deus Ramos”, in jornal Magazine da Mulher nº3 (Agosto), pp. 17-24.

Caldeira, M. Filomena (2009), Aprender a matemática de uma forma lúdica. Lisboa.

Campagnolo, H. (1979), João de Deus. Pedagogo Moderno. Lisboa.

Carvalho, Rómulo de (1981), História do Ensino em Portugal: desde a fundação da nacionalidade até ao regime de Salazar - Caetano. Lisboa.

Castro, Eugénio de Castro (1906), O Melhor Retrato de João de Deus. Lisboa.

Chá-Chá, C. Varela (2009), João de Deus. Dois Pedagogos. Uma obra. Lisboa.

Coelho, H. (2010), Trajectos do grés à arte da escrita (coord. G. Rocha Martins), Silves. 
Deus, João de (1878), Cartilha maternal ou Arte de Leitura.Lisboa.

(1881), A Cartilha Maternal e o Apostolado. Lisboa.

(1982), Campo de Flores, vols. I-II. Lisboa.

(1990), Amor Idílico. Aveiro.

(2002), Campo de Flores, Lisboa.

Figueira, M. Henrique (2003), Dicionário dos Educadores Portugueses (coord. A. Nóvoa). Lisboa, pp. 1151-1154.

(1986), Dicionário da Maçonaria Portuguesa. Vol II, Lisboa, col. 1193-1194.

Franco, J. E. (2009), “O Mito da Educação”, in C. Varela Chá-Chá, João de Deus. Dois Pedagogos. Uma obra. Lisboa, pp.13-19.

Lemos, Esther de, “Deus de Nogueira Ramos (João de)", + 2, pp. 70-75.

Levasseur, E. (1897), L’enseignement primaire dans les pays civilisés. Paris.

Marques, A. M. de Oliveira (1981), História de Portugal, vol. III (6 $6^{\mathrm{a}} \mathrm{ed}$.). Lisboa.

Mira, Ana Maria (1995), João de Deus e a actualidade do seu método ou Arte de Leitura. Lisboa.

Ramos, João de Deus (1902), Os altos princípios do Método João de Deus. Coimbra. (1907), "Jardins-Escolas ou Escolas Maternais", in Boletim das Escolas Móveis pelo Método João de Deus $\mathrm{n}^{\circ}$ 2, pp. 33-34.

(1920), Méthode J. de Deus. ABC Maternel Art de Lecture. Lisbonne.

(1943), "Brinquedos”, Boletim das Beiras S. 3, A.IX (Janeiro/Março), pp. 1315.

Ramos, M. da Luz de Deus (1962), "Oitenta anos ao serviço das primeiras letras”. Conferência proferida por ocasião da comemoração dos oitenta anos da fundação da Associação de Escolas Móveis pelo Método João de Deus (18 de Maio de 1882), texto policopiado. Museu João de Deus, Lisboa, pp. 1-9.

(1979) “João de Deus”, in Cadernos F.A.O.J. nº10, pp. 1-19.

(1982) "O Método Educativo João de Deus", apresentado no Encontro sobre Metodologia da Educação em Portugal, organizado pela Fundação Calouste Gulbenkian, texto policopiado, pp. 1-8.

(1997), "Testemunhos", in M. de Azevedo, João de Deus Ramos. Vida e Obra. Lisboa, pp. 35-43.

(1998), "Como nasceram e como podem morrer os Jardins-Escolas João de Deus”, Associação de Jardins-Escolas João de Deus (6 de Fevereiro), texto policopiado. Lisboa, p. 1-8. 
Raposo, N. de A. Vasconcelos (1991), O contributo do Método João de Deus para a Educação Pré-escolar. Lisboa.

Saraiva, Maria da Glória (2003), Práticas Educativas nos Jardins-Escolas João de Deus: estudo exploratório 1940-1989. Dissertação apresentada à Universidade do Minho, como requisito parcial para a obtenção do grau de Mestre da Educação, Instituto de Educação e Psicologia, Universidade do Minho.

Vasconcelos, C. Michäelis (1976), A Cartilha Portuguesa e em especial a do senhor João de Deus, separata da Revista Portuguesa de Pedagogia, Ano X, Lisboa.

\section{Sítio da internet}

Associação de Jardins Escolas João de Deus: http://www.joaodeus.com 


\section{A organizaÇÃo:}

Da esquerda para a direita

Ana C. Martins

Nelson Henrique S. F.

Ália Rodrigues

António Vilhena

Maria do Céu Fialho

Fernando Madeira

Teresa Madeira

Maria Amélia Saraiva 


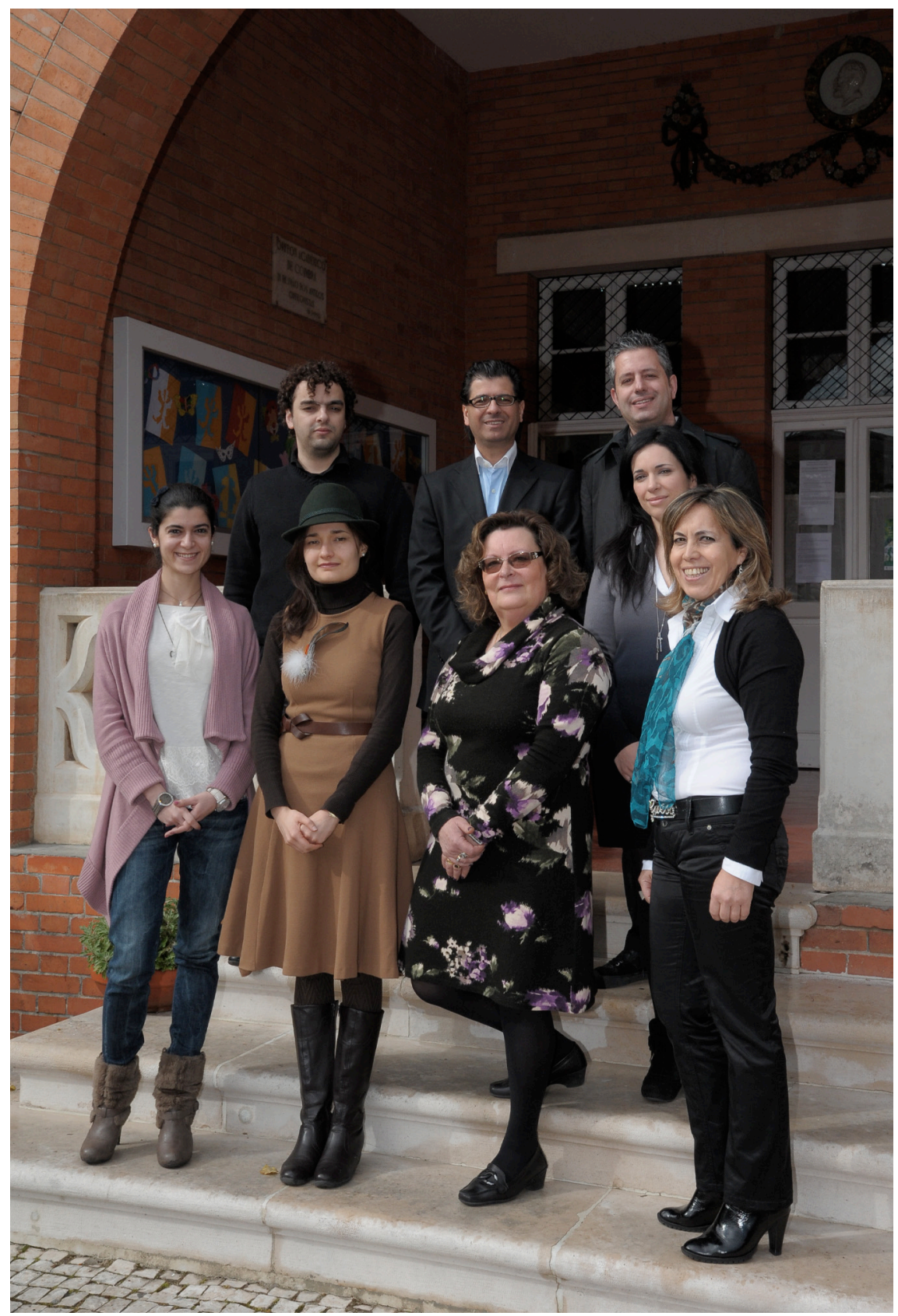




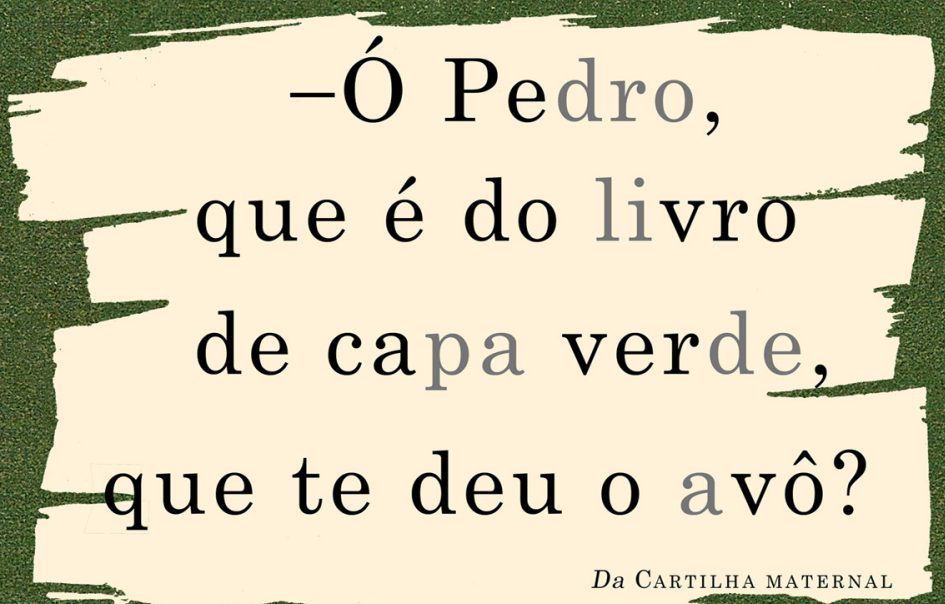

